IPOJUCAN PEREIRA DA SILVA

\title{
O Teatro Essencial de Denise Stoklos: caminhos para um sistema pessoal de atuação
}




\section{IPOJUCAN PEREIRA DA SILVA}

\section{O Teatro Essencial de Denise Stoklos: caminhos para um sistema pessoal de atuação}

Dissertação apresentada ao Programa de PósGraduação em Artes, Área de Concentração Artes Cênicas, Linha de Pesquisa Teoria e Prática do Teatro - Texto e Cena, da Escola de Comunicações e Artes da Universidade de São Paulo, como exigência parcial para a obtenção do Título de Mestre em Artes, sob a orientação do Prof. Dr. Felisberto Sabino da Costa.

São Paulo

2008 
BANCA EXAMINADORA 
A Deus, aos meus pais e aos meus amigos. 


\section{AGRADECIMENTOS}

Ao Prof. Dr. Orientador Felisberto Sabino da Costa, braço amigo de todas as etapas deste trabalho.

Aos amigos e colegas, pela força e pela vibração em relação a esta jornada.

Aos professores e colegas de Curso, pois juntos trilhamos uma etapa importante de nossas vidas.

Aos profissionais entrevistados, pela concessão de informações valiosas para a realização deste estudo.

A todos que, com boa intenção, colaboraram para a realização e finalização deste trabalho. 


\section{RESUMO}

Analisa as características do espetáculo solo no Teatro Essencial de Denise Stoklos, e investiga e organiza os processos de atuação solista do "performer essencial". Para a coleta dos dados: a) levanta-se por meio de pesquisa bibliográfica, audiovisual e dos espetáculos: os procedimentos de atuação performática, as características do espetáculo do tipo solo e as teorias sobre o Teatro Essencial; b) utilizam-se entrevistas qualitativas semi-orientadas, feitas com Denise Stoklos, três professores-assistentes e quatro alunos participantes do projeto Solos do Brasil, e um "performer essencial". Aponta como principais resultados: a) o "performer essencial" é o epicentro do acontecimento cênico; b) a exploração do potencial idiossincrático; c) os eixos principais são o corpo, a voz e a intuição; d) a autoria sob responsabilidade do atuante. Conclui que a dinâmica do processo de atuação solista imbrica-se com o cotidiano e leva o "performer essencial" a se manter num estado constante de autopercepção, captando os elementos que farão parte da dramaturgia espetacular e articulando ritmicamente o corpo e a voz para estimular o espectador à percepções diferenciadas.

Palavras-chave:Teatro Essencial. Denise Stoklos. Atuação. 


\begin{abstract}
It analyzes the features of the solo performance by Denise Stoklos in her concept of the "Essential Theater". It also investigates and organizes the processes of the soloist performance of the "essential performer". For the data collecting: a) by means of bibliographic research, audiovisual and the performances themselves: the procedures from the performing rendering, the characteristics from the solo performance and the theories about the "Essential Theater"; b) the use of semi-oriented qualitative interview including Denise Stoklos, three assistant teachers, and four students who participated in the project "Solos from Brazil", and 1 essential performer. Pointing out as the main results: a) the "essential performer" is the epicenter of the scenic happening; b) the exploration of the idiosyncratic potential; c) the most important axes are the body, the voice and the intuition; d) the performer has the responsibility for the autorship; It concludes that the dynamics of the process from the soloist performance imbricates with daily life, and leads the "essential performer" to be in a constant state of self-perception, capturing the elements which will be part of the dramatic acting and articulating rhythmically both body and voice to stimulate the spectator to differentiated perceptions.
\end{abstract}

Key-words: Essential Theater. Denise Stoklos. Performance. 


\title{
LISTA DE ABREVIATURAS
}

\author{
FSP Jornal Folha de São Paulo \\ FU Folha Universitária - UNIBAN \\ JB Jornal do Brasil \\ JT Jornal da Tarde \\ PJ Programa do Jô - TV Globo \\ OESP Jornal O Estado de São Paulo
}




\section{SUMÁRIO}

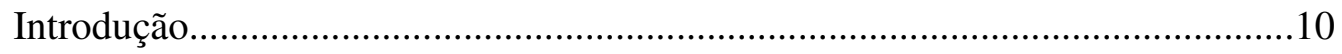

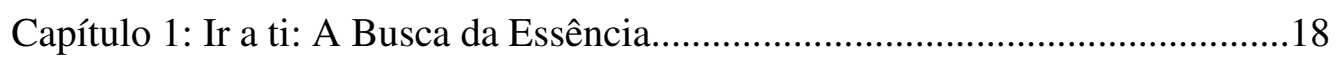

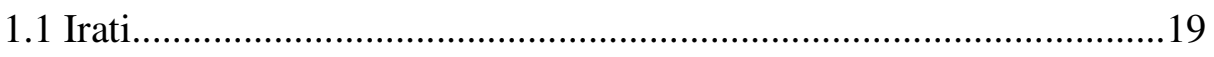

1.2 Década de 70: Teatro e Ditadura......................................................23

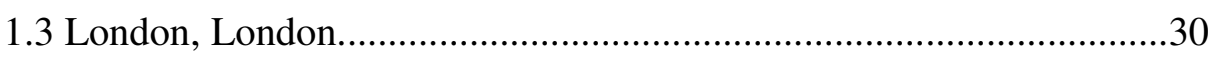

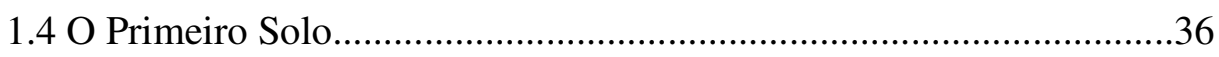

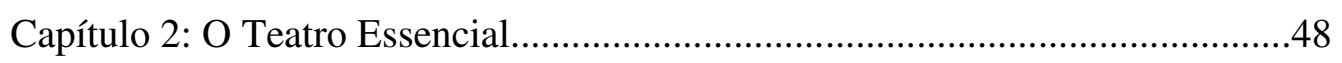

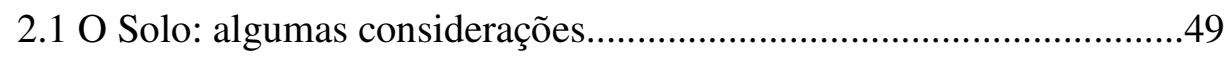

2.2 Uma Proposta Brasileira..................................................................53

2.3 Calendário, Mary Stuart e Casa............................................................63

2.4 “Solo Essencial”: Aspectos Dramatúrgicos.........................................79

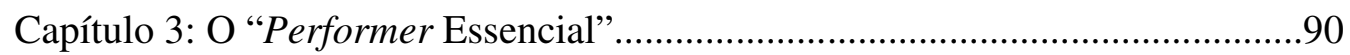

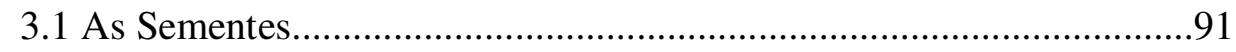

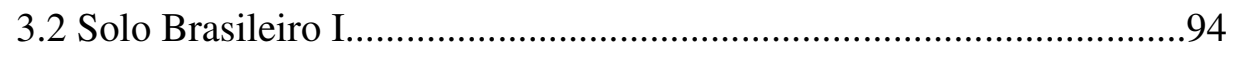

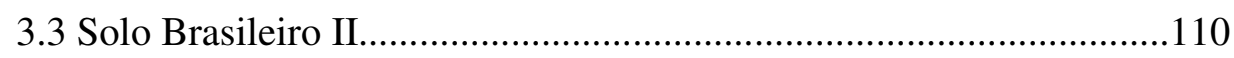

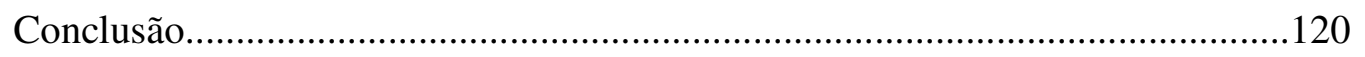

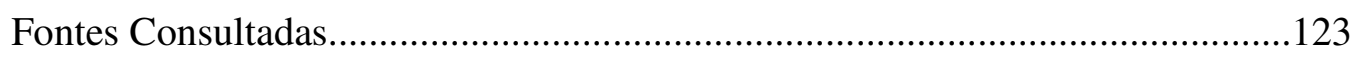

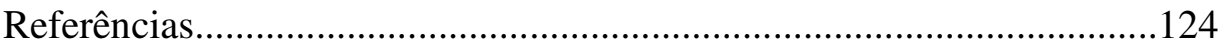

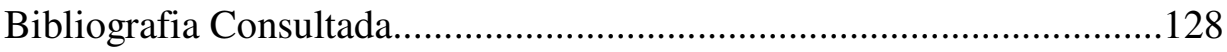

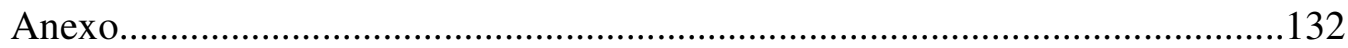


INTRODUÇÃO 


\section{Introducão}

Durante os meus estudos de graduação, tomei contato com algumas linguagens que faziam uso de uma maior plasticidade física e vocal do ator, tais como Clown, Commedia dell'Arte e Mímica, que despertaram o meu interesse para esse campo das artes cênicas. O resultado, ainda na graduação, foi o trabalho de Iniciação Científica A Revolução dos Bichos, uma adaptação dramatúrgica para o universo da máscara a partir do romance homônimo de George Orwell.

Ao optar por prosseguir meus estudos na pós-graduação, estava decidido a dar continuidade à exploração da linguagem da forma e do movimento por meio de máscaras e objetos, objetivando instrumentalizar melhor os atores no uso de seu potencial técnico. Contudo, antes mesmo de inscrever um projeto no programa de pós-graduação, aquela abordagem, que eu poderia chamar de "pré-histórica", evoluiu do interesse pelos processos de atuação causados pela modificação do estado corporal do ator por meio da máscara e do movimento, para os processos de atuação do performer, por meio de construção de personas ${ }^{1}$ responsáveis pela mediação e dinamização de sua presença cênica.

Oficialmente a Performance passa a ser aceita como um gênero artístico independente, no seio das artes visuais, no início da década de 70. Ela é o resultado de transformações ao longo do século XX que incorporaram as relações de tempo e espaço teatrais nas artes plásticas e as suas origens podem ser traçadas a partir tanto das ações demolidoras dos futuristas e dadaístas, quanto na Action Painting, no Happening e na Body Art que, com uma ação que se inicia nos anos 60, revolucionam os processos de produção e recepção da obra. Definir precisamente fronteiras para a Performance é sempre arriscado, devido à sua maleabilidade e indeterminação que rompe com convenções e restrições formais das categorias estabelecidas para o universo artístico.

\footnotetext{
${ }^{1}$ Para Renato Cohen, a persona diz respeito a algo mais universal, arquetípico e a personagem diz respeito a algo mais referencial. Segundo ele o trabalho do performer é de "levantar" a sua persona, o que geralmente se dá pela forma, de fora para dentro (COHEN, 1989, p. 103).
} 
Desde o seu surgimento, a Performance tem estado em permanente transformação, abarcando sempre novos elementos estéticos. A sua estrutura multimidiática lida com reproduções de imagens em movimento (vídeo, cinema, TV), informática, textos, música etc., contudo é o corpo do performer a sua mídia por excelência. Os artistas trocaram os materiais expressivos tradicionais, tais como tela, tinta e cinzel, pela materialidade dos próprios corpos, rompendo transgressoramente com o sistema de circulação de museus, galerias e colecionadores, que teria de esperar uma certa acomodação do gênero, no começo da década de 80, para conseguir seduzi-lo com apelos milionários.

As esculturas vivas de Gilbert e George, as performances relacionando corpo e espaço de Trisha Brown, os rituais sangrentos de Hermann Nitsh são exemplos de tais investigações corporais que confundem a distinção entre o criador e o objeto, já que ele mesmo é o suporte das suas intervenções. A variedade de ações que vão surgir daí são extensas e diferenciadas: das óperas monumentais de Robert Wilson às performances solo de Eric Bogosian, dos espetáculos sonoro-visuais de Laurie Anderson às punk performances no CBGB de Nova Iorque, do Butô de Sankai Juku à dança-teatro de Pina Bausch. Apesar de extremamente rica e instigante a pluralidade dessas manifestações espetaculares, uma genealogia da história da Performance fugiria do ponto inicial, gerador de toda pesquisa, que é a investigação dos processos de atuação performática.

Desse amplo universo fiz um recorte para o trabalho da atriz brasileira Denise Stoklos, objeto de estudo desta dissertação. Há anos ela desenvolve uma pesquisa de linguagem bastante singular em nossa cena teatral, denominada de Teatro Essencial. Os seus espetáculos, solos na maioria, baseiam-se na utilização de um mínimo de elementos cênicos e na exploração máxima do corpo e da voz do "performer essencial" (assim denominado o atuante no Teatro Essencial).

O teatro solista de Denise Stoklos exige do atuante o desempenho das funções necessárias para a realização do acontecimento teatral, estimulando-o a ir além das obrigações costumeiras de um ator, levando-o a acumular, na sua pessoa, a autoria, a criação, a execução e a responsabilidade do discurso cênico. Não sendo sua formação aquela de ator tradicional, propagadora de uma cultura academicamente estabelecida como 
de qualidade, seu teatro configura-se como um espaço descompromissado da veiculação de ideologias oficiais, aberto à experimentação, e com uma estrutura de produção autônoma.

O intuito desta pesquisa é analisar as características do espetáculo solo de Denise Stoklos, presentes na maior parte de toda sua produção, e também mapear os caminhos de sua atuação solista. Em virtude disso, nos concentraremos na fase de sua carreira que vai de 1979, por ser a data de estréia de seu primeiro solo, Denise Stoklos - One Woman Show, passando por 1987, data de lançamento do Manifesto do Teatro Essencial, até os dias atuais.O objetivo também deste estudo é diminuir a defasagem de pesquisas brasileiras sobre o Teatro Essencial, já que seu trabalho é tomado com regularidade como objeto de investigação em universidades na Inglaterra e Estado Unidos.

No primeiro capítulo, "Ir a ti: A Busca da Essência", por meio de dados colhidos em entrevista com Denise Stoklos e de um levantamento de informações encontradas em diversas publicações, foi feito um percurso histórico da sua carreira, englobando também as suas reminiscências infantis vividas na sua cidade natal, Irati. Mapeando a evolução dos elementos que constituirão seu Teatro Essencial, através dos convulsivos anos 70, no Brasil e no exterior, o final deste capítulo analisa os solos iniciais da trajetória profissional de Denise Stoklos.

O segundo capítulo, "O Teatro Essencial”, trata dos aspectos teóricos e práticos da linguagem desenvolvida por meio da experiência relatada no capítulo anterior. Os escritos, manifestos, reportagens, bem como as pesquisas sobre o tema, são empregados para organizar os princípios que regem a atuação no "solo essencial". As características espetaculares e dramatúrgicas foram analisadas com o mesmo intuito, por meio do contato com as apresentações e com filmagens. Quatro solos são objeto de estudo nesta parte: Denise Stoklos in Mary Stuart, Casa, Vozes Dissonantes e Calendário da Pedra.

O último capítulo, "O Performer Essencial”, traz as falas, pensamentos e experiências dos participantes do projeto Solo do Brasil e do "performer essencial" Marcos Americano, e busca compreender os processos deflagrados por Denise Stoklos na formação de atuantes segundo os princípios do Teatro Essencial. A pesquisa de campo foi realizada por meio de entrevistas e os depoimentos selecionados procuram traçar um quadro bastante expressivo dos caminhos apontados para um sistema pessoal de atuação solista. 


\section{Considerações sobre a Pesquisa de Campo.}

O método empregado para a obtenção dos dados foi a entrevista qualitativa, que nos ajudou na "compreensão das relações entre os atores sociais e o fenômeno, tendo como objetivo a compreensão detalhada das crenças, atitudes, valores e motivações, em relação aos comportamentos" (SILVA, 2006, p. 2, documento eletrônico), nos contextos nos quais esses indivíduos adquiriram as competências necessárias para formação de um performer essencial.

Optou-se por esse instrumento em vez de questionário, por ser avaliado como detentor de uma maior flexibilidade, "pois o entrevistador pode esclarecer o significado das perguntas e adaptar-se mais facilmente às pessoas e às circunstâncias nas quais se desenvolve a entrevista" (SILVA, 2006, p. 3, documento eletrônico), e por ser capaz de obter um maior número de informações, não só pelo conteúdo das respostas, como também pelo "silêncio [...], [pela] expressão corporal do entrevistado, [...] [pela] tonalidade de voz e a ênfase em algumas palavras ou expressões durante sua fala" (SILVA, 2006, p. 9, documento eletrônico). Tentou-se o emprego dos questionários, enviados eletronicamente, para os sujeitos não residentes no estado de São Paulo, contudo, além de não se obter resposta dos mesmos, houve dificuldade na compreensão da profundidade e extensão das perguntas.

O tipo de entrevista qualitativa escolhida foi a semi-orientada, também conhecida como semi-estruturada ou semi-dirigida, na qual, por meio de uma pauta ou roteiro, "o pesquisador de tempos em tempos efetua uma intervenção para situar o informante nos assuntos a serem investigados" (SILVA, 2006, p. 6, documento eletrônico), e o entrevistado tem liberdade de digressão a respeito da pauta colocada. É óbvio que se partiu do pressuposto de que todas as pessoas a serem pesquisadas eram capacitadas a fornecerem informações fidedignas, claras e coerentes com as experiências às quais foram submetidas nos contextos que vivenciaram. Um esclarecimento importante é que não se procurou estabelecer um distanciamento, buscando a neutralidade absoluta do ideal da objetividade científica entre sujeito e objeto, por dois motivos: já havia uma série de hipóteses levantadas por meio de outros materiais pesquisados, que direcionaram o trânsito das 
informações, e era importante a criação de um ambiente acolhedor e informal, que propiciasse a liberação dos medos e constrangimentos na relação entrevistador/entrevistado.

A entrevista feita com Denise Stoklos procurou obter um conjunto de dados que pudessem revelar dados da sua biografia, formação, espetáculos e teorias a respeito do Teatro Essencial.

A pesquisa realizada com os ex-participantes do projeto Solos do Brasil, apesar de não ser do tipo quantitativo, foi concretizada com aproximadamente um terço da equipe de docentes, constituída pela própria Denise Stoklos e por oito professores assistentes, e a mesma fração, também aproximada, da equipe de quinze alunos. As duas equipes estavam assim constituídas:

\begin{tabular}{|l|l|}
\hline \multicolumn{1}{|c|}{ Disciplinas ministradas } & \multicolumn{1}{c|}{ Professores assistentes } \\
\hline Direção & Gianni Ratto e Antonio Abujamra \\
\hline Mímica & Luís Louis \\
\hline Dança & Hugo Rodas \\
\hline Texto Corporal & Eduardo Coutinho \\
\hline Filosofia e Estética & Luiz Fuganti \\
\hline Canto & Caio Ferraz \\
\hline Teatro Dinâmico e Máscara Neutra & Ricardo Napoleão \\
\hline
\end{tabular}

\begin{tabular}{|c|c|}
\hline Alunos & Origem \\
\hline Cláudia D'Orey & Rio de Janeiro/RJ \\
\hline Danilo Souto Pinho & Fortaleza/CE \\
\hline Fábio Vidal & Salvador/BA \\
\hline Jaqueline Valdívia & Biguaçu/SC \\
\hline Jefferson Monteiro & São Paulo/SP \\
\hline Jô Rodrigues & São Paulo/SP \\
\hline Jorge Baía & Caruaru/PE \\
\hline Miguel Rocha & São Paulo/SP \\
\hline Roberto Salles & Salvador/BA \\
\hline
\end{tabular}




\begin{tabular}{|l|l|}
\hline Silvana Abreu & São Paulo/SP \\
\hline Sílvio Paulino dos Santos & Carapicuíba/SP \\
\hline Simone Faro & São Paulo/SP \\
\hline Taynã Azevedo & Belém/PA \\
\hline Tiche Vianna & Campinas/SP \\
\hline Vinícius Piedade & São Paulo/SP \\
\hline
\end{tabular}

Os entrevistados foram os professores assistentes Eduardo Coutinho, Luiz Fuganti e Ricardo Napoleão; e os alunos Jô Rodrigues, Simone Faro, Tiche Vianna e Vinícius Piedade. Foi realizada apenas uma única entrevista com cada um dos informantes, não ocorrendo nenhuma pesquisa em grupo, somente individual. Os tópicos do roteiro de questões foram padronizados para os dois grupos, havendo uma mudança no enfoque das perguntas. Aquelas destinadas aos alunos, levando-se em conta que as informações poderiam ser parciais e incompletas, procuraram em grande parte se referir a sua representatividade no grupo, a fim de se obter um conjunto equânime de dados que pudessem revelar os procedimentos comuns de formação do performer essencial. Aos professores, as questões foram formuladas esperando-se conseguir as diretrizes aplicadas por cada um que se coadunavam com os princípios do Teatro Essencial.

As perguntas feitas aos sujeitos giraram em torno dos seguintes tópicos: formação, processo de seleção, dinâmica das aulas, abordagem do tema geral, produto final, avaliação e bases do Teatro Essencial. Os dados colhidos constituem o item "Solo Brasileiro I", no qual optou-se por fazer "ecoar as vozes" dos entrevistados em torno de cada tópico, isto é, não são apresentadas súmulas das entrevistas de cada um, e sim, como numa espécie de "mesa-redonda", forma escolhidos trechos que melhor ilustravam o tópico em discussão.

Para o item "Solo Brasileiro II" o entrevistado foi Marcos Americano. Os objetivos, assim como o tipo de pesquisa, mantiveram-se idênticos. Pelas características diferenciadas das experiências do informante, além de ser-lhe dedicado um outro espaço dentro do capítulo, foram alterados alguns tópicos em relação aos aplicados nos ex-participantes do projeto Solos do Brasil. Neste caso elegeram-se cinco pontos: formação, histórico, treinamento, pedagogia e bases do Teatro Essencial. Também aqui se optou por escolherem-se trechos da entrevista que ilustrassem os tópicos abordados, porém com um 
aporte a mais: em alguns momentos, em busca de pontos de contato que universalizem os princípios de formação do "performer essencial", são evocados alguns trechos de entrevistas dos ex-participantes do projeto Solos do Brasil.

Para finalizar, cumpre ainda esclarecer que o registro das informações foi feito por meio de gravação direta, que se revelou bastante adequada, ao conferir poder de interação em tempo real ao entrevistador sobre a narrativa do informante. A análise feita posteriormente a cerca do registro sonoro traz inúmeras vantagens sobre o procedimento de anotação escrita, sendo mais inestimável a fixação da expressão oral do entrevistado, capaz de revelar um conteúdo latente que enriquece a exploração dos objetivos da pesquisa. Por se tratar de um material variado, que extrapola o recorte específico estabelecido para a análise, as informações consideradas relevantes, que esclareçam mais nitidamente algum ponto discutido, serão de alguma maneira contempladas ao logo da discussão que se segue. 
Capítulo 1

Ir a ti:

A Busca da Essência 


\section{$1.1 \underline{\text { Irati }}$}

Irati. Ir a ti. Pequena cidade do sul do Brasil onde nasci. Parece uma bacia, se diz. Parece sim, com aquelas montanhas ao redor do vale onde estão as casas. Da minha, eu via os campos de trigo lá longe e pensava: deve haver algo a mais, além daqui. (STOKLOS, 1992, p. 5).

A valorização de conteúdos autobiográficos é um dos principais eixos de uma "atuação performática", seja na reapresentação de memórias na forma de depoimentos ou na manipulação e transformação de episódios que fizeram parte da existência. Sem a distinção entre sujeito e objeto, arte e vida se misturam no corpo do atuante que, apoiandose na sua idiossincrasia, busca um vocabulário próprio para expressar a sua originalidade. Bem entendido aqui que autobiografia tem uma abrangência que vai além da narrativa a respeito de si mesmo, pois também se cria um espaço de discussão "para as minorias que não se enquadram na normatividade do discurso ideológico dominante" (BERNSTEIN, 2001, p. 92), quando o perfomer, ao se perscrutar, apresenta a sua resposta sensível às pressões sociais como forma de aumentar a conscientização do público.

O trabalho solista de Denise Stoklos tem início em 1980 com Denise Stoklos - One Woman Show, mas antes de tratarmos dos aspectos que configuram essa sua estrutura de produção, é de fundamental importância identificarmos alguns elementos na sua trajetória pessoal, ainda que rudimentares, que não só evoluirão como estarão sempre presentes na conformação de seus espetáculos.

De ascendência ucraniana, Stoklos nasceu em 1950 na pequena cidade de Irati, interior do Paraná, e iniciou a sua carreira de atriz profissional em Curitiba, em 1968, com a peça Círculo na Lua Lama na Rua, junto ao seu grupo teatral, o Ferramente, no qual foi autora, diretora, cenógrafa e atriz. Até esse momento, as suas experiências com teatro estavam ligadas à infância e adolescência vividas na sua cidade natal, que ela própria define como formadoras do seu estilo de atuação:

Pra eu fazer teatro original, sem copiar, sem reproduzir, fazer no teatro aquilo que me inspirava, dentro de mim, sem ter nenhuma expectativa de reproduzir um teatro, ah, eu sou uma atriz beckttiana, sou uma atriz brechtiana, sou uma atriz 
grotowiskiana... Não, eu era uma atriz iratiana [...] Não veio de nenhuma cultura, não foi porque eu entendi, tive uma possibilidade de compreender Stanislavski [...] Não, não tinha isso. Não tinha nenhuma linha para seguir. A não ser aquilo que tinha dentro de mim [...] se você vai buscar dentro de você o que vem é presença. O que se chama talvez de carisma, de certa forma, mas é porque você está integrado com você [...] $\mathrm{O}$ ator entrou, então tem um conteúdo assim que aparece porque ele está cheio de si mesmo, das suas histórias, das suas indagações (STOKLOS, entrevista, grifo nosso).

É reveladora a função que o material autobiográfico assume na constituição do seu fazer. Diferente de outros performers solo, tais como os americanos Spalding Gray, nos seus monólogos, quase jornalísticos, recheados de trechos da sua biografia, e Karen Finley, nos relatos pessoais que misturam ficção e realidade, o contexto de vida é empregado principalmente para a criação de uma linguagem única e para alicerçar um estado cênico que garante a enunciação do discurso a ser proferido.

Ao alinhar a existência de Irati às poéticas de grandes realizadores das artes cênicas no Ocidente, todas as suas ações artísticas passam a ser resultado das interações sofridas naquele ambiente. Nas reminiscências infantis já se faz presente o interesse por gêneros artísticos que despontarão mais tarde na constituição dos seus solos, já que a ausência de um teatro "tradicional" na cidade a fez conviver durante toda a infância com o cinema e o circo. Do mundo circense, ela localiza nas brincadeiras infantis, as primeiras idéias do uso audacioso do corpo de maneira espetacular: "Tinha uma barra na casa do meu vizinho, a gente fazia de tudo ali naquela barra e montava muito circo no depósito da minha casa" (apud NÉSPOLI, 16/03/1999, p. D 6). Já os filmes da Atlântida representaram para si a “escola brasileira dos grandes atores comediantes... Derci Gonçalves, Mazzaropi, Zé Trindade, Zezé Macedo, Oscarito ” (FU, 21 a 26/08/2006, p. 4).

\footnotetext{
No início do século XX, a aproximação entre circo e teatro foi muito evidente. Basta lembrarmos de Meyerhold, na Rússia, o qual propôs que na formação do ator fossem desenvolvidos movimentos circenses como acrobacias e malabarismo [...] No Brasil, em 1918, o palhaço negro Benjamim de Oliveira no circo Spinelli, criou o circo-teatro [...] O circo-teatro consistia numa primeira parte de circo com os números normais e em uma segunda parte com a representação de um espetáculo normalmente melodramático com o clássico trio: galã, mocinha e vilão (apud DUARTE, 1995, p. 203; GÓIS, 2005, p. 71; apud RUIZ, 1987, p. 29).
}

Mesmo considerando a inexistência de um espaço especificamente destinado às apresentações teatrais em sua cidade, com certeza ela teve contato com os melodramas 
apresentados em circos-teatro, tão comuns na época, e obviamente com o conteúdo acrobático, as bufonarias dos palhaços, a música e a plasticidade vibrantes. Pode-se inferir também que o circo, com a sua estrutura narrativa disposta em quadros, composta basicamente pela encenação, provavelmente estimularam a sua compreensão da arte cênica pelo viés das habilidades físicas demonstradas pelo atuante, foco principal de atenção para a platéia.

Esses artistas, formados na prática da sua atividade, fundamentada num tipo de atuação da estética do excesso e do exagero, calcada nos personagens-tipo, na mecânica do efeito cênico e na ação propriamente dita, podiam também ser encontrados nas chanchadas nacionais em cartaz no cinema local. Aliás, alguns deles eram egressos do circo e vários do Teatro de Revista, outro gênero de espetáculo de variedades, também estruturado como uma sucessão de quadros que comentam a realidade cotidiana, recheados de música, dança, humor, alegria e sensualidade.

De forma lúdica ela também exercitava esse fazer no internato onde estudava, imitando os professores, os padres e as freiras para as colegas ou, segundo ela própria: “em casa, inventava uma coisa que eu queria comunicar, montava lá do meu jeito e apresentava para os amigos, para quem quisesse ver" (apud NÉSPOLI, 16/03/1999, p. D 6).

Lançando um olhar ao passado, aos primeiros anos da sua vida, Stoklos pondera: "todos esses atores dos dois lados [circo e cinema] me mostravam que eram autodidatas, que o encontro deles com sua arte de representação não dependia de nenhuma escola. E da mesma forma isso ocorreu para mim também" (STOKLOS, entrevista). O curioso, contudo é que a maioria desses artistas não era um autodidata, apenas não tinham uma formação regulamentada por um currículo escolar. $\mathrm{O}$ seu aprendizado se dava na transmissão prática e direta entre um profissional mais experiente e o aprendiz, seja por imitação ou observação, e o instrumento de aferição do sucesso desse ensino era a aprovação do público. Esta sempre foi a grande "escola" dos atores populares.

Errônea ou não, o que há de mais revelador por trás desse pensamento é a idéia de que era possível constituir uma prática se valendo do conhecimento pessoal; prática essa originalíssima por si só, já que não seria decorrente de nenhum saber constituído previamente. Na sua estréia profissional, essa crença no autodidatismo levou-a a praticamente desempenhar todas as funções relativas à encenação para que o texto da sua 
autoria, Círculo na Lua Lama na Rua, fosse posto em cena. O conteúdo autobiográfico imprimiu sua marca, assegurando a fé no potencial pessoal, definindo um estilo, uma linguagem. Como observa RoseLee Goldberg, a respeito das performances de Julia Heyward: "[Ela] cresceu nos estados do Sul, filha de um pastor presbiteriano. Traços dessa formação subsistiam em seu estilo e no conteúdo de suas performances, bem como em sua atitude diante da própria performance" (GOLDBERG, 2006, p. 162).

Irati sempre se fará presente, acessada como uma consciência atemporal, evocando as relações familiares, o ambiente da comunidade, o cotidiano feito dessas lúdicas explorações e desafios. Retornaremos, assim como ela, a esse ponto quando se fizer necessário, verificando como esses elementos foram ganhando outras roupagens e manifestações nas escolhas artísticas, nos caminhos trilhados, nas recusas e proposições; e principalmente: como fazem parte da criação de seus solos, da constituição do trabalho do atuante e da concepção de seu Teatro Essencial. 


\subsection{Década de 70: Teatro e Ditadura}

Em 1968, em Curitiba, na época da estréia de Círculo na Lua Lama na Rua, Denise Stoklos estava matriculada nos cursos universitários de Ciências Sociais, na Pontifícia Universidade Católica do Paraná - PUC/PR, e Jornalismo, na Universidade Federal do Paraná - UFPR. A sua crença de que ela já continha em si mesma todas as ferramentas necessárias ao fazer teatral, levaram-na a escolher uma formação superior diferenciada das artes cênicas. Ela chegou a freqüentar durante quase um ano um curso, no Teatro Guaíra, que acabou abandonando, segundo o seu depoimento, por não concordar com a grade curricular: "não gostava das aulas teóricas, eu não entendia que teatro era daquele jeito [...] É que eu não me encontrava com aquele tipo de trabalho, onde o diretor e o ator servem a um escritor que já bolou como vai ser" (STOKLOS, entrevista).

Guiada pelo firme propósito de que o ator é centro do acontecimento teatral, continuou junto ao seu grupo escrevendo, dirigindo, produzindo e atuando nas suas outras produções, tais como: A Semana (1969); Vejo o Sol (1970); Mar Doce Prisão (1971) e Cadillac de Prata (1973). Nota-se que o seu pensamento se aproxima do artista preconizado por Adolphe Appia ${ }^{2}$ que desempenharia as funções de autor e encenador, como também das concepções do ator-criador de Etienne Decroux ${ }^{3}$, e de outros renovadores da cena, que no século XX procuraram investir o intérprete de uma participação maior na criação do espetáculo.

Um outro passo em sua carreira foi aceitar o convite de um dos diretores mais experientes de Curitiba, Oraci Gemba, para trabalhar como atriz em montagens locais de peças como Arena Conta Zumbi e Arena Conta Tiradentes, originalmente encenadas pelo Teatro de Arena de São Paulo. O espaço proporcionado por esse diretor era concordante com o tipo de formação desejada por ela, isto é, com maior liberdade para o ator e eminentemente prática. Um outro aspecto valorizado é que Oraci Gemba deu os primeiros direcionamentos para um trabalho corporal cênico a partir do que ela propunha:

\footnotetext{
2 Adolphe Appia (1862-1928), cenógrafo suíço que atribuiu à luz uma tarefa que até então o teatro não fizera, ou seja, criar espaço, produzindo profundidade e distância.

Considerado o pai da Mímica Moderna, Decroux começou sua carreira em 1923 na Ecole du Vieux Colombier, sob a direção de Jacques Copeau, e em 1941 abriu sua própria escola de mímica corporal.
} 
Oracir Gemba, que foi assistir essa minha primeira peça [...] me chamou para trabalhar no grupo dele, onde ele me dava um espaço muito grande [...] Tinha muito corpo no teatro dele [...] Aí fiz três peças com ele onde tudo o que eu fazia de movimento, eu era muito física, eu fazia o movimento e ele adorava a movimentação (STOKLOS, entrevista).

É importante observar que a opção pelos estudos nas áreas de Comunicação e Sociologia não estava desvinculada de um sentido utilitário, procurado por ela nas suas próprias peças. Círculo na Lua Lama na Rua, por exemplo, tratava do tema da maisvalia, fruto obviamente das discussões que permeavam aquele momento político de ditadura militar e, segundo ela, a formação universitária acabou lhe rendendo ferramentas para um melhor ajuste dos vetores de seu discurso cênico:

Na minha cidade, Irati, o diretor do jornalzinho local, quando viu que eu escrevia, disse: "Vamos publicar no jornal, porque quem escreve precisa publicar, [...] passa a ser um acontecimento social [...] E depois que está publicado [...] você é responsável por aquilo que você está dizendo, é uma comunicação com quantas pessoas que vão ler aquilo" [...]

O Jornalismo então tinha também esse caráter para mim, [...] de que você está sendo um arauto de um fato, da comunidade para a comunidade [...] E portanto ter uma resposta que tivesse alguma interferência nos movimentos sociais.

Aí entra as Ciências Sociais, também me dando um certo estofo para compreender estes movimentos, vindo a contar muito para compreender ou tentar entender em que grupo social eu estava metida [...]

Tudo isso foi me situando e me dando uma compreensão de que meu teatro deveria ser o que se chama de engajado, isto é, que respondesse imediatamente ao que todos nós estávamos motivados, mobilizados, portanto um teatro político (STOKLOS, entrevista).

Novamente desponta a importância das experiências pessoais nas escolhas dos caminhos do fazer artístico. Cada vez mais esse cultivo em afinar os conteúdos internos às solicitações do momento atual vai se tornar uma das dinâmicas principais do seu teatro, que tentará sempre expressar no individual as pulsões da coletividade. E a resposta dela naquele instante com Círculo na Lua Lama na Rua, refere-se aos anseios políticos que pairavam na sociedade da época.

A carreira profissional de Denise Stoklos se iniciou exatamente no ano em que o governo militar assinou o Ato Institucional $\mathrm{N}^{\mathrm{o}} 5$ (AI-5), que deu ao então presidente, o general Costa e Silva e a seus sucessores, poderes absolutos. A agitação principalmente dos jovens parece ter assustado a ditadura, que resolveu sufocar qualquer indício de 
contestação. Depois do AI-5, as prisões se multiplicaram, as torturas se intensificaram e as execuções secretas se tornaram uma prática comum. A década de 1970 foi o período mais repressivo após o golpe dos militares.

O levante dos estudantes em Paris, em maio de 68, que culminou numa greve geral contra o governo conservador do general Charles De Gaulle, revelou essa geração como uma força de transformação histórica, eclodindo num clima de contestação permanente que, de um modo geral, passou a envolver a juventude da Europa, E.U.A. e América Latina. No Brasil, mesmo em uma época de intensa repressão, os estudantes brasileiros unidos e conscientes dos seus direitos e da sua força, se fizeram ouvir por meio dos diretórios, das manifestações e das passeatas, como a memorável Passeata dos Cem Mil, em junho de 68, que ocupou as ruas do centro do Rio de Janeiro.

Este talvez tenha sido o ano mais difícil para o teatro brasileiro. A censura se tornou tão incomodamente presente no cotidiano dos artistas, que os teatros do Rio e de São Paulo declararam-se em greve, em protestos pelas ruas e vigílias nas portas dos estabelecimentos teatrais das duas cidades. A tensão chegou ao auge quando o Comando de Caça aos Comunistas invadiu, em São Paulo, o espaço onde estava em cartaz a peça Roda Viva, de Chico Buarque, espancando e maltratando vários membros do elenco, destruindo o cenário e o equipamento técnico.

No ano de 1973, Stoklos muda-se de Curitiba para o Rio de Janeiro, onde presta testes e integra o elenco da remontagem da peça Missa Leiga, de Chico de Assis, sob a direção de Adhemar Guerra. No ano seguinte, participa em São Paulo da seleção de atores para a peça Bonitinha, mas Ordinária, de Nelson Rodrigues, a segunda experiência do diretor Antunes Filho com a obra do grande dramaturgo brasileiro (a primeira foi $\mathbf{A}$ Falecida, em 1965). Com Antunes nesse momento, ela entra em contato com as experimentações que ele vinha empreendendo desde 1971, quando da montagem de Peer Gynt, de Ibsen, de recusar a linguagem realista e de se aproximar cada vez mais do fantástico, do expressionismo e da plasticidade corporal.

$\mathrm{O}$ ambiente cultural naquele momento corresponde ao período mais fechado e autoritário do regime militar. O então presidente Médici, o general de "linha dura", governava por meio de decretos-leis, apoiando-se quase que exclusivamente no Conselho de Segurança Nacional, cercado e protegido pelo AI - 5. No final do seu mandato a maioria 
das organizações de resistência esquerdista haviam sido desbaratadas, o que o leva a declarar que agora sim o Brasil era uma "ilha de tranqüilidade".

Para sobreviver nessa "ilha de tranqüilidade", só era tolerado o chamado "teatro digestivo, que não ameaçava o regime, e que, pelo contrário, ajudava-o a se sustentar dentro da filosofia do "pão e circo"” (LEVI, 1997, p. 46). Em contrapartida, após a extinção das vozes contestadoras mais expressivas, o Arena, em 1971, o Oficina, em 1973, e o Opinião 1979, esta ação do governo também provocou uma resposta mais acirrada da facção dos artistas politizados, que foram responsáveis por manter um “" "teatro de resistência”, que procurava criticar a repressão desencadeada pela ditadura militar substituindo as referências explícitas à situação do país por metáforas atemporais” (FERNANDES, 2000, p. 22), como meio de burlar as perseguições e a censura.

Experimentos com novos caminhos para a encenação procuravam dar conta de substituir a palavra censurada, o que ocasionou uma maior relevância do uso do corpo (dança, expressão corporal), da sensorialidade, das imagens, do subjetivismo. Um dos desenvolvimentos mais interessantes do teatro brasileiro nos anos 70 foi a aproximação da intenção política com a pesquisa de linguagem. Esse apoio da cena numa maior teatralidade, e por conseguinte na fisicalidade do ator, vinha ao encontro da maneira expressiva de atuar de Stoklos, corroborando dessa forma com a visão do fazer teatral adquirida na infância, em Irati, constituída do contato com o circo e com as chanchadas. Em 1976, ainda em São Paulo, ela trabalhou em Sai de Mim Tinhoso, uma colagem de textos de Bertolt Brecht dirigida por Luis Antônio Martinez Corrêa, na qual Cacá Rosset fazia assistência de direção. E pelo comentário da crítica, podemos perceber que essa escolha estava afinada com a sua idiossincrasia:

\footnotetext{
Daí trabalhei com Luiz Antônio Martinez Corrêa, irmão do Zé Celso, que fazia um teatro muito brechtiano. [...] Trabalhei numa peça extremamente expressionista. A Ilka Zannoto disse: "Denise Stoklos, a mais expressionista das atrizes brasileiras!" Eu tinha 24 anos e era expressionista sim, os movimentos grandes, as mãos enormes, as caras... e eu tenho essa identificação (STOKLOS, entrevista).
}

Em 1977, ela participa de Um Ponto de Luz, direção de Fauzi Arap, com a Royal Bexiga's Company, um grupo formado por jovens atores que enfeixava uma vertente que vinha, desde o início da década, buscando uma maneira muito própria de ser e atuar, se 
valendo para isso do improviso, da espontaneidade, da irreverência, de uma aguda observação do cotidiano que resultavam numa revigorada estética cênica.

No dia 10 de julho de 1974, estréia em São Paulo [...] O que você vai ser quando crescer? Nos créditos da produção, a marca que se transformaria em tendência no decorrer da década de 70: "criação coletiva do Royal Bexiga's Company", um grupo cooperativado de teatro (FERNANDES, 2000, p. 21, grifo do autor).

Além da Royal Bexiga's Company, outros importantes grupos articulavam-se como equipes de criação cooperativadas, tais como o Pessoal do Vitor, o Ventoforte, o Teatro do Ornitorrinco, o Pod Minoga e o Asdrúbal Trouxe o Trombone, tanto no que diz respeito à divisão de recursos quanto à divisão de funções e papéis, investindo principalmente nos processos de criação coletiva.

\footnotetext{
Nessa perspectiva, o texto nasce, ao mesmo tempo que o espetáculo, do próprio corpo e da voz do ator que procura, freqüentemente às cegas, o seu personagem. A improvisação, é bom frisar, não se apóia exclusivamente na memória e na espontaneidade individuais. Ela utiliza também o trampolim da reflexão coletiva, da leitura de textos documentários, históricos, etc (ROUBINE, 1998, p. 74, grifo do autor).
}

Este trabalho se afinava estreitamente com o espírito da contracultura presente na época, uma outra forma de contestação assumida pela juventude, na qual o confronto se dava pela recusa às formas de organização social e pela ameaça à moral vigente. $\mathrm{O}$ sentido de produção comunitária, que socializa as relações laborais e de convivência, desdobra-se no interior dos grupos teatrais. Um exemplo disso foi o grupo estadunidense Living Theatre, "uma comunidade itinerante que procura expressar-se teatralmente e agir sobre o público" (ASLAN, 1994, p. 279), que em visita ao grupo Oficina, no começo da década, deixou marcas profundas quanto aos seus modos de criação e de existência.

Neste processo o individualismo do ator dá lugar a uma participação criadora por parte de todos os integrantes, pulverizando a hierarquia tradicional na qual o diretor concebia a montagem e o elenco a concretizava. Tomando como ponto de partida a si mesmo na busca da personagem, por meio do improviso, o intérprete mistura muito dos seus conteúdos pessoais aos ficcionais, confundindo a distinção entre ambas as instâncias.

Apesar do fértil panorama das pesquisas de linguagens, o ano de 1977 é um momento de impasse na carreira de Stoklos. Até então ela já havia trabalhado em diversas 
peças do teatro profissional, com uma ótima repercussão na imprensa dos seus trabalhos. Também já tinha tido algumas experiências nos teleteatros da TV Cultura, onde, entre outros diretores, conheceu Antônio Abujamra, encontro que ainda renderia grandes parcerias, fruto principalmente da grande admiração que nutre pelo seu estilo de direção e pela sua mestria. Contudo, segundo a sua avaliação, as opções se tornavam cada vez mais escassas: "estava cansada daquela situação que ninguém podia nem se reunir [...] era um desânimo muito grande pela situação política [...] O meu caminho de desenvolvimento seria me tornar uma atriz de novela, mas esse eu não queria" (STOKLOS, entrevista).

Assim, ela e o marido (de ascendência judaica) decidem sair do país ao conseguirem duas bolsas de estudos, em Sociologia e em Psicologia, respectivamente, para fazer mestrado na Universidade de Jerusalém. O objetivo, na verdade, não era estudar e sim sair do país, numa espécie de exílio voluntário. Já grávida ao sair do Brasil, Stoklos viveu alguns meses num kibutz, depois foi para a África do Sul, seguindo para a Alemanha, até chegar no começo do ano seguinte, em 1978, à Inglaterra. Em Londres, onde nasce sua primeira filha, ela permanecerá dois anos e se dedicará ao estudo da mímica, do clown e da acrobacia. Enquanto isso, no Brasil, em dezembro de 78, foi revogado o AI-5.

O contexto brasileiro dos anos 70 representou na sua trajetória a exploração, a expansão e o amadurecimento das experimentações artísticas da infância e da adolescência. Já exibindo na sua gestualidade física traços de uma expressividade espetacular, conseqüência de um entendimento intuitivo adquirido no contato com a arte circense e os gêneros de caráter "ligeiro", as suas opções sempre foram em busca de uma afinação do seu instrumental nas passagens que realizou pelos vários diretores e grupos. Ao invés de desprezar esta bagagem "original”, em detrimento da aquisição de novos conhecimentos, o seu movimento foi o de justamente promover um refinamento no seu modo de operar.

A situação sócio-política deu sentido aos estudos jornalísticos e sociológicos, municiando-a de ferramentas investigativas que seriam repetidamente empregadas na análise da realidade cotidiana e na estruturação de uma linguagem que procuraria ser o arauto das inquietações humanas. Os "anos de chumbo" deixaram ainda as suas marcas na compreensão do engajamento necessário que o teatro deve ter no tratamento dos seus temas, do seu espaço, dos seres que povoam seus domínios. 
O começo do exercício da função de encenadora de seus próprios textos, submerso ao longo da década, eclipsado pelo trabalho de atriz, retornará agora nesses próximos anos de especialização no exterior. Movimento constante no seu fazer artístico, no qual, como rios subterrâneos que jorram em nascentes, os conteúdos pessoais e autobiográficos renascem constantemente metamorfoseados em novas temáticas. Acompanharemos a partir de agora, na sua passagem pelo ambiente londrino, as reverberações e suas consequiências que a aproximam cada vez mais da constituição de uma linguagem própria. 


\title{
1.3 London, London
}

\begin{abstract}
Abri o Time Out e tinha lá dois cursos naquela ocasião: tinha um com a Glenda Jackson de interpretação e outro de mímica. Eu pensei: "Bom, aprender o teatro inglês não vai me servir muito para o Brasil, agora aprender mais um pouco a disciplina do corpo é uma coisa universal, vai ser legal!" (PJ, 17/03/2007).
\end{abstract}

Em 1979, em Londres, Denise Stoklos fez uma especialização técnica em mímica em uma das mais conceituadas escolas da Inglaterra, a Desmond Jones School of Mime. O seu diretor, Desmond Jones, discípulo de Etienne Decroux, pertence à geração de artistas que, a partir da década de 70, passaram a unir o corpo, a voz e a criação na figura do atorcriador $^{4}$, num movimento chamado de Teatro Físico ou Mímica Contemporânea. O atorcriador seria aquele que participa ativamente de todos os momentos do processo de criação artística, acumulando autoria, e que fundamenta esse processo numa dramaturgia física (corpo e voz), pressupondo a participação do público.

\begin{abstract}
[Decroux] Explorou a idéia do corpo dilatado que potencializa a presença do ator e a percepção do espectador, o equilíbrio precário, em oposição ao modo de se movimentar natural, e enfatizou as tensões e a energia de cada movimento a fim de vivificar sua presença. Aprofundou-se nos estudos das articulações e contrapesos (físicos e morais); desenvolveu uma complexa gramática corporal [...] introduziu conceitos importantes como [...] espasmos (impulsos), movimentos isolados [...] Um importante achado foi a decodificação dos movimentos do pensamento no corpo (LOUIS, 2005, p. 30).
\end{abstract}

Os ensinamentos de Decroux estão na base desta prática do Teatro Físico. Ele desenvolveu uma técnica corporal que tem como objetivo colocar aspectos subjetivos dentro do movimento, ampliando as possibilidades expressivas do corpo, situando-o como principal meio de expressão. Sem querer se restringir à mímica objetiva da pantomima, na qual os gestos praticamente substituem as palavras e o gestual está mais preocupado com os

$4 \quad$ A figura do ator-criador talvez seja a marca registrada do Teatro Físico, principalmente devido à diversidade dos artistas abarcados por esse gênero, tais como, atores, bailarinos, performeres, mímicos e clowns. 
aspectos ilustrativos, a Mímica Corporal estuda detalhadamente o movimento e aplica-lhe os princípios fundamentais do drama.

O instinto investigador que leva Stoklos a estudar uma linguagem pouco explorada no seu país de origem, encontra eco também no fascínio que o circo exercia no seu imaginário infantil. A mímica, assim como esse, lida com desafios físicos de superação corporal, excitantes na mesma medida para a imaginação do espectador. O contexto teatral vivido até então no Brasil, da criação a partir das suas idiossincrasias, estimula o aprimoramento das possibilidades expressivas, sem contar na possibilidade de aplicação na cena teatral brasileira desse conhecimento de construção espetacular, centrada na corporalidade do intérprete.

Foram três meses de aulas intensivas na Desmond Jones School of Mime. Nesse ínterim, uma colega de curso a convidou para que prestassem um teste para um grupo de teatro experimental feminino, o Beryl \& The Perils, que trabalhava com criação coletiva. $\mathrm{O}$ espaço de improviso, encontrado por Stoklos ao trabalhar com esse grupo, fez nascer uma pesquisa de exploração pessoal das possibilidades sonoras do uso da voz, quando ela teve de atuar em outro idioma que não o seu. Essa investigação virá a se tornar uma marca registrada dos seus futuros trabalhos e será nomeada de "coreografia da palavra", da qual trataremos no próximo capítulo. Ao terminar o curso de mímica, junto com duas outras colegas, ela cria seu próprio grupo de teatro, Three Women, cujo primeiro espetáculo, High Heels, reunia uma série de esquetes de mímica desenvolvidas durante o curso e outras criadas especialmente para a montagem.

Stoklos admite que alguns princípios destes estudos de Mímica Contemporânea são constantes nos seus espetáculos até hoje. Um deles, por exemplo, é o do Isolamento Articular, que consiste em movimentar uma única articulação óssea mantendo o ponto fixo na outra articulação relacionada ao movimento que se deseja produzir. Um outro é o do Espasmo, que consiste na recusa em iniciar e parar o movimento, causando uma espécie de "soluço", resultando na precisão, clareza e limpeza do gesto.

Mantendo sua participação nos dois grupos, excursionou por várias cidades da Inglaterra e por diversos países europeus, apresentando Is Dennis Really the Menace? e Nuts com o Beryl \& The Perils, e High Heels com o Three Women. Foi durante uma dessas tournées que surgiu o estímulo à criação do seu primeiro solo, vindo de um mímico 
belga, que ao vê-la em cena a aconselhou a montar um espetáculo como solista. Esse tipo de atuação, também conhecida como Performance Solo, começou a se tornar muito popular nessa época, principalmente nos clubes nova-iorquinos, onde artistas performáticos tais como Eric Bogosian, Karen Finley e Spalding Gray se valiam do humor, da sátira, do comentário social ou de relatos autobiográficos. RoseLee Goldberg conclui que as ações desses performers "ajudaram a criar e a difundir um novo gênero: o cabaré artístico" (2006, p. 181).

O local de estréia do primeiro solo da sua carreira, intitulado Denise Stoklos - One Woman Show, foi no Women's Arts Alliance, em Londres, onde ela ministrava workshops de mímica. Logo em seguida, em conseqüência de um convite do British Arts Council, excursionou com sua performance por todo o Reino Unido. O espetáculo combinava teatro, dança e mímica em dez esquetes que giravam em torno, predominantemente, da condição da mulher numa sociedade machista:
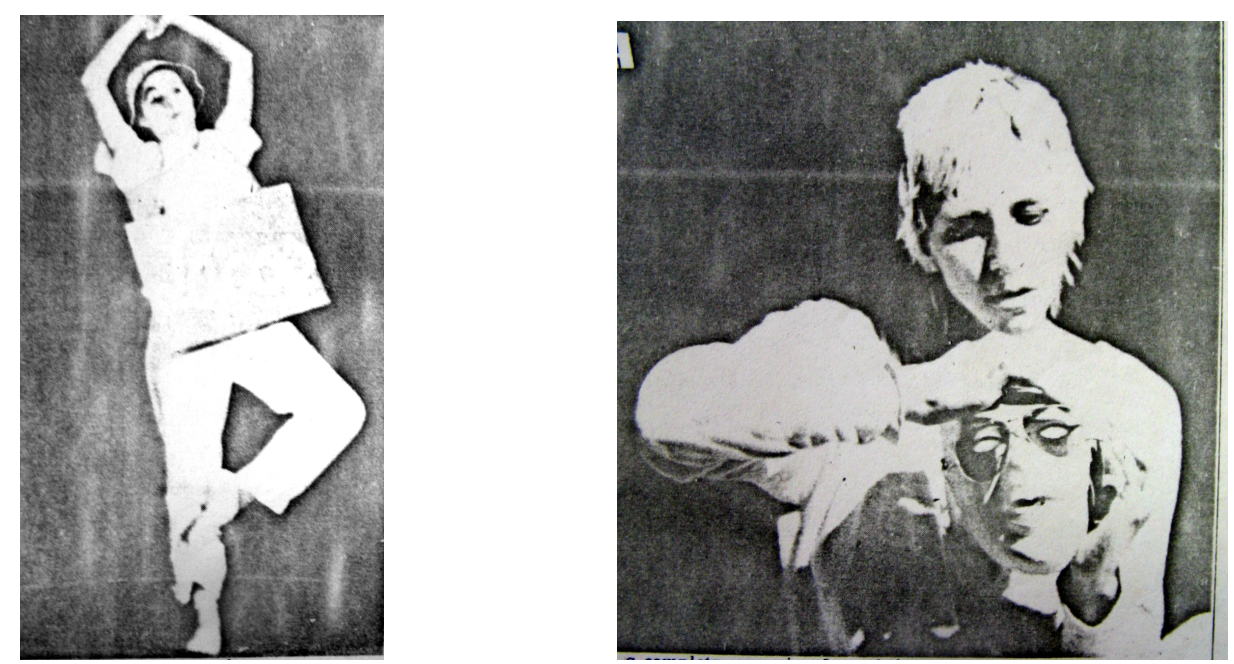

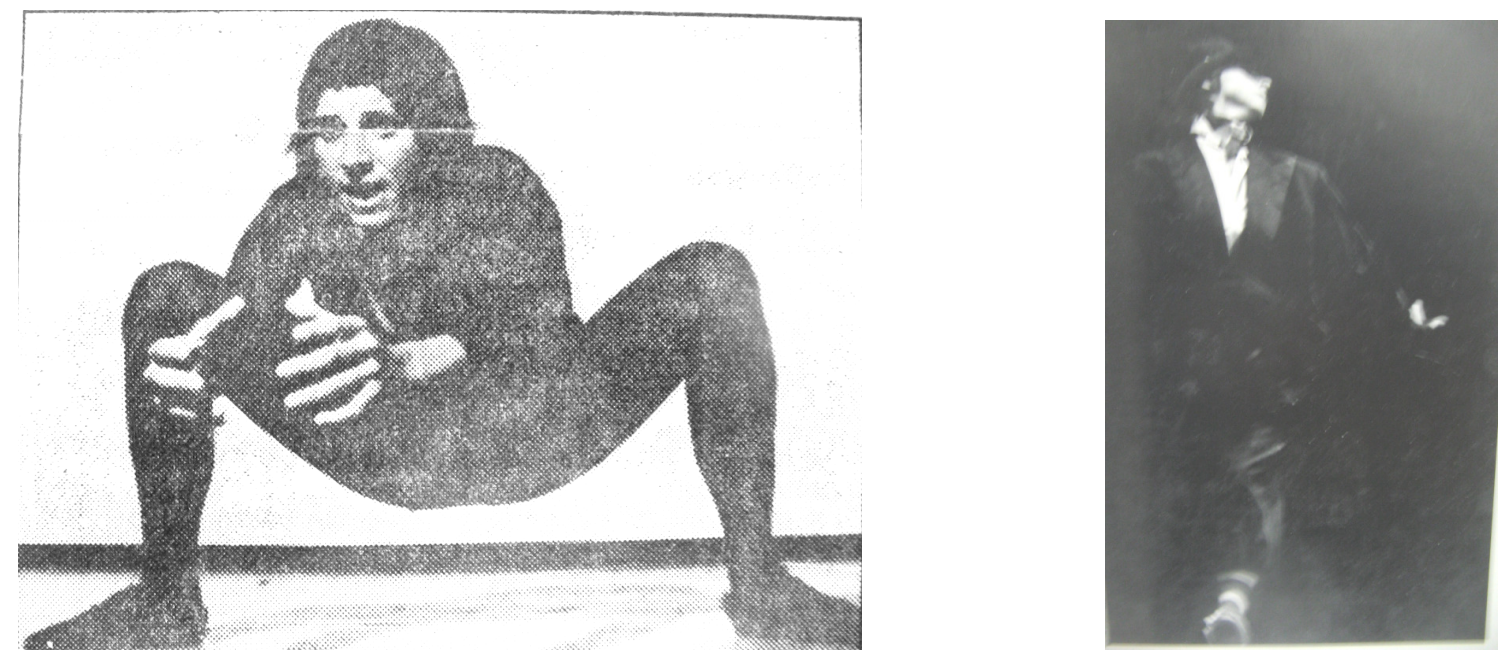

A sua opção por abordar o tema, com o objetivo de desconstruir lugares-comuns, deve-se muito ao ambiente europeu em que ela estava imersa. Com o amadurecimento do movimento feminista a partir dos anos 60/70, as discussões relativas às questões de gênero, no ambiente da arte européia e americana, começaram a ganhar destaque e protagonismo. A partir da idéia de que o gênero é um exercício, uma ação, um comportamento, e não algo inerente ao ser, as performances de gênero passaram a desafiar e relativizar as normatizações do masculino e do feminino.

A estrutura narrativa do espetáculo remete-nos novamente a tradição do circo e da revista, organizada em quadros com variadas atrações, diferindo aqui, no caso, que esta multiplicidade estava a cargo da habilidade de um único atuante, muito parecido também com o artista popular que se apresenta nas feiras e praças públicas.

Grávida do segundo filho, ela é obrigada a ser substituída nos espetáculos que tomava parte nos grupos Beryl \& The Perils e Three Women, restringindo-se apenas às apresentações do seu solo. A gravidez também interrompeu o curso de acrobacia que vinha freqüentando com Eugenio Bala. Próximo ao fim da gestação, em junho de 1980, ela decide por um fim ao seu exílio voluntário e retornar ao Brasil, que a partir de 1979 tinha iniciado o processo da abertura política, com o fim do bipartidarismo e a anistia aos exilados pelo regime militar. O partido do governo, ARENA (Aliança Renovadora Nacional), e o oposicionista, MDB (Movimento Democrático Brasileiro), enfrentavam dissidências internas. 
A reforma partidária culminou em 1982 com as eleições diretas para governador. Em 1984, com a criação da campanha "Diretas Já", que assumiu proporções gigantescas, ganhando as ruas e as praças, a contribuição da participação das massas na mudança do regime político nacional ocasionou o surgimento da "Nova República", em 1985, que pôs fim aos vinte anos de vigência da ditadura, com a eleição de Tancredo Neves pelo Colégio Eleitoral.

A anistia significou a chance dos exilados políticos voltarem ao país para retomar uma trajetória interrompida. O resgate da identidade e a possibilidade de recomeço correspondia a um investimento renovado nos projetos e nos sonhos abandonados. Num primeiro momento eles se afiguram para a nação, que necessitava de uma versão oficial sobre os anos de cassação, como a rememoração de uma lembrança perdida.

\footnotetext{
[...] sentimentos de estranhamento, desenraizamento, perda e crise de identidade e luto, (são) típicos do exílio. Ao mesmo tempo, se o desenraizamento pode trazer - e freqüentemente traz - conflitos identitários, por outro lado também pode criar um campo onde o exilado circula em liberdade, conecta-se com outras culturas, possibilitando novas descobertas, vivências e experiências diversificadas, aprendizado em termos de idiomas, costumes, etc (CRUZ, 1999, p. 33).
}

No processo de reintegração, os relatos das suas experiências, mais do que a transmissão da experiência individual, funcionam como um artifício de reconstrução de um contexto identitário esfacelado. Buscando obliterar lacunas, tanto o sujeito quanto a coletividade submergem num processo que, se em princípio parece salutar, pode vir a ser certamente doloroso em alguns momentos. Se por um lado, ao serem postos à parte do curso histórico dos seus conterrâneos, isso os coloca numa situação de liminaridade, por outro a situação também contribui para tornar suas identidades menos fixas e unificadas, e portanto permeáveis ao ambiente diverso.

$\mathrm{Na}$ assimilação dessas pessoas, as novas referências trazidas em seus corpos, em seus costumes e em seus pensamentos entrava em choque com universo brasileiro. A aceitação, ou mesmo a troca de significados, representava tanto uma poderosa fonte criativa, produzindo novas identidades e novas formas de cultura, como podia assinalar uma certa indeterminação, uma perda de referenciais.

Diferentemente de alguns outros exilados, que ao se sentirem deslocados na cultura que os acolheu, fechavam-se em guetos como forma de manter intacta as suas identidades, 
sub-existindo numa espécie de limbo, Stoklos se dispôs aberta à permeabilidade e às trocas com o meio. Como vimos, ela não só estudou como trabalhou e participou da vida social e cultural britânicas. $\mathrm{O}$ visual moderno adquirido em Londres com que ela aportará no Brasil - cabelos louros, descoloridos, quase brancos, espetados para o alto à moda punk - virá a se tornar sua marca registrada e o índice de contemporaneidade de seu teatro.

Não se pode também negligenciar que a experiência possibilitada pela estrutura do espetáculo solo, acenava como uma alternativa bastante eficaz de produção e expressão no meio teatral brasileiro, que quando da sua partida, estava sujeito às constantes flutuações resultantes da intervenção do Estado. Na realidade experienciada por ela quando deixou o país, apostar numa produção cara era correr os riscos da inviabilização pela censura. Além do mais, a opção pela ausência da palavra também pode ser vista como um ato político: o que não foi dito nunca existiu. A expressão silenciosa e solitária do corpo do solista, num momento em que os agrupamentos eram coibidos, propiciava uma articulação mais efetiva de um ato de contestação e resistência, tomando de volta o espaço que os "anos de chumbo" calaram e extinguiram.

A temática feminina deste primeiro solo será recorrente em sua produção, com o corpo passando a ter um lugar de destaque nos procedimentos de performatização. As narrativas biográficas somar-se-ão aos relatos centrados nas questões de gênero, levando as reivindicações também para as discussões de singularidade identitária. O pensamento individual será assim instado a se manifestar como um eco do coletivo, tornando-se o principal território onde os discursos buscam a expressividade e a emancipação.

Veremos então como todas essas imbricações vão ganhar espaço junto aos conteúdos até aqui explanados. Cabe também ressaltar que este solo foi a retomada da autoria na sua carreira e que como veremos será intensificada daqui por diante em seu fazer artístico. 


\subsection{O Primeiro Solo.}

Em 1981 acontece a reestréia de Denise Stoklos - One Woman Show na sala Assobradado do TBC, em São Paulo, mantendo o mesmo programa das apresentações feitas em Londres, no ano anterior. Ao passo que Sábato Magaldi, com um acurado olhar, já identifica que a "linguagem de Denise é pessoal, distante das propostas de Marcel Marceau [...] Daí o interesse que sua contribuição poderá assumir, no futuro" (1981, p. 20), Yan Michalski observa que a atriz que ela se revela neste primeiro solo:

\footnotetext{
“[...] é de uma técnica segura e variada. Gestos nítidos, precisos, desenhados com elegância; um domínio do corpo baseado em profunda musicalidade, que permite extrair efeitos surpreendentes desse fundamento da gramática da mímica que é a variação rítmica; um rosto expressivo e versátil, capaz de mutações” (1982, p. 2).
}

Apesar das críticas elogiosas, o espetáculo ficou apenas um mês em cartaz. A lotação do teatro variava entre 15 a 20 pessoas e Stoklos avaliou que o desinteresse do público brasileiro, ao contrário do inglês, era devido ao seu desconhecimento da linguagem, já que, como observa: "aqui a maior parte das pessoas não sabe o que é mímica ou pantomima" (FSP, 03/08/1982, p. 32). Pode-se agregar também que mesmo com o amparo solidário da imprensa, conferindo uma imagem heróica ao processo de reinserção dos exilados naquele momento, não se estava livre do choque entre alteridades.

A saída encontrada foi excursionar por várias capitais brasileiras com Denise Stoklos - One Woman Show, por aproximadamente dois anos, em temporadas curtas, ou em apresentações esporádicas em eventos. Não foi por falta de oportunidades de trabalho a escolha desta itinerância, já que não faltaram convites para uma reintegração ao cotidiano teatral. Atender a estes acenos, porém, implicaria num direcionamento da carreira a partir do ponto deixado para trás, quando da saída do país, ou seja, contentar-se em desempenhar, praticamente, apenas a função de atriz nas estruturas tradicionais de produção naquele momento.

As experiências no exterior acabaram por moldar uma identidade diferenciada, que clamava pela busca de outras inserções no ambiente cultural. A necessidade de afirmação leva-a a ostentar o rótulo de mímica, mas ao longo dos anos sua atitude será "camaleônica", 
sempre tornando impreciso um termo adequado que defina o seu fazer teatral. Na verdade essa ação despistativa, aparentemente premeditada, traduz um movimento de impermanência consigo mesma, um constante devir, de transformar a vida num processo artístico constante.

Para ganhar então uma maior visibilidade como uma das poucas mímicas em atividade no país, ela passa a ministrar cursos e workshops em espaços diversos e no seu próprio estúdio, aberto em São Paulo. Numa matéria publicada nesse período, Helena Katz reconhece a importância de seu esforço pelo trabalho de divulgação e formação de mímicos na cidade:

\begin{abstract}
Denise vem apresentando solos desde de sua volta ao Brasil. A primeira vez que participou de um espetáculo coletivo foi com "Maldição", espetáculo que criou com seus alunos [...] Só o fato de estar nascendo um grupo de mímica em São Paulo já justifica uma ida ao teatro [...] Porque é importante que tomemos conhecimento dos progressos que a mímica, enquanto técnica corporal, vem realizando nestas últimas décadas (KATZ, 1983, p. 27).
\end{abstract}

Algumas personalidades ligadas à linguagem da mímica atualmente, tais como Fernando Vieira, Denise Namura e Eduardo Coutinho, freqüentaram as aulas de Denise Stoklos. Estas estratégias acabaram também por lhe render bons frutos pessoais, ao participar de uma novela e de comerciais para a TV, que auxiliaram ainda mais na consolidação de uma imagem, que ainda hoje é difícil de se desvencilhar.

Neste sentido o espetáculo do tipo solo era uma alternativa bastante satisfatória para as suas ambições, já que era possível fazer alterações na estrutura de acordo com o tipo de público ou espaço, minimizar os custos de produção e centralizar as decisões. Ao expressar o seu temor para com esta tomada de decisão, de criar um nicho para si, interessantes são as palavras de Yan Michalski a esse respeito: "O que me aflige um pouco é pensar qual o espaço de trabalho que ela encontrará no Brasil, fora da evidentemente limitada e facilmente esgotável fórmula de recital individual" (1982, p. 2).

Um outro passo de fundamental importância na trajetória de desenvolvimento de uma linguagem pessoal ficou por conta do contato estabelecido em 1982 com Leonard Pitt 5 .

\footnotetext{
$5 \quad$ Mímico de formação clássica que estudou três anos com Étienne Decroux, em Paris, tendo
} posteriormente se especializado em teatro balinês com um dos mestres, na própria ilha de Bali, por dois anos. 
Com a intenção de fazer um curso de reciclagem de um mês e meio, que incluía mímica e teatro balinês, ela foi a São Francisco tomar aulas na Leonard Pitt's School:

\begin{abstract}
Quando eu estudei mímica [...] Os exercícios levavam a conclusão de uma convenção gestual. Por exemplo, você faz horas de exercícios de espasmos, de isolamento para chegar a abrir uma porta [...] O mímico em si não está vendo aqueles objetos e sim está ocupado em trabalhar a tensão aqui, o peso ali [...] Para mim essa linguagem desse jeito é muito limitada porque se refere apenas a descrição de uma ação [...] falta uma participação crítica do artista que está realizando, ele não está interessado em mostrar o que ele acha daquela parede. Ele só está interessado em construir uma parede perfeita aos olhos do outro [...] Eu quero é um passo adiante disso [...] que aquele virtuosismo não apareça mais porque foi apenas um veículo para aquele encontro do público consigo mesmo. Então, para isso [...] eu fui fazer aquele outro curso com Leonard Pitt (MOURA, 1998, anexo, p.1).
\end{abstract}

Na sua escola, Pitt já introduzira outras práticas no treinamento da mímica, baseadas na desconstrução do gestual cotidiano, na tentativa de eliminar a distância entre o pensar e o fazer, para que os impulsos encontrassem uma resposta direta na ação física. Essa postura era uma preocupação da geração dos mímicos contemporâneos, após o passo dado pela Mímica Moderna em criar uma técnica codificada. Nas suas investigações o trabalho com as máscaras do Teatro Balinês auxiliava-o na busca por uma expressividade corporal menos premeditada pelo atuante.

Pitt, que já a tinha assistido no seu solo, propôs laboratórios de pesquisa individual para que assim ela pudesse receber a orientação necessária, alegando que ela estava escondida "atrás" da mímica e que era necessário "jogar fora" a linguagem e se abrir aos estímulos. Nessas sessões o principal objetivo era quebrar, distorcer, romper o virtuosismo do gesto, limpando o corpo dos códigos da mímica, para que aparecesse a opinião do ator, a sua essência expressiva, sobre aquele mesmo gesto. A dinâmica era introduzir na trajetória gestual, de um ponto a outro do espaço, a errância e a indeterminação por meio da repetição automatizada desse trajeto, levando a um certo grau de exaustão. A intenção é que surjam outras direções para a movimentação a partir das indicações do próprio corpo e não de uma concepção prévia. Esse processo de ir "desconstruindo/construindo/desconstruindo" a gestualidade também era aplicada à fala, pois o corpo é visto aqui como uma unidade que integra o físico, a voz e o pensamento. 


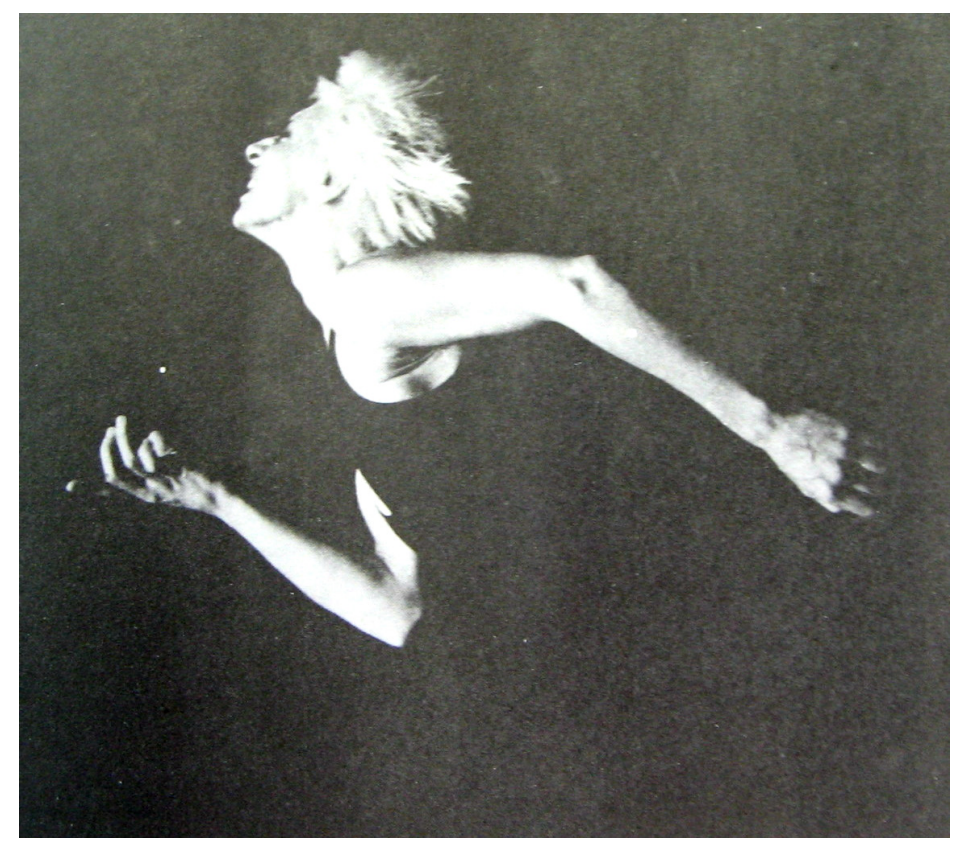

Elis Regina

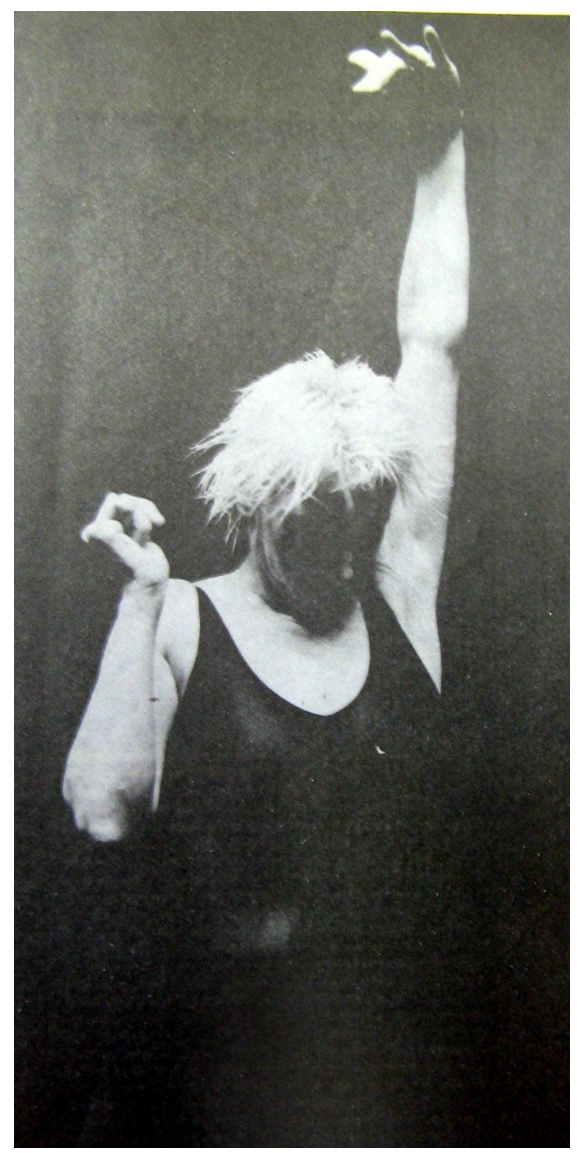

Elis Regina 
Segundo uma declaração sua quando retornou dos Estados Unidos, Stoklos planejava montar um espetáculo cujo tema era a sua cidade natal: "A vontade de realizar "Irati” apareceu lá longe, na Califórnia, neste trabalho que desenvolvi agora. De repente foram as minhas raízes que apareceram" (apud KATZ, 09/11/1982, p. 37). Ao que tudo indica, a preocupação em diluir a rigidez da técnica para dar passagem a expressão de conteúdos mais profundos a colocaram em contato com as suas memórias, ou seja, para encontrar o caminho que a leve a estruturação de uma linguagem única e pessoal, para ser um "atriz iratiana", a resposta estava na sua autobiografia. A latência desse projeto vai encontrar apoio para sua expressão somente em 1988, com estréia do solo Hamlet em Irati.

No fim daquele mesmo ano de 1982, ela estreava Elis Regina, uma homenagem póstuma à cantora recém-falecida, que nessa primeira versão, e na segunda, ainda contava com a participação de um ator em cena, alcançando na terceira versão, em 1986, o formato definitivo, no qual ela era a única presença em cena. Esse segundo solo de sua carreira já apresenta a incorporação dos estudos com Leonard Pitt: variações rítmicas, espontaneidade e improvisação, que virão a se constituir em fundamentos importantes na composição técnica de seus solos.

Elis Regina era a transposição gestual para o palco das músicas interpretadas pela cantora, que ganhava a expressividade do corpo de Stoklos em cena. Às vezes fazendo a mímica descritiva do que dizia uma letra (como na música O Primeiro Jornal de Sueli Costa e Abel Silva), ou, em outros momentos, executando partituras coreográficas, ela se abstinha do uso da própria voz para que Elis se fizesse recordar. É interessante observar que no quadro dedicado à canção Deus lhe Pague de Chico Buarque, ela se utiliza de um dos recursos tradicionais mímica, a parede imaginária, para representar um cubículo que acaba por esmagá-la, como uma metáfora da opressão e aprisionamento do ser humano, uma imagem recorrente nos seus solos.

Com estas novas diretrizes, em 1983 é encenado um dos grandes sucessos de sua carreira, que traria reconhecimento nacional ao seu trabalho: Um Orgasmo Adulto Escapa do Zoológico (do original italiano Tutta Casa, Letto e Chiesa, de Dario Fo e Franca Rame), com direção de Antônio Abujamra, e a participação especial de um ator na representação das figuras masculinas. 


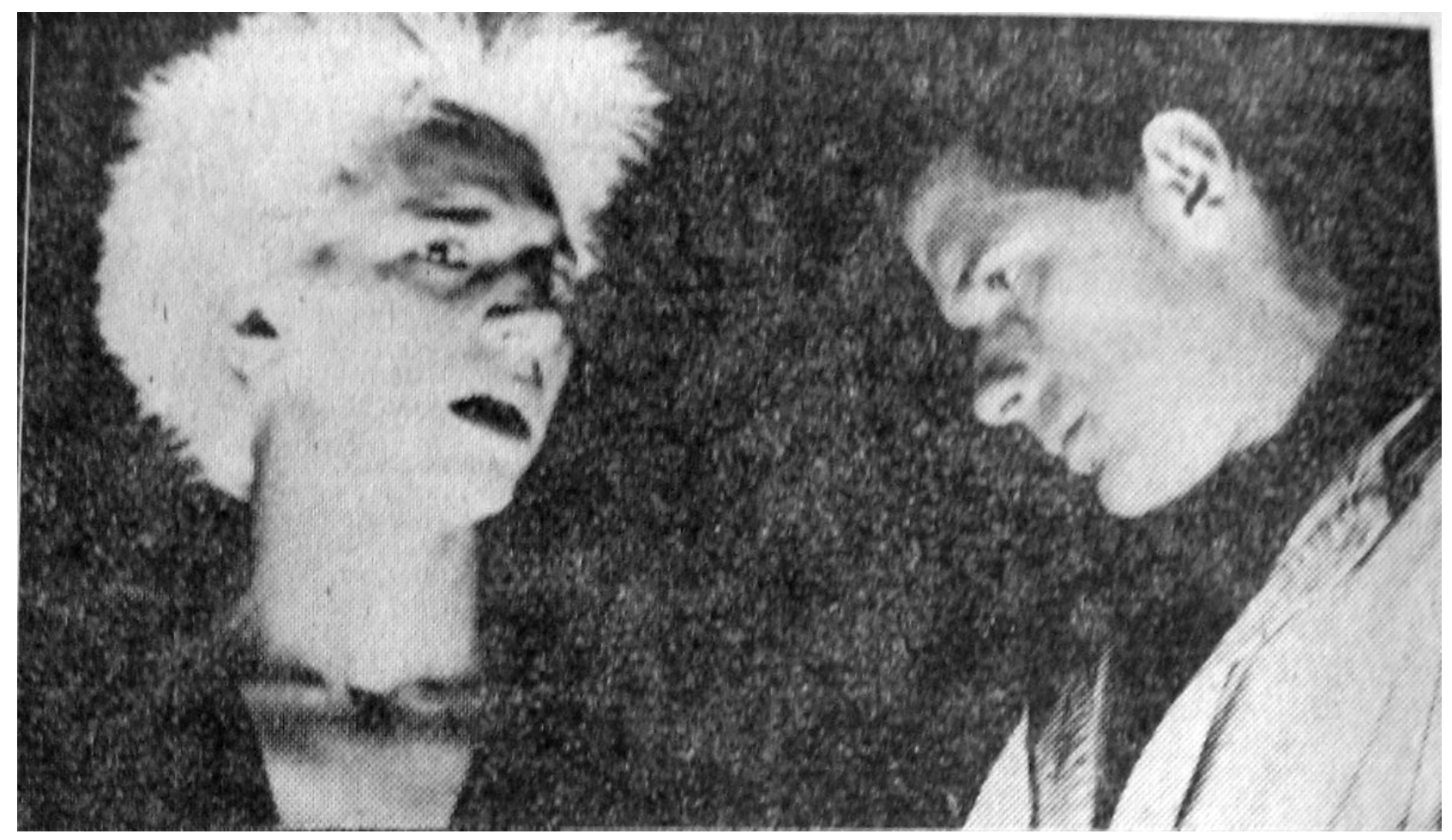

Denise Stoklos e Miguel Magno em Um Orgasmo Adulto Escapa do Zoológico 
Desde o seu retorno ao Brasil em 1981, essa foi a primeira vez que Stoklos fez uso da palavra em cena e que experimentou a aplicação da sua pesquisa técnica a um texto dramático pronto. No curso realizado na Califórnia ela já havia experimentado o emprego do gesto e da palavra de uma forma desassociada, como objetivo de que a movimentação corporal não fosse a tradução do discurso falado, abrindo assim possibilidades a um mergulho maior na sonoridade da voz, sendo mais um item a ser somado na estruturação da sua "coreografia da palavra". Mais tarde, esse procedimento de desconstrução vocal será nomeado de "defacetar", uma derivação da palavra inglesa deface $e^{6}$.

O texto original, apresentado a ela pelo diretor Antônio Abujamra, é composto por nove monólogos que tratam de uma forma tragicômica a situação de opressão de vários tipos de mulheres, que de alguma forma lutam pela sua liberdade. Com a parceria proposta por ele, o resultado do casamento do trabalho gestual de Stoklos com literatura dramática foi bastante satisfatório.

Os dois escolheram e traduziram quatro dos nove monólogos de Tutta Casa, Letto e Chiesa: Temos Todas a Mesma História; Uma Mulher Só; Eu, Ulrike Meinhoff e Um Orgasmo Adulto Escapa do Zoológico, sendo o nome deste último escolhido para dar o título à montagem. $\mathrm{O}$ terceiro monólogo, baseado na carta escrita na prisão pela terrorista alemã Ulrike Meinhoff, era o momento trágico da peça que fazia um contraponto às situações cômicas de confinamento doméstico feminino enfrentadas pelas outras personagens. A temática da discussão do papel da mulher na sociedade, que Stoklos já havia abordado no seu primeiro solo, se desdobrava e agregava outro conteúdo: a clara intenção de dar voz aos presos políticos revela um processo de rever as suas experiências relativas a esse contexto. Tais questões irão evoluir e reaparecer muitas vezes nos espetáculos futuros, caracterizando a temática do confinamento feminino como um ponto de discussão recorrente.

Houve um encadeamento, onde o Abú me deixou fazer como eu queria, como eu entendia. Me lembro que um dia ele chamou o cenógrafo pra ver, pra fazer o cenário. Eu estava ensaiando, fazia uma mulher numa janela que falava com a vizinha: "Aí eu pego a espingarda, não sei o que...!" Aí o Abu dizia assim: "Tá vendo? Ela precisa de uma janela."

E o cenógrafo dizia: "Mas não precisa, eu vejo a janela quando ela faz o gesto!"

6 Deformar, desfigurar 
"Ah, tá bom! Ali, viu que ela pegou uma espingarda? Precisa pendurar uma espingarda!"

"Mas não precisa, eu vejo que ela pegou uma espingarda!"

Então assim, o cenógrafo foi olhando e tirando o cenário dele, não pondo, e deixando que o meu cenário aparecesse, que eram os meus gestos. Então virou um fundo infinito, era uma coisa de madeira, como se fosse um lugar para fotografar, onde apareciam os meus movimentos bem recortados (STOKLOS, entrevista).

A predileção por estruturas de produção teatral que dão liberdade de ação ao ator, manifestada desde os tempos em que foi dirigida por Oraci Gemba, torna-se extremamente presente nas suas escolhas profissionais. As experiências pretéritas com criação coletiva e os processos autorais de seus solos apontam para a importância conferida ao atuante na constituição de sua linguagem pessoal. O papel do diretor, do cenógrafo e de outros profissionais envolvidos é de colaboração, numa relação muito mais horizontal, do que verticalmente hierarquizada, de auxílio à mise-en-scène proposta pelo intérprete. Mesmo embrionário, já despontam procedimentos concernentes à encenação, que se tornarão marcas registradas do seu fazer teatral: a idéia de um repertório que é continuamente reconfigurado, a dramaturgia criada em ação e centrada no corpo e no espaço, a autodireção, as parcerias de colaboração, a substituição dos elementos cênicos pela gestualidade física:
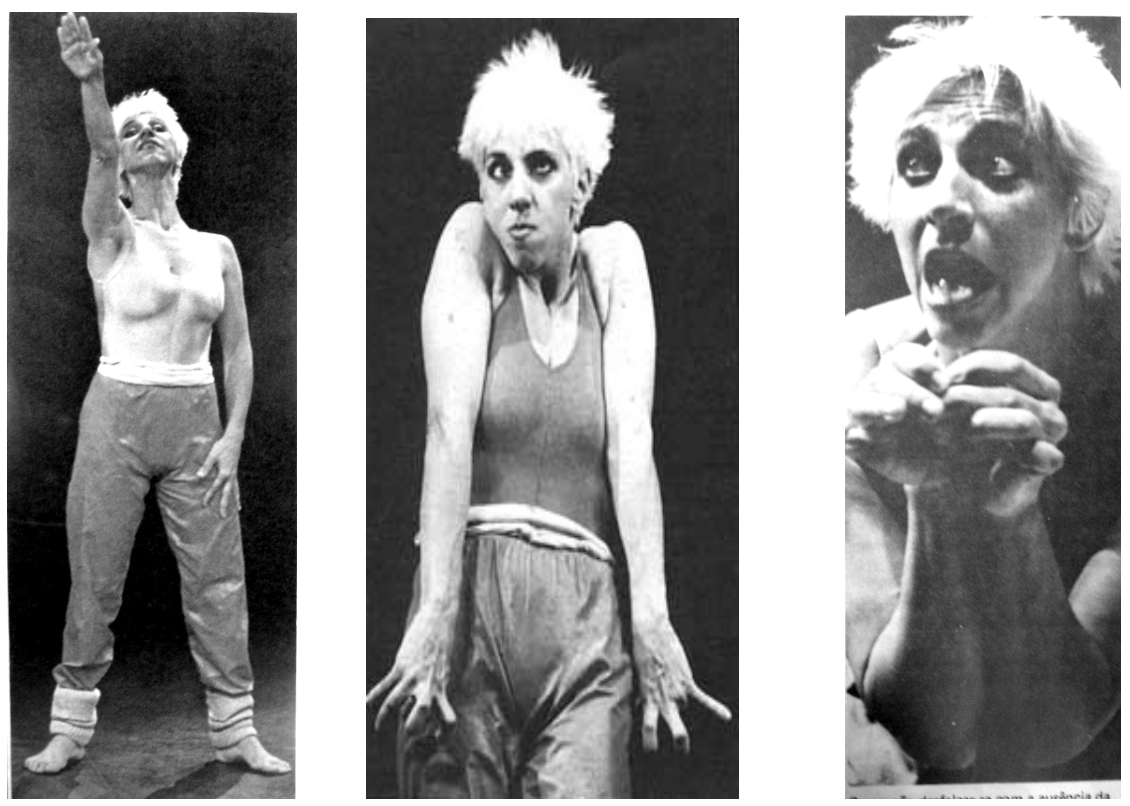

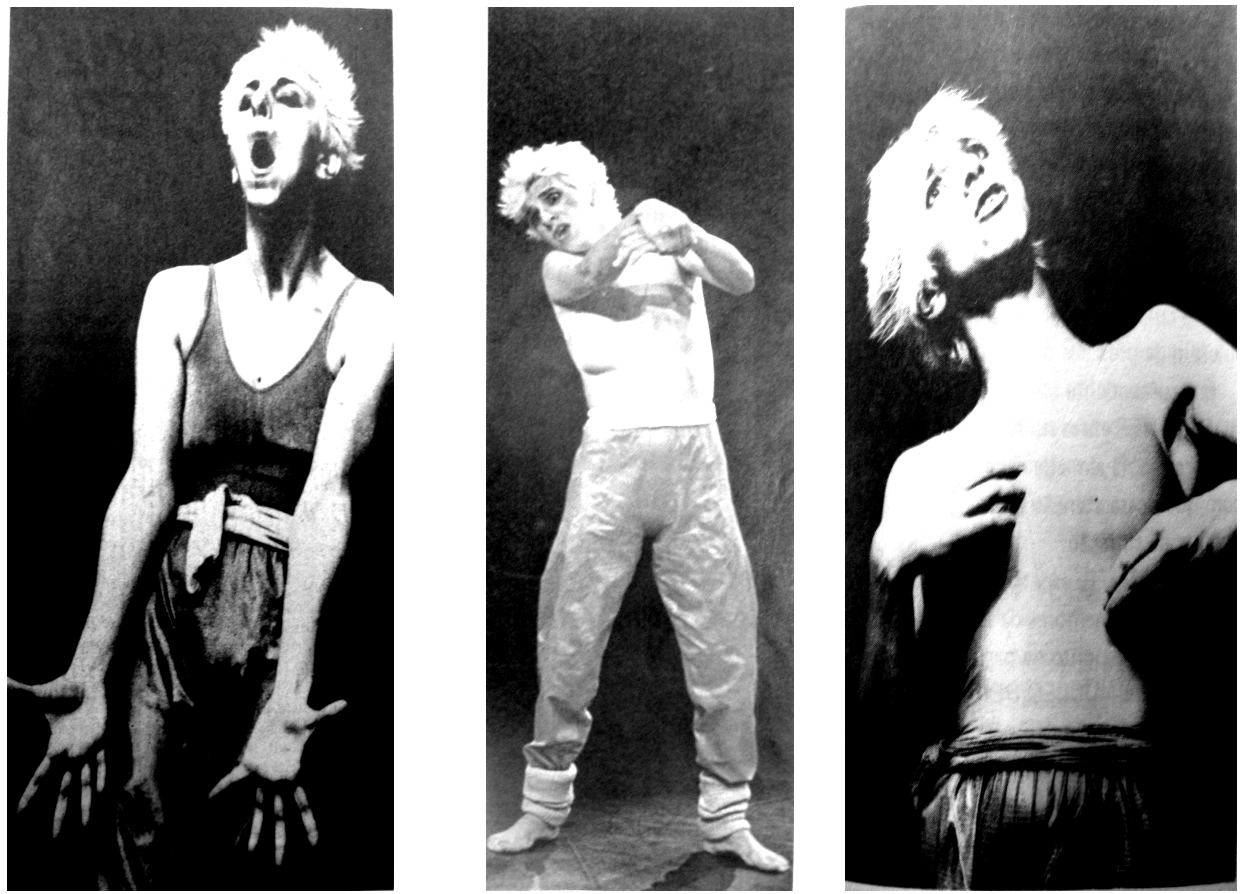

Cenas de Um Orgasmo Adulto Escapa do Zoológico.

Cabe aqui um parêntese sobre o papel da influência de Antônio Abujamra no desenvolvimento do processo de estruturação da linguagem solo de Stoklos. Segundo ela, quando Antonio Abujamra a conheceu, no início da década de 70, ele "também começou com aquelas coisas do meu diretor [Oraci Gemba]: "Olha que voz! Olha que expressões faciais! Mais, mais!"” (STOKLOS, entrevista). E quando ela voltou de Londres, foi ele quem acolheu o seu trabalho, abrindo-lhe as portas do TBC para a reestréia de Denise Stoklos - One Woman Show no Brasil. A parceria iniciada entre os dois a partir de 1982 também se desdobrou no desempenho da função de coreógrafa em algumas peças dirigidas por ele. A convivência, a observação da maneira de organizar a cena, os ensinamentos decorrentes do exercício prático e a grande bagagem teatral de Abujamra resultaram num processo de aprendizado sempre almejado por ela, ou seja, a seleção dos conteúdos e a forma de aplicá-los está totalmente a cargo do aprendiz.

De 1983 a 1986 ela mantém Elis Regina e Um Orgasmo Adulto Escapa do Zoológico sendo apresentados regularmente pelo Brasil e excursionando pela Europa, E.U.A. e América Latina (em 1985, no Rio de Janeiro, ela ganha o Prêmio Mambembe de melhor atriz por sua interpretação em Um Orgasmo Adulto Escapa do Zoológico). Nesse 
período faz apresentações de dois outros trabalhos que tiveram vida curta: Maldição (1983) criado pelos seus alunos, fruto dos workshops ministrados em São Paulo, e Habeas Corpus (1986), com a colaboração de Antonio Abujamra.

Observa-se que à medida que os espetáculos vão sendo apresentados, alguns são retrabalhados e passam a fazer parte do seu repertório, numa espécie de working in progress, um lento processo de ruminação, que culmina sempre na tomada para si da autoria do espetáculo. Elis Regina, por exemplo, que na primeira versão contava com uma assistente de direção e com a participação especial de um ator, na sua terceira versão apresentava Stoklos como a única presença em cena, assinando a direção, o roteiro e a sonoplastia. Em Um Orgasmo Adulto Escapa do Zoológico, na primeira apresentação em língua inglesa, em 1987, o formato era o solo, e trazia seu nome na direção e na adaptação do texto.

Em dezembro de 1986, com uma bolsa concedida pela Fundação Fullbright, ela embarca para Nova York para fazer um estágio de três meses no American Mime Institute, que ficará inconcluso, pois acaba entrando em desacordo com as exigências da instituição, da obrigatoriedade de ter de se manter no que ela considera como os estreitos limites da linguagem da mímica, cuja preocupação é eminentemente com virtuosismo técnico. Numa de suas últimas entrevistas antes de viajar para iniciar o estágio, já se manifestava a sua inquietude com relação ao papel transformador que o teatro deveria ocupar na sociedade:

Hoje o povo vai ao teatro para ter uma vivência bem superficial, alienada no sentido essencial. No máximo o teatro é catártico. Mas não provoca aquela fisgada na estrutura emocional. Não promove rupturas, nem crescimentos... A proposta é quebrar as referências rítmicas. E, com, isso provocar uma emoção de dilatação da vivência [...] A mímica é uma experiência anárquica (OESP, 21/10/1986, p. 6, grifo nosso).

A busca por um teatro que transforme o espectador, engajado com questões relevantes e urgentes, que vá além do simples entretenimento a faz romper definitivamente com o que ela considera como supérfluo e alienante na linguagem cênica. Esse momento é crucial na sua carreira, um verdadeiro divisor de águas, pois será nessa sua estada nos E.U.A. que ela elaborará as bases do seu Teatro Essencial.

A diretora artística do Teatro La Mamma em Nova York, Ellen Stewart, que tomou contato com o seu trabalho ao assisti-la em Um Orgasmo Adulto Foge do Zoológico no 
Festival Internacional de Teatro de Montevidéu, também a tinha convidado para trabalhar como artista residente no seu espaço, na mesma época, até março de 1987.

Desse período de residência no espaço de Stewart surgirá Denise Stoklos in Mary Stuart, oficialmente o solo inaugural do Teatro Essencial. Sua estréia data do dia 19 de fevereiro de 1987 no Teatro La Mamma, mas a sua "gestação", na verdade, começou três anos antes quando Stoklos tomou contato com o texto original, Mary Stuart, da italiana Dacia Maraini, uma adaptação de Mary Stuart de Schiller.

Após esse primeiro contato, o texto de Maraini foi montado por ela, ao lado de Beth Goulart, sob a direção de Antonio Abujamra, e estreou em julho de 1986 no Rio de Janeiro. Nessa primeira montagem Denise e Beth se revezam nas quatro personagens do texto - a rainha da Escócia Mary Stuart e sua criada; a rainha da Inglaterra Elizabeth I e sua criada envolvidas no tema do isolamento e confinamento feminino.

Para a (re)estréia em Nova York, em 87, municiando-se de uma câmera de vídeo e aproveitando a estada de três meses no La Mamma, ela se autodirigiu, adaptou e reescreveu a peça segundo a sua própria visão, reduzindo as quatro personagens para apenas duas: Mary Stuart e Elizabeth I. Interpretando sozinha as duas personagens, o espetáculo levava também sua assinatura na sonoplastia e no figurino.

Com o fim da temporada é lançado o Manifesto do Teatro Essencial que compila de uma forma mais direcionada as suas propostas. $\mathrm{Na}$ fase anterior ao lançamento deste, que vai de 1979, com a estréia do seu primeiro solo Denise Stoklos - One Woman Show, até essa data, os aspectos teóricos encontram-se bastante dispersos e mais ligados ao rigor da mímica de Étienne Decroux e de um processo de desconstrução da mesma, a partir do treinamento com Leonard Pitt, com quem ela começou a experimentar desmanchar o gesto ao invés de finalizá-lo, permitindo que o mesmo desemborcasse em um outro inesperado, desassociando-o da palavra, para que, libertos da correspondência, outras possibilidades expressivas fossem exploradas.

Um outro fator importante, que não chega a ser uma base teórica ou técnica, mas que vai se tornar um dos princípios do Teatro Essencial, é o posicionamento ético e ideológico, decorrente do ambiente convulsivo dos anos 70, que sedimentará o caráter de engajamento da linguagem. O compromisso humanitário estará sempre presente em todas as instâncias, sendo indistinta a sua influência no palco e na vida. 
Os colaboradores, que foram uma presença constante nas produções dos solos dessa fase, vão se tornar menos atuantes, abrindo espaço para que as funções e todo o processo de criação torne-se centralizado. A concentração dos meios de produção, criação e circulação vai permitir que a tendência esboçada do working in progess possa se tornar fator inalienável na criação dos solos.

A importância assumida pelos conteúdos pessoais e autobiográficos, combinados às questões de gênero e de identidade, vai ser tão preponderante, que será impossível conjecturar qualquer espécie de apreciação sobre o Teatro Essencial sem levar em conta esses operadores. As temáticas estarão sempre atendendo a solicitação de manifestação dos mesmos, o que resultará numa permanente (re)apresentação de fixações, mitologias particulares, reminiscências e obsessões.

O próximo capítulo será dedicado à aferição do grau de complexidade alcançada por todos esses elementos, ao serem configurados na forma espetacular. Por ser característico dessa linguagem o seu caráter aberto e processual, localizaremos novos operadores que certamente passarão a fazer parte da estrutura do Teatro Essencial. 
Capítulo 2

O Teatro Essencial 


\subsection{O Solo: algumas consideracões}

O capítulo anterior adotou um viés cronológico para localizar, na trajetória de Denise Stoklos, os aspectos que se tornaram substratos na criação do seu Teatro Essencial. Partindo do pressuposto de que todos os espetáculos da sua carreira, apresentados a partir de 1987 até o presente momento, são considerados por ela como "peças essenciais" (assim denominado o espetáculo construído dentro dos preceitos do Teatro Essencial), qualquer um dos espetáculos tomado como exemplo, a partir daquela data, reunirá em si os aspectos necessários para o estudo e melhor compreensão do que é o Teatro Essencial.

Por esse motivo não há necessidade de apresentar e comentar todos os espetáculos que fazem parte da produção de 1987 até hoje e, sendo assim, serão escolhidos somente aqueles julgados como os mais relevantes para esta pesquisa. $\mathrm{O}$ aparecimento dos mesmos ao longo do restante deste trabalho também não se aterá à cronologia de estréias, e sim como exemplificação de alguma questão que mereça esclarecimentos mais profundos.

Um outro fator de recorte foi o enfoque central desta pesquisa: os caminhos propostos para um sistema de atuação solo. O espetáculo Solo é um gênero teatral pouco difundido no Brasil. A sua presença é mais freqüente em países de língua inglesa, onde é conhecido como One-Man (ou One-Woman) Show ou Solo Show, devido principalmente à sua ligação com a tradição do Music-Hall. Ele também tem um parentesco estreito com um outro gênero cômico inglês, o Stand-Up Comedy (também conhecido como "humor de cara limpa"), que assim como o espetáculo solo também é interpretado por uma única pessoa em relação direta com a platéia, sem o auxílio da quarta parede, diferindo do Solo Show por, em geral, o comediante se encontrar sempre de pé, munido de um microfone, sem o auxílio de personagens e de ambientação cênica. A comédia do tipo Stand-Up no Brasil tem atualmente os seus representantes mais significativos nos trabalhos de artistas como Chico Anísyo, Jô Soares, Ary Toledo, Tom Cavalcante, e nos espetáculos apresentados pelo Clube da Comédia Stand-Up e pelo Terça Insana.

Em geral ao espetáculo Solo é associado um caráter depreciativo quando comparado ao teatro tradicional devido ao seu aspecto improvisado, de estrutura aberta, que lhe confere um aspecto de sarau ou teatro de variedades destinado somente ao riso e ao entretenimento 
ligeiro. A sua estrutura, porém, é bem mais ampla, permitindo a inserção de esquetes cômicas, músicas, monólogos dramáticos, poesias, relatos pessoais e autobiográficos, cenários, objetos, caracterização, aparatos tecnológicos etc., mediados pela presença do show-man, que pode ou não contar com colaboradores na direção, na roteirização, na produção e nos aspectos plásticos.

Pela sua variedade e amplitude, que congrega diferentes estilos de artistas, de Laurie Anderson a Whoopi Goldberg, o espetáculo Solo atualmente também é conhecido como Solo Performance (performance solo), passando a ser configurado dentro do universo da Performance, agregando artistas das artes visuais e da dança. É possível aos artistas de formações e estilos diferentes buscarem um canal expressivo por meio do espetáculo Solo devido a sua característica ancestral: "basicamente, todos os performeres solo são contadores de histórias" (BONNEY, 2000, p. XIII).

Pela figura do contador de histórias outras manifestações artísticas podem encontrar um canal renovado de expressão na contemporaneidade. A retomada dessa arte se "insere na corrente do teatro-narrativa, que dramatiza materiais não-dramáticos e casa perfeitamente a atuação e a narrativa" (PAVIS, 1999, p. 69), restabelecendo as pontes com as tradições orais, nas quais indivíduos assumiam perante a sua tribo ou grupo social o papel de porta voz dos mitos, lendas, fatos do cotidiano da sua comunidade. O Griot africano, o Mimo grego e o Trovador medieval são bons exemplos dessa tradição.

$\mathrm{Na}$ história do teatro brasileiro, o espetáculo Solo encontrou seu campo mais fértil de expansão no teatro musicado, de fins do século XIX até as primeiras décadas do século XX, onde o Teatro de Revista, com a sua estrutura flexível de quadros recheados de músicas, danças, anedotas e alegorias, criticava e comentava os fatos mais relevantes do cotidiano, exprimindo os sentimentos e opiniões de praticamente todas as camadas da população. Os momentos com características do espetáculo Solo podiam ser encontrados nos números de cortina, onde um cantor ou ator sem depender de recursos cenográficos, entretinha a platéia preenchendo o tempo entre as trocas de cena; ou no histrionismo dos atores nos quadros cômicos, lançando mão dos mais variados artifícios satíricos para conseguir a atenção da platéia (vale aqui a recordação de uma cena clássica de uma chanchada onde grande Otelo aparece travestido de Julieta); ou mesmo aparecer em 
qualquer outro ponto da Revista, pela possibilidade que o enredo descontínuo, semelhante a uma colcha de retalhos, propiciava à coexistência de estilos variados.

Foi naquele período também que o ator se tornou o centro do teatro nacional. Grandes intérpretes como Procópio Ferreira e Leopoldo Fróes, de grande poder de comunicação com a platéia, centralizavam nas suas mãos o controle das suas companhias, fazendo com que todas as instâncias da produção teatral girassem em torno da sua personalidade. Tais atores desenvolveram um modo peculiar de atuação, bem brasileiro, procurando no público o seu parceiro de cena, tendo o improviso e a comicidade como requisitos indispensáveis. Muitos eram provenientes do circo, como Oscarito e Grande Otelo, demonstrando uma versatilidade corporal e vocal que os aproximavam de verdadeiros virtuoses.

Com as transformações iniciadas a partir da década de 40, principalmente pelo Teatro Brasileiro de Comédia (TBC), a cena nacional se "modernizou", deslocando o foco para o encenador e para o texto dramático. Era o ocaso dos primeiros-atores e das grandes divas do teatro, que migraram para o rádio e para as chanchadas do cinema; mais tarde, com a modernização, chegou-se aos programas humorísticos da TV, que já dão mostras de desgaste pelo uso abusivo da linguagem.

Os solos de Stoklos resultam da confluência dessa herança brasileira com o amplo universo da performance solo, recebendo o nome de Teatro Essencial. Para a melhor compreensão da evolução dos elementos mapeados na primeira parte desta pesquisa, a cronologia dos mesmos foi dividida em três fases, de acordo com a recorrência da temática em discussão:

- Na década de 1980: fase em que o tema dos exilados e presos políticos está em maior relevância frente a outros conteúdos pessoais. Os solos desse período são: Denise Stoklos in Mary Stuart (1987) e Hamlet em Irati (1988).

- Na década de 1990: a discussão sobre a identidade transita do contexto pessoal, no início da década, para um questionamento em âmbito nacional. São eles: Casa (1990), 500 Anos - Um Fax de Denise Stoklos para Cristóvão Colombo (1992), Amanhã Será Tarde e Depois de Amanhã nem Existe (1993), Des-Medéia (1994), Desobediência Civil (1997) e Vozes Dissonantes (1997). 
- Nesta primeira década dos anos 2000: os espetáculos tornam-se intimistas e existenciais, opondo-se ao movimento da década anterior que apontava os seus vetores para o mundo à sua volta. Temos até o momento: Louise Bourgeois - Eu faço, Eu desfaço, Eu refaço (2000), Calendário da Pedra (2001) e Olhos RecémNascidos (2004).

Para efeito das discussões que se seguem, foram escolhidos quatro desses solos para que fosse possível uma análise mais aprofundada dos mesmos. A seleção procurou contemplar pelo menos um espetáculo representativo de cada segmento descrito acima e que tivessem sido assistidos por mim, pois eu teria tanto informações do processo evolutivo da linguagem, como da sua manifestação prática.

As opções recaíram sobre Denise Stoklos in Mary Stuart, solo inaugural do Teatro Essencial, Casa e Vozes Dissonantes, abertura e encerramento da década de 90, e Calendário da Pedra, o último dos anos 2000 que nos parece reunir as mesmas características espetaculares dos outros três, pois Olhos Recém-Nascidos, no meu modo de ver, com a sua proposta de prescindir dos movimentos corporais e somente se sustentar no discurso oral, se afigura como uma experiência que ainda busca o assentamento de suas bases.

Cabe ressaltar que o total de produções cênicas do Teatro Essencial englobam, em menor número, outras peças que não se encaixam na estrutura solista. A cronologia completa vai em anexo. 


\subsection{Uma Proposta Brasileira ${ }^{7}$}

A estréia do solo Denise Stoklos in Mary Stuart, adaptação do original Mary Stuart de Dacia Maraini, no ano de 1987, marcou as comemorações dos 25 anos de fundação do Teatro La Mama de Nova York. A temporada, de 19 de fevereiro a 01 de março, foi estendida por mais uma semana devido ao sucesso de público e crítica. $\mathrm{Na}$ época, nas entrevistas concedidas aos jornais estadunidenses, Stoklos já expressava os conceitos do Teatro Essencial, cuja idéia surgiu paralela à montagem da peça. A escrita do Manifesto do Teatro Essencial será posterior, em março de 87, ou seja, a formalização só ocorreu depois de serem postas em prática as questões que a afligiam antes mesmo da viagem aos Estados Unidos.

O manifesto é um "balanço do contexto que se faz teoria e prática no decorrer da história confectiva do meu teatro: o essencial" (STOKLOS, 1992, p. 14). Ele expõe as memórias de infância, as opções políticas, os caminhos profissionais, enfim, o pano de fundo da busca de uma expressão artística que sintetizasse uma história de vida. Também fica estabelecido que a partir de então essa expressão artística recebe o nome de Teatro Essencial, e que a criadora e porta-voz do mesmo é a própria Denise Stoklos.

Os manifestos sempre foram um ato performático dos artistas, "que tentaram encontrar outros meios de avaliar a experiência artística no cotidiano" (GOLDBERG, 2006, p. VIII), atraindo para si atenção do público e dos críticos, disseminando e intervindo em espaços não-convencionados para a expressão artística. $\mathrm{O}$ manifesto conferia ao artista uma presença provocadora na sociedade.

A escolha de utilizar a forma do manifesto para levar a público as idéias formais, conceituais e políticas nas quais se baseia a criação do Teatro Essencial, remete-nos a outros realizadores cênicos que fizeram uso deste mesmo recurso para marcar uma nova fase em sua trajetória artística. Um exemplo recente é Tadeusz Kantor ${ }^{8}$ que, em vez de produzir uma obra teórica específica, levava a público as suas reflexões sobre o teatro por

\footnotetext{
7 Título homônimo do manifesto Uma Proposta Brasileira.

8 Tadeusz Kantor (1915 - 1990), pintor, cenógrafo, encenador e autor polonês, fundador do grupo teatral Cricot-2 e conhecido sobretudo pelo seu "Teatro da Morte".
} 
meio de um manifesto, que sempre acompanhava o lançamento de um novo experimento cênico. O processo de Kantor, no qual não há a fixação de um conjunto objetivo de técnicas norteadoras do fazer, muito se assemelha ao desenvolvimento Teatro Essencial, no qual também não houve sistematização definitiva de seus princípios, dando-se preferência ao exercício da prática como gerador de novas indagações.

Talvez, o período histórico no qual o recurso do manifesto tenha sido mais empregado seja nas primeiras décadas do século XX, no Modernismo, pelos movimentos artísticos de vanguarda. Herdeiro de todas as descobertas que a ciência vinha empreendendo desde o Renascimento, e que atingiu o seu ápice na profunda ruptura entre espírito e matéria no século XIX, o Modernismo fez da experimentação científica a sua bandeira na busca por novas formas de arte. A renovação da arte viria por meio do domínio da forma, da exploração dos materiais empregados: na pintura, por exemplo, essa exploração se dava na forma como as áreas de cor eram arranjadas sobre a superfície do quadro; a dança, por sua vez, se volta para a respiração, para a contração muscular. E, segundo Roselee Goldberg, nessa prospecção pela forma expressiva absoluta "a performance esteve durante todo o século XX no primeiro plano de tal atividade [...] esses movimentos $[\ldots]$ tentavam solucionar questões difíceis por meio da performance $[\ldots]$ foi na performance que eles testaram suas idéias, só mais tarde expressando-as em forma de objetos" (2006, p. VII).

Ao longo da sua trajetória, Stoklos sempre expressou de alguma forma, em entrevistas e por meio das temáticas dos espetáculos em que estava envolvida, uma preocupação com causas sociais e um engajamento político. No manifesto esse posicionamento se torna uma das partes centrais do programa estético, configurando-se numa plataforma para todas as instâncias da produção de um espetáculo:

\footnotetext{
[...] em meu exercício de atriz, de diretora, de autora, e de coreógrafa, está sempre implícito o meu questionamento ao poder, às injustiças sociais, aos comportamentos padronizados, à estética e à ética rançosas do sistema patriarcal capitalista” (STOKLOS, 1992, p. 6).
}

No manifesto também é proposto para o trabalho de atuação uma exacerbação da "força da presença viva do ator" (STOKLOS, 1992, p. 5) em detrimento do que é considerado por ela como decorativo e descartável: a caracterização, o figurino, o cenário, 
sonorização, os efeitos. O espaço cênico seria neutralizado para que se destaque a figura do ator, a sua presença em cena, que aqui está associada ao uso das idiossincrasias como forma de presentificação de si e gravitação da atenção do espectador. Um paralelo possível aqui são também as colocações de Jacques Copeau ${ }^{9}$, no início do século XX, na criação da Ècole $d u$ Vieux Colombier, que desejava resgatar para o intérprete a sua posição central na arte teatral e para isso "considerava, como primeiro requisito, manter o palco livre de qualquer coisa que prejudicasse a presença física do ator" (LOUIS, 2005, p. 18). Em síntese, a proposta do Teatro Essencial seria:

\footnotetext{
usar [...] o know-how de sobrevivência do brasileiro que é feito às suas próprias custas, apenas com a resistência física e mental, intelectual. Juntar o som e a imagem do ator, seu corpo e sua voz em uma combinação sofisticada, com a mesma valorização qualitativa e quantitativa (STOKLOS, 1992, p. 50).
}

As proposições teóricas iniciais foram sendo melhor buriladas, definidas, condensadas e descritas por meio de outros manifestos, notas, reflexões, textos dramatúrgicos e, é claro, pelos próprios espetáculos. As referências à performance vão aparecer em dois outros manifestos: Uma Proposta Brasileira (1992) e O Performer Essencial Fará Sempre Teatro Político. Instrumentos. Finalidade. De que Cura se Trata? (2001).

Ao ser empregado o termo performance no manifesto Uma Proposta Brasileira, é nítido que a referência não é ao gênero Performance, mas à atuação performática: "Na elaboração do meu primeiro trabalho solo, o título continha a proposta: meu nome e a ação: "Denise Stoklos - one woman show". Sem dúvida iniciou-se então aí minha prática mais agudamente metodológica de performance" (STOKLOS, 1992, p. 30).

\section{No manifesto O Performer Essencial Fará Sempre Teatro Político.}

Instrumentos. Finalidade. De que Cura se Trata? aparece pela primeira vez o emprego do termo "performer essencial", que é a denominação dada a todo aquele que atua dentro dos preceitos do Teatro Essencial. Inquirida do porquê da criação de tal nomenclatura específica, pois as duas designações, ator e "performer essencial”, são encontradas indiscriminadamente nos escritos, ela explica:

9 Jacques Copeau (1789-1949) liderou, em Paris, um movimento de valorização da participação do ator no processo de criação artística que resultou na Mímica Moderna de Etienne Decroux. 
$[P]$ erformer eu gosto no sentido que não é, assim, [...] quando a gente fala ator, a gente pensa que o ator vai lá fazer o texto do Arthur Miller, dirigido por Peter Brook [...] Performer não tem o diretor nem o autor. Ele vai lá e cria [...] com o corpo dele [...] Que nem a Marina Abramovich [...] E esse é o caso do Teatro Essencial, porque o ator não vai reproduzir o que qualquer outro ator [...] vai fazer [...] Ele vai criar de acordo com a estatura dele, com o tamanho do nariz, das mãos [...] Ele vai fazer sempre de acordo com a idiossincrasia dele. Então é único! [...] Daí performer é um pouco mais próximo do que ator [...] parece que dá mais espaço para esse nosso ator do Teatro Essencial, quando ele cria o que ele vai dizer (STOKLOS, entrevista).

A sua visão identifica o campo de atuação do ator restrito a existência de uma literatura dramática, desconsiderando o fato de que na modernidade o ator se separou da estreita relação de dependência para com o texto, ganhando autonomia, e que a dramaturgia passou a ser encarada como uma das matrizes, e não a principal, responsáveis pelo acontecimento teatral.

O fundamento do teatro moderno ocidental, a personagem representativa das aspirações de individuação do homem, é resultado de uma longa evolução, na qual o texto dramático cumpriu o importante papel de estruturar o arcabouço que permitiu a essa personagem alcançar o status de "Ser Individual". O drama psicológico de cunho Realista/Naturalista do século XIX foi o ponto alto dessa evolução, o que lhe deu o prestígio de tradição teatral no ocidente. $O$ ator então teve de se submeter a essa "textocracia", incorporando cada vez mais a personagem, até que não existisse mais distinção entre um e outro, na verdade o que passou a ter relevância era somente a personagem.

Vários pesquisadores ao longo do século $\mathrm{XX}$ já desestabilizaram a concepção "textocêntrica", reconfigurando o olhar sobre a cena e os seus elementos, desdobrando em múltiplas possibilidades as formas de atuação. O Teatro Físico e o seu ator-criador, Pina Bausch e os seus bailarinos-intérpretes, Grotowski e o seu ator-santo, Brecht e o seu ator épico, são apenas alguns dos inúmeros exemplos de que o ponto de partida para se discutir a renovação da cena não pode se restringir a apenas uma oposição à tradição.

Em seu manifesto O Performer Essencial Fará Sempre Teatro Político. Instrumentos. Finalidade. De que Cura se Trata?, ao comparar o ator, que ela chama de ator de ficção, ao "performer essencial", ela afirma que este não lida com personagens e sim com personas, que "há "in-corporamento" das opções do próprio performer, à vista do 
público, na atualidade de sua performance" (STOKLOS, 2001, p. 5). A diferenciação feita entre os dois, performer como aquele que "realiza uma encenação de seu próprio eu [e] o ator [como aquele que] faz o papel de outro" (PAVIS, 1999, p.285), não abarca o fato de que ambos estão "representando" algo, pois por mais que o performer não esteja representando uma personagem, a (re)apresentação de si mesmo sofre os efeitos das características espácio-temporais cênicas. As alterações de ritmo, de energia, de postura etc., já configuram uma intencionalidade significativa que resulta na criação de algo que se deseja exibir.

As teorias de Hans-Thyes Lehmann sobre o teatro pós-dramático podem nos ajudar a aclarar algumas dessas questões:

[...] o teatro se constitui a partir dessa série de elementos que são: pessoas, espaço e tempo [...] O que aconteceu com a modernidade foi que essa forma tradicional de teatro, ou todos esses elementos que estavam relacionados, explodiu [...] ganhou uma autonomia [...] Poder-se-ia falar de outros elementos que sempre constituíram o teatro: o espaço, a linguagem, os corpos [...] uma série de procedimentos e uma série de formas teatrais que a gente costumava ver como coisas muito experimentais, são compostas por elementos tradicionais, coisas que já existiam no teatro. Ou seja, o teatro pós-dramático não é a destruição do teatro, mas uma nova etapa que, com esse distanciamento, pode ser percebido como uma etapa dentro da história do teatro (LEHMANN, 2001, p.11).

$\mathrm{O}$ ator, o humano presente no espaço e no tempo, vivencia e articula no seu corpo o jogo que é capaz tanto de separar o tempo-espaço da cena do tempo-espaço da platéia, remetendo a um contexto ficcional, quanto afirmar a concretude de ambos, presentificando as experiências fundantes do fenômeno teatral. O Teatro Essencial faz parte dessa segunda alternativa, ao buscar reconquistar o lugar de senhor da cena para o "performer essencial" "Lá, apenas os instrumentos do ator: seu corpo, voz e intuição" (STOKLOS, 1992, p. 17) -, pois se por um lado ele se estrutura como uma oposição à tradição, numa esfera um pouco mais ampla (ou mais "essencial", como defende Lehmann) ele não se constituiria como apartado de uma seriação histórica.

Vale ainda ressaltar que, da mesma forma que Tadeusz Kantor, Denise Stoklos continua expressando por meio dos seus manifestos a evolução da sua linguagem, e o que pode parecer contraditório, rígido, ou até mesmo ingênuo, faz parte de um vasto processo de experimentações. Como exemplo disso temos a apropriação do termo performer, catorze 
anos depois da escrita do Manifesto do Teatro Essencial, com a intenção situar melhor a proposta de atuação, descrita no manifesto de 1987 ainda de forma rudimentar.

Um outro ponto a ser observado é que o emprego do termo performer no Teatro Essencial responde melhor ao que se projeta para um "ator iratiano", pois no modo de realizar o seu fazer "tudo passa a ser mais individual. É a expressão de um artista que verticaliza todo o seu prcesso, dando sua leitura de mundo, e a partir daí criando seu texto (no sentido sígnico), seu roteiro e sua forma de atuação" (COHEN, 1989, p. 96). Com isso o termo é adequado perfeitamente ao emprego dos conteúdos autobiográficos e do contexto pessoal na construção dos objetos artísticos, possibilitando o exercício da autoria e da originalidade na criação, questões com as quais Stoklos vinha se debatendo desde o começo da sua carreira.

Espalhados pelos seus escritos e sem uma sistematização objetiva, a proposta de uma instrumentalização do "performer essencial" está baseada em três elementos: no corpo, na voz e na intuição, com cada um deles se desdobrando em mais três:

- O aspecto corporal em espaço, gesto e movimento;

- O vocal em palavra, sonoridade e canto;

- O intuitivo (ou intelectivo) em ritmo, emoção e dramaturgia. Este aspecto é responsável por organizar o corpo e a voz, daí a relação feita com a dramaturgia, que aqui é vista como um pensamento, como a articulação do intelectual e do emocional na organização dos elementos, e não como a escrita de texto. É interessante notar a colocação o ritmo, que em geral está associado ao corpo, ligado à capacidade intelectual. A idéia é que o "performer essencial" busque uma articulação rítmica entre corpo e voz que estimule o público a percepções diferenciadas.

E de que consta o treinamento técnico para o atuante no Teatro Essencial? Nos escritos isso não é estabelecido de forma clara, contudo numa entrevista concedida por Stoklos, ela afirma que "são treinamentos físicos diversos, principalmente relacionados com impulsos, diferentes associações de tempo em uma classe de movimento e sua fragmentação" (apud ROMERO, 1987, p. 20, grifo nosso, tradução nossa). Na mesma entrevista ela também esclarece melhor o uso do ritmo: 
Por exemplo, se quebro um copo, se o pego lentamente, minha atitude, meu ritmo já revelam minhas idéias; se eu levanto o braço com ímpeto para frente tenho uma atitude agressiva, mas se o faço lentamente, minha atitude é carinhosa, amigável [...] Isto tem um significado que não precisa de códigos. É uma tradução da palavra; mas os movimentos estão isentos de códigos (idem, p. 21,).

$\mathrm{O}$ aspecto intuitivo, que se desdobra em ritmo, emoção e dramaturgia (ou pensamento), tem na expressão rítmica o ponto de contato entre sentimento e raciocínio. Essa concepção auferida ao emprego dessa na organização os aspectos subjetivos e objetivos do trabalho do ator, evoca as teorias da Rítmica de Èmile Jacques-Dalcroze ${ }^{10}$, para quem "a consciência do ritmo é também a faculdade de captar as relações entre os movimentos físicos e os intelectuais, e de sentir as modificações que imprimem nesses movimentos os impulsos da emoção e do pensamento" (apud BONFITTO, 2002, p. 12).

As pesquisas de Dalcroze investigaram as relações entre o sentido da música e a expressão do movimento, entre a voz e o gesto, entre o movimento interior e o exterior, resultando na idéia de que é por meio do senso rítmico muscular que se materializam no corpo tanto o tempo quanto as variações espaciais. $\mathrm{O}$ seu objetivo era que com isso o corpo fosse reeducado nas suas inabilidades, reencontrando uma harmonia perdida. E aqui reside a diferença entre as propostas do mestre suíço às de Stoklos, pois em vez de procurar alcançar uma harmonia, um equilíbrio na gestualidade, eliminando os movimentos involuntários, inconscientes, ela se utiliza desses para introduzir uma espécie de acaso que desvia o trajeto esperado do gesto para uma outra resolução, surpreendendo e atraindo a atenção do espectador.

A exemplificação de Stoklos para o uso do ritmo no Teatro Essencial também encontra eco nas palavras de um outro grande mestre do movimento, Rudolf Laban ${ }^{11}$, que teve acesso às teorias de Dalcroze por meio de uma de suas discípulas, Mary Wigman:

10 Pianista e professor de música do Conservatório de Genebra, inicia uma pesquisa a partir da última década do século XIX que o levará a criar a Ginástica Rítmica, ou simplesmente Rítmica. Suas teorias influenciaram vários outros criadores, como Jacques Copeau, que incluiu a Rítmica na Ècole du Vieux Colombier, e Adolphe Appia, que colaborou nas investigações de Dalcroze de 19061926.

${ }_{11}$ O Sistema Laban, denominado até a década de 80 como Sistema Effort-Shape, conhecido internacionalmente como Laban Movement Analysis (LMA), foi desenvolvido em grande parte por Rudolf Laban entre 1936 e 1951, tendo sido acrescido das contribuições de seus discípulos posteriormente. 
A artista interpretando o papel de Eva pode colher a maçã de várias maneiras, usando movimentos de variada expressividade. Pode fazê-lo ávida e rapidamente ou lânguida e sensualmente. Pode também colhê-la com uma expressão destacada no braço estendido e na mão crispada, em seu rosto e em seu corpo. Muitas outras são as formas de ação, cada uma delas podendo ser caracterizada por um tipo diferente de movimento (LABAN, 1978, p. 19).

O impulso pode também ser entendido como a energia física manifestada que precisa ganhar uma forma expressiva adequada. A relação entre o impulso interno e a forma, ou aparência externa do mesmo, define os modos como aquele se configura em movimento visível e comunicativo. Nas declarações de Stoklos, o ritmo cumpre a função de administrar essa energia para dar a expressividade desejada ao movimento, resultando nas diferentes qualidades das suas atitudes. Retornando ainda a mesma entrevista, um outro fator soma-se aos seus procedimentos:

Toda a manifestação corporal do homem está relacionada com a gravidade [...] a gravidade te deixa passivo, te faz cair, tudo o que se faz contra é atitude, é comportamento. Se você se levanta ereto, [...] tem uma atitude tal, se põe-se cabisbaixo, tem outra completamente diferente e não precisa de códigos, não necessita da palavra, não tem que dizer: “Ah, estou triste!”, ao contrário, é uma relação corporal, não consigo levantar-me, é lógico que está triste [...] Para realizar a ação: lutar, tem que lutar contra ela [...] (apud ROMERO, 1987, p. 21).

A reação contra a força da gravidade é realizada por meio desse impulso consciente para a realização da ação. No corpo humano a musculatura anti-gravitacional é responsável por manter, entre outras coisas, a nossa postura ereta. É a musculatura que trabalha incessantemente contra a atração gravitacional, que evita, por exemplo, que as pálpebras permaneçam fechadas em estado de vigília. Em qualquer dinâmica de movimento essa musculatura assegura que os desequilíbrios gerados não superem a estabilidade do corpo.

Contudo, o simples pensamento de realizar um movimento já aciona esse sistema, que se organiza previamente em contrações musculares imperceptíveis, preparando o corpo para os desequilíbrios que ocorrerão. Ele responde a qualquer ação corporal, aqui entendida como sendo composta por quatro elementos: "movimento, sensação, pensamento e sentimento" (FELDENKRAIS, 1972, p.27). Como os quatro elementos componentes da ação estão atrelados entre si, qualquer estímulo, até mesmo uma mudança no humor, influi, isto é, as sensações e sentimentos dão um tônus diferente à musculatura, carregando a ação de intencionalidade, colorido e expressão. O movimento é apenas um dos componentes da 
ação, a sua parte mais visível. As propostas de Stoklos apontam para que tanto a expressividade vocal e corporal estejam atreladas à ação da força gravitacional:

\begin{abstract}
O ator não é ativo. O espaço e o silêncio são ativos, ele é passivo entrando em ação [...] A imposição é do escuro, da força gravitacional, do silêncio. Quando se empurra o chão, se está exercendo uma ação, optativa, diferente do convite: o convite é para ceder ao chamamento da gravidade [...] Sua tensão com o próprio eixo da terra é o fundamento de sua expressão corporal e oral, uma vez que sua oralidade estará se realizando também quanto ao esforço muscular de seu diafragma (STOKLOS, 2001, p.08).
\end{abstract}

Como dito anteriormente, palavra, canto e sonoridade fazem parte da expressão vocal do "performer essencial". São as vibrações da energia vocal, que são fruto dos impulsos, do embate com a gravidade, que vão preencher o ambiente. A palavra é libertada da necessidade de significado, de sua tradução como signo textual, ao ser tratada como material sonoro, o que também a desobriga da manutenção de sua estrutura semântica. Ao se injetar mobilidade e dinamismo na estrutura sonora, a palavra expande suas possibilidades, livre dos estreitos ditames da língua, e é lançada no espaço, completamente permeável às associações e sensações.

Conhecimento dessas modulações e domínio técnico: é o que requer um trabalho artístico que queira lidar com as resistências musculares do sistema anti-gravitacional ao desequilíbrio. Vários criadores no campo das artes cênicas, tais como Doris Humphrey, Antunes Filho, Kazu Ono, Steve Paxton, Luis Otávio Burnier etc., desenvolveram treinamentos técnicos e linguagens, apoiados nas relações do corpo com a gravidade, que se tornaram marca registrada de seus estilos.

A proposta do Teatro Essencial é a instauração de uma nova linguagem, cuja especificidade está centrada na materialidade. As idéias aqui explanadas já são a compilação artística de todos os elementos levantados anteriormente na trajetória de Stoklos. Um pouco de cada experiência de vida, dos conhecimentos adquiridos, dos mestres e parceiros está diluído na formalização desses princípios.

Nos interessa agora o desdobramento espetacular dessas teorias. Os eixos principais que articulam este fazer, corpo, voz e intuição, tem no trato com a gravidade o seu foco de exploração técnica e performativa. As proposições exigem um novo ator, o "performer essencial", para envergar a bandeira desse teatro, um porta-voz que exibiria no corpo, na 
voz e no pensamento o seu pertencimento a essa esfera de atuação. O rigor do convite exige uma atitude pesquisadora dos limites do emprego do seu aparato psicofísico e da expansão dos mesmos, já que a sobriedade cênica cobra-lhe uma dilatação da sua presença.

$\mathrm{O}$ que nos move neste momento é verificar como esses eixos desenvolvem-se no espaço, como a equalização das forças é empregada na emissão do discurso cênico e quais os seus reflexos na organização da encenação. As investigações que se seguem procurarão dar conta destes questionamentos. 


\subsection{Calendário, Mary Stuart e Casa}

Como já dito anteriormente, Denise Stoklos articula as encenações dos seus solos em torno de três eixos: corpo (espaço, gesto e movimento), voz (palavra, sonoridade e canto) e intuição (ritmo, emoção e dramaturgia), sem perder de vista que o Teatro Essencial baseia-se na exploração máxima do corpo e da voz do "performer essencial", objetivando a potencialização da sua presença e a minimização do uso de elementos cênicos. Partindo de um trecho de um dos seus manifestos, é possível rearranjar de uma forma mais direta e sintética esses elementos da encenação:

\footnotetext{
Para o performer essencial, seu instrumento é o espaço e como ele se desloca ali [...] onde colocar seu corpo fora da força gravitacional [...] na sua cena seu material é como ele realiza a expressão e não a evocação em si dela [...] Quanta energia ele impõe a seu corpo, que partes de seu corpo são requisitadas para a execução daquele movimento: isso será sua mensagem (STOKLOS, 2001, p. 5, grifo nosso).
}

O discurso do "performer essencial", o que ele deseja comunicar, é materializado na forma como ele se movimenta em cena, o sentido da sua enunciação está presente no aspecto assumido pela vibração sonora ao se deslocar pelo ambiente e não no conteúdo semântico das palavras. A gestualidade não é para ser compreendida por meio da sua tradução sígnica, e sim pela sua plasticidade. Espaço e qualidade de movimento podem ser assumidos dessa forma como os eixos norteadores da encenação.

A espacialidade é encarada como um oponente. A sua existência é afirmada a partir da potência das suas características físicas, tais como "escuro, força gravitacional, silêncio" (STOKLOS, 2001, p. 8). O "performer essencial”, em contrapartida, afirma a sua presença quando: "[...] apaga o espaço vazio com seu corpo. Toma lugar apagando o escuro [...] [sua] voz entra no silêncio [...] destrói o escuro [...] luta contra a melancolia da inércia" (STOKLOS, 2001, p. 8, grifo nosso). É dessas oposições que nasce o conflito de forças em cena: de um lado há o "performer essencial", que conta com o seu corpo, sua voz e sua intuição, e do outro o espaço cênico com a sua força de gravitação, sua profundidade, sua altura, sua luminosidade, etc. 
É isso que o espectador vê em cena: um corpo submetido a uma força externa e optando sobre como se mover, a vontade do "performer essencial" em não se deixar manipular pela físicalidade do ambiente. O seu gesto, sua mensagem, é a expressão das suas decisões no trato com a força da gravidade. Para expandir o entendimento dessa proposta, tomemos como exemplo as idéias de Doris Humphrey ${ }^{12}$, que fundamentou toda a sua técnica de dança moderna em duas possibilidades: afastar-se de uma posição estática de equilíbrio e voltar a ela, denominado por ela de fall-recovery.

\footnotetext{
Para ela, o ritmo fundamental é o ritmo motor, que acontece na relação do homem com o espaço, via movimento. Esse movimento humano primordial é aquele que envolve a resistência à força da gravidade; força essa que continuamente o ameaça em seu equilíbrio e segurança. $\mathrm{O}$ esforço humano, na luta contra a gravidade, é o centro de sua dança dramática: o homem coloca-se entre a tensão ocasionada pela possibilidade de queda e o risco do abandono (AZEVEDO, 2002, p.76, grifo nosso).
}

Humphrey entendia que todo o gesto tem a sua raiz na ação da gravidade e que dominar esse princípio significaria chegar a essência dos mesmos. Stoklos expressa também esse desejo na sua busca por uma gestualidade que atravessaria as fronteiras culturais, alcançando uma comunicação universal, já que em qualquer lugar do planeta a atração gravitacional se faz presente sobre o corpo, passível assim de compreensão como uma linguagem pré-sígnica. Ao bailarino cabe então, para Humphrey, partindo de uma idéia, encontrar as atitudes correspondentes e administrar as forças que impulsionam os movimentos.

Tomando a gravidade como postulado central, as demais constantes físicas do espaço passam a ser vistas em função daquela. A trajetória de um movimento é traçada entre duas posições de equilíbrio estático, como estar de pé e caído no chão; o tempo e o ritmo passam a ser medidos pela aceleração de queda, ou de recuperação e pela quantidade de movimentos de um ponto a outro do trajeto. A energia empregada na acentuação, e o ponto da trajetória no qual ela incide, vai denotar a expressividade, isto é, raiva, docilidade,

12 Doris Humphrey (1895-1958) bailarina, professora e coreógrafa americana, ex-aluna da Denishawnschool, uma das primeiras a privilegiar o trabalho espacial do bailarino e as noções de queda e recuperação na dança. 
dúvida, calma, etc. O manejo das linhas, planos e volumes criados assim pelo corpo levarão à constituição de uma coreografia, ou partitura, que será seu "texto" cênico.

Ao se falar de gravidade no Teatro Essencial entende-se também que todas as outras relações espaciais estão representadas. Diferente de algumas outras técnicas, que ao partir desse mesmo princípio para construir o seu fazer, admitem a possibilidade do bailarino ou intérprete também ser manipulado pelas forças externas, o "performer essencial" movimenta-se sempre de forma assertiva, ele é sempre o protagonista, o foco, o centro da atenção, simbolizando assim a afirmação do indivíduo que toma as rédeas do seu próprio destino. Pode-se ver nesta proposição toda a trajetória de Stoklos em buscar constantemente o domínio sobre os meios de criação, produção e apresentação do seus trabalhos artísticos.

Para melhor exemplificar tais propostas cênicas, tomemos o solo Calendário da Pedra, baseado no poema A Birthday Book de Gertrude Stein, que estreou no Rio de Janeiro em 2001 e que trata da relação do homem com o tempo, ora fisicamente, ora transcendentemente, tendo sempre em vista o espírito humano frente a essa questão. A peça inicia-se com a entrada em cena de Denise Stoklos vestindo uma malha e carregando em seus braços um colchonete enrolado. Enquanto isso, uma voz em off explica didaticamente os vários significados, simbologias e mitologias ligados à pedra e ao calendário. Os movimentos dela são lentos e marcados: desenrola o colchonete sobre um "monolito de pedra" no centro do palco e começa a interagir com uma série de objetos imaginários, em mímica, e alguns objetos reais. Esses elementos compõem o cenário onde habita a personagem. Ao final da narração em off, ela descreve uma caminhada em círculo, pára em frente ao "monolito" e dirige-se à platéia:
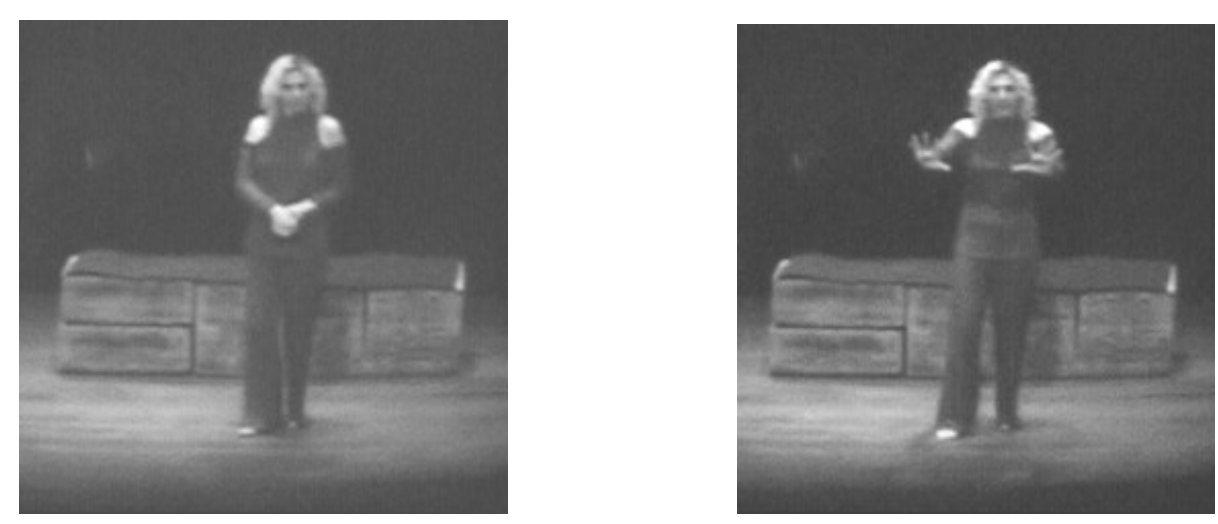

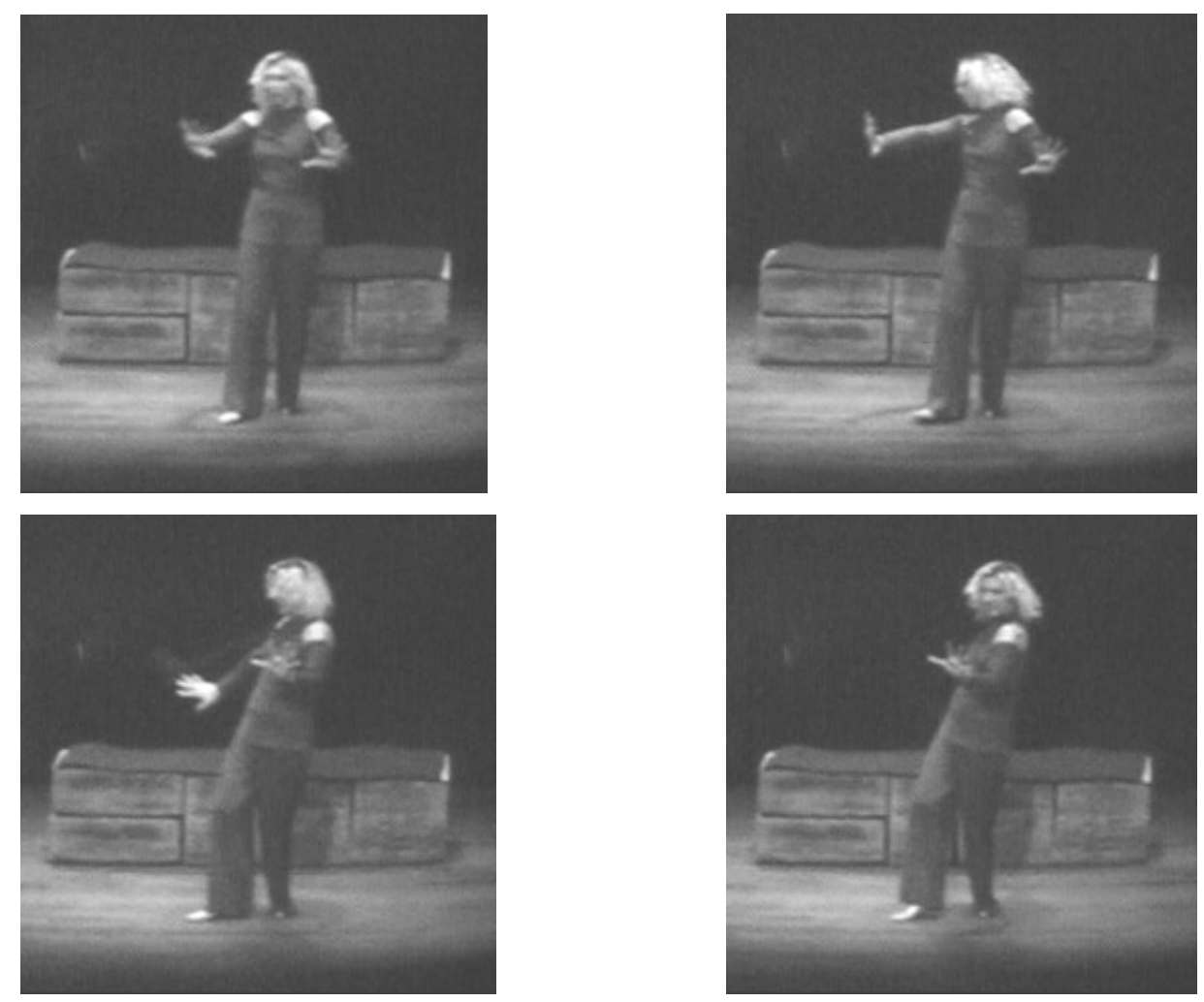

Ela informa ao público que aquele é o ambiente onde a personagem vive, e que é neste mesmo espaço que assistiremos ao rotineiro desenrolar de seus dias. É reforçado o caráter de neutralidade daquele espaço (um lugar qualquer e lugar nenhum) e o caráter de impessoalidade da personagem (não tem uma identidade relevante e muito menos é marcada por algum fado do destino). Todo o prólogo diante da platéia é executado praticamente sem sair do lugar, no máximo alguns passos para frente ou para trás, e mesmo assim a sua presença é magnética:
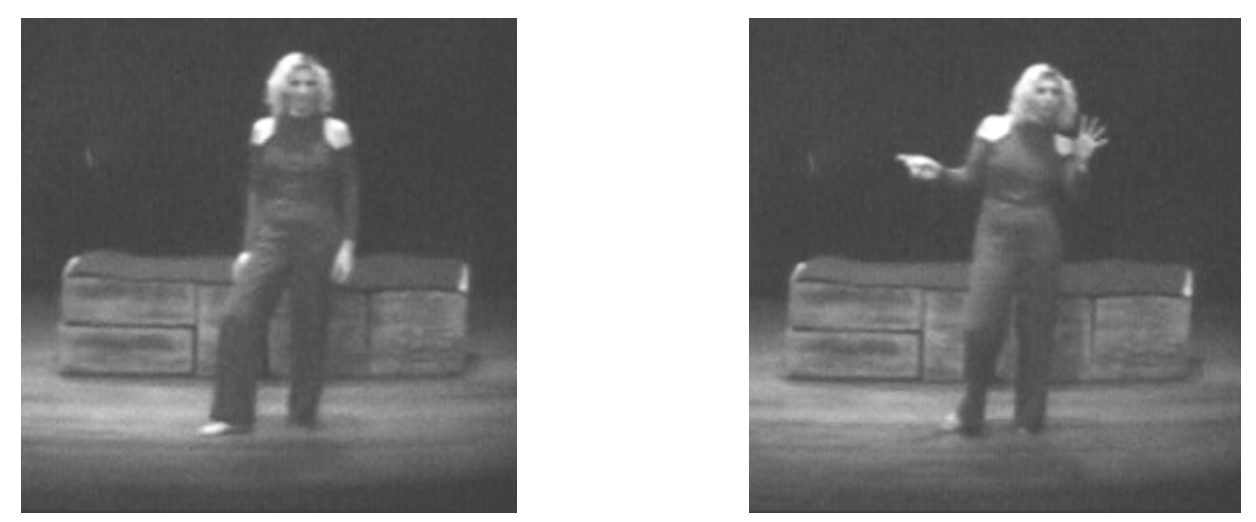

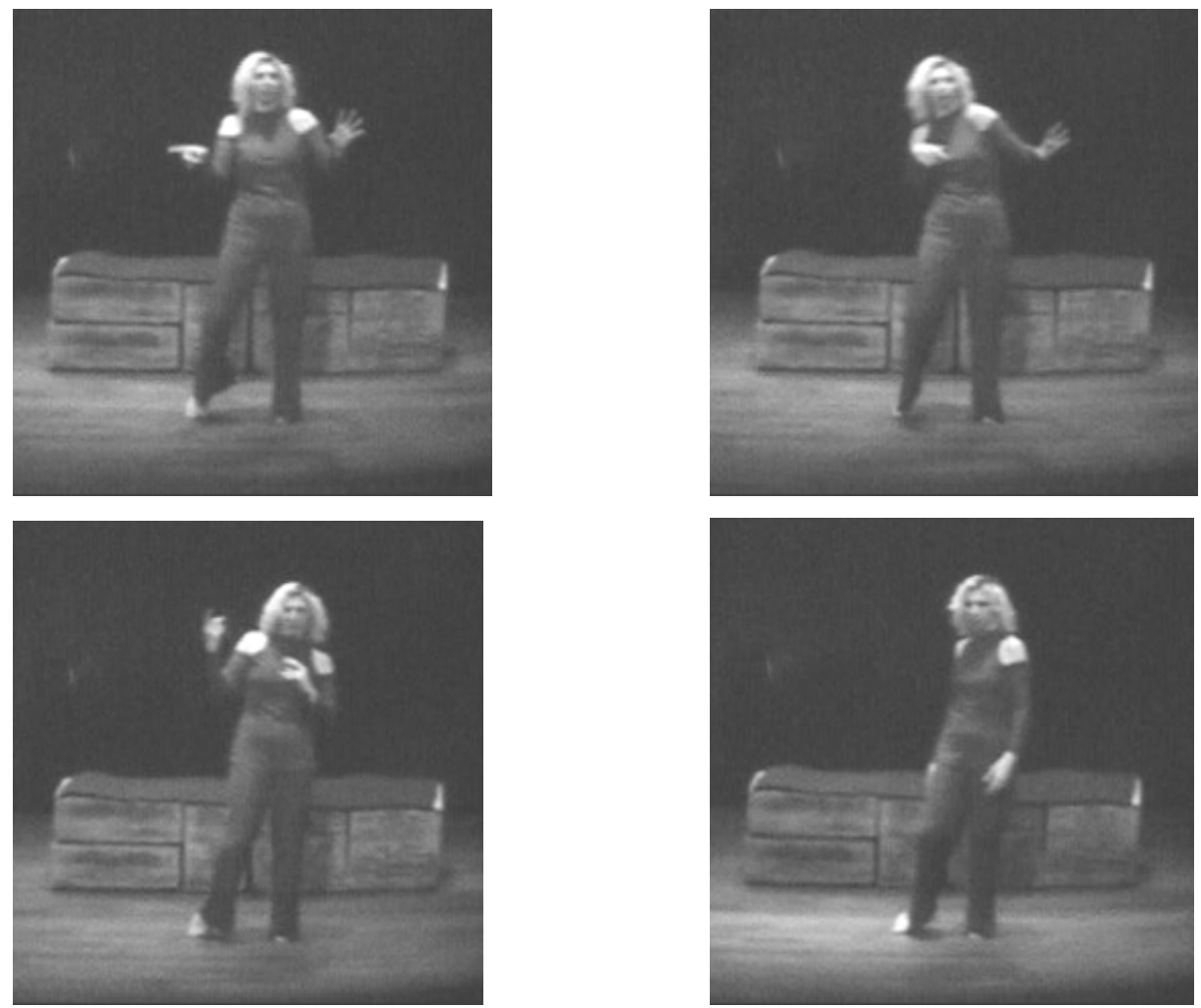

Chama a atenção na sua movimentação a manutenção de um dos joelhos fletido, numa constante troca de apoios. Seu tronco encontra-se sempre deslocado com relação ao centro de gravidade. O corpo está o tempo inteiro deliberadamente em desequilíbrio.

O equilíbrio do corpo é resultado de uma complexa interação entre ossos, músculos e articulações, e o centro de gravidade é o ponto de equilíbrio de todo aquele sistema. Não podemos ver a força da gravidade, mas podemos senti-la atuando em nosso corpo, graças à dinâmica daquele sistema que procura incessantemente reajustar nosso centro de gravidade. Em geral estamos sempre em conflito com esta força invisível, mas se nos mantivermos equilibrados, isto é, numa relação harmoniosa, aparentamos para quem vê elegância e desenvoltura. Porém a desarmonia nos mergulha numa batalha que consome grande parte da nossa energia só para nos manter de pé.

O estudo do equilíbrio torna possível compreender como um equilíbrio em ação gera uma espécie de drama elementar: a oposição de tensões diferentes no corpo do ator é percebida cinestesicamente pelo espectador como um conflito entre forças elementares (BARBA e SAVARESE, 1995, p. 38, grifo do autor). 
De acordo com Eugenio Barba, a "tradição do mímico moderno fundamenta-se no déséquilibre para dilatar a presença cênica" (BARBA, 1994, p. 36), o que nos remete à formação de Stoklos na Desmond Jones School of Mime, escola fundamentada nos ensinamentos Etienne Decroux. A busca do mestre francês sempre foi por tornar o corpo expressivo o máximo possível para que se prescindisse da palavra. Ele trabalhava o desequilíbrio ligado ao impulso e às oposições musculares nas torções, tensões e variações rítmicas para criar um estado de ação permanente do corpo, deixando-o vivaz, energético, expansivo, dilatado e presente. Observando algumas das suas figuras de movimento, podemos notar as semelhanças, que nos levam a concluir que uma das maneiras encontradas para materializar o conflito entre o "performer essencial" e o espaço cênico é o controle do equilíbrio precário a que o seu corpo é submetido:
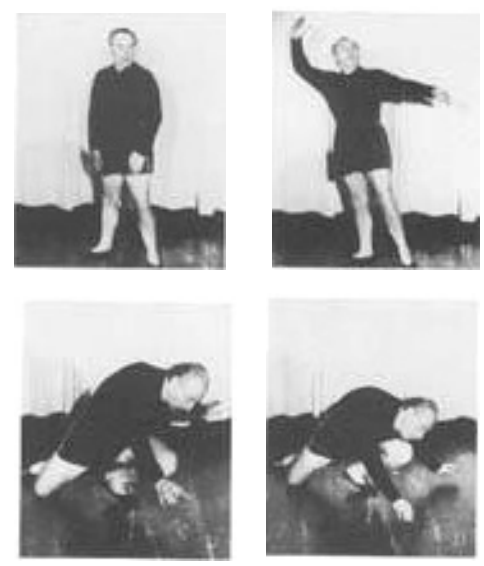

Apanhando uma flor na mímica.
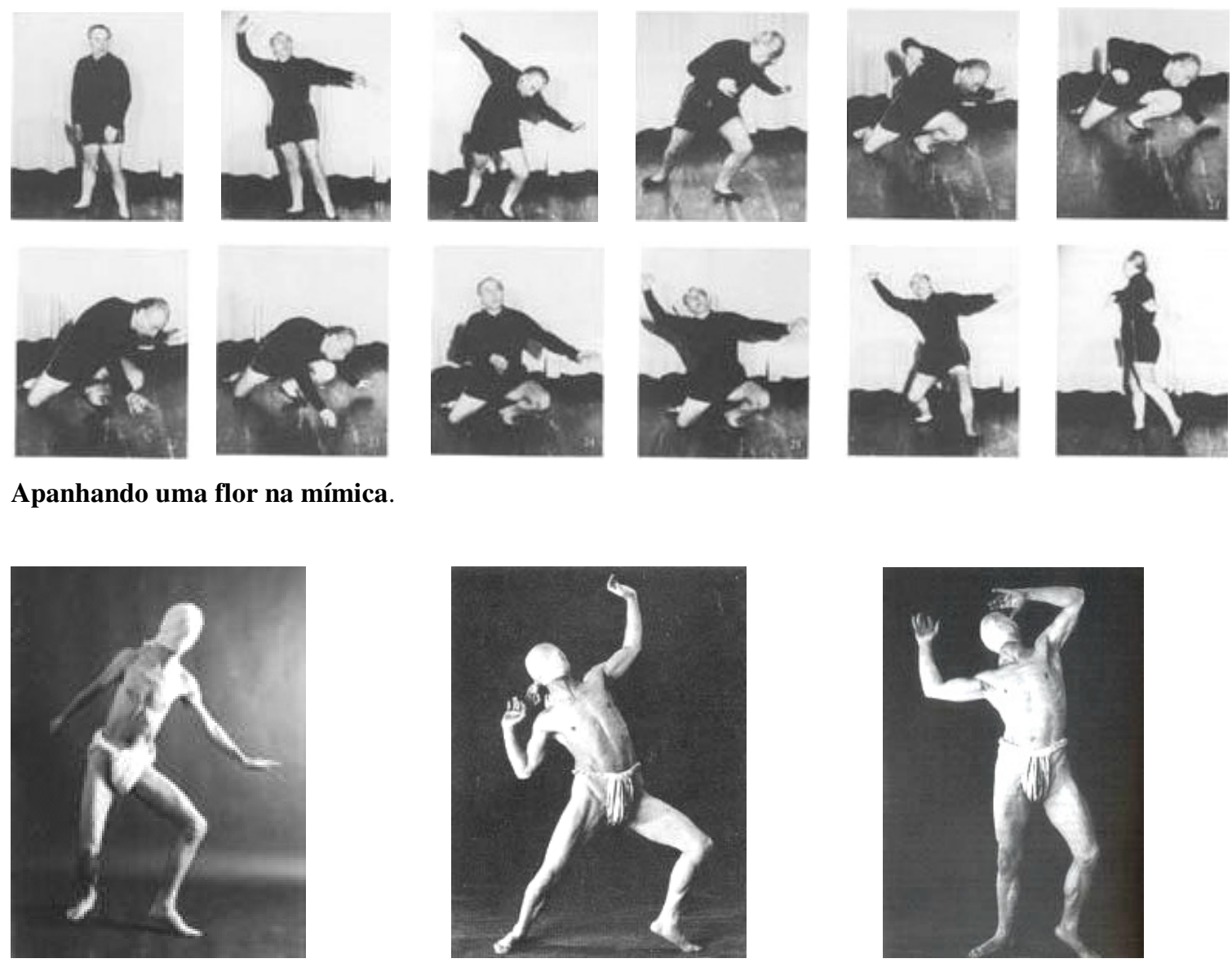

Esportes. 

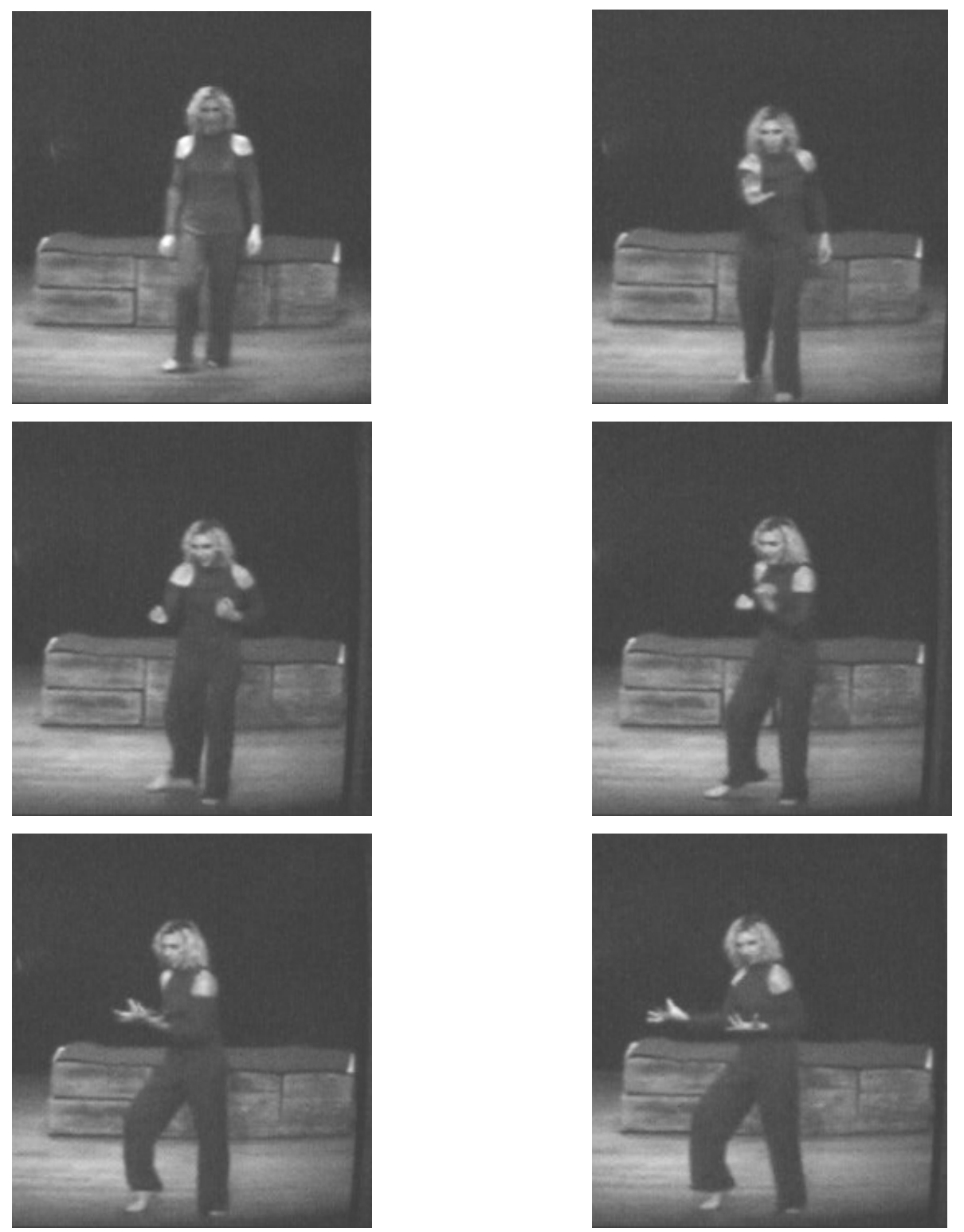

[...] como poderia vir a ser o uso da palavra em meu futuro Teatro Essencial. Desloquei a possibilidade do movimento para o texto, transformando em disciplina o grafismo gestual que recorta, peculiar às técnicas de isolamento e espasmo [...] Usei ainda mais radicalizada a palavra em sua dimensão sonora de intensidade e extensão, ritmo e timbre em relação a um todo cinético - sistema que aparecerá em exercício crescente no desenvolver cronológico das obras que vêm compondo o meu Teatro Essencial (STOKLOS, 1993, p. 30, grifo nosso).

Esse é o ponto em que a aplicação dos princípios da linguagem da mímica difere dos objetivos originais de Decroux. A voz é um dos eixos estruturais da "cena essencial" e está intimamente ligada ao outros dois eixos do sistema. Por isso, "as técnicas de 
isolamento e espasmo" não podem se concentrar apenas na dinâmica corporal. A emissão vocal e o movimento físico são reacionados, impulsionados, pela ação do espaço, este oponente sempre presente.

Com relação à intuição, o "performer essencial" opta, seleciona, encadeia a sua gestualidade e a sua oralidade, sempre perceptivo à ação gravitacional, tendo em vista sempre a rítmica da cena. A dramaturgia está baseada no desequilíbrio, ou melhor, numa inconstância percebida nas quebras de fluxo, andamento e sentido lógico, resultando numa instabilidade desafiadora, numa partitura cuja "gramática corporal não pode ser previsível, pois os olhos esquivam-se de ler, dormem em apenas pensamentos próprios" (STOKLOS, 2001, p. 7).

O tipo de encenação aqui tratada não pressupõe a separação em quarta parede entre palco e espectador, logo as questões em discussão também se referem ao espaço ocupado por este. A "platéia é sempre feita de um público [...] com dificuldade de concentração, de audição e de visão" (STOKLOS, 2001, p. 6), pois os seus corpos estão submetidos da mesma maneira à inércia gravitacional, gerando uma outra urgência na atividade do "performer essencial": a ação cênica não pode prescindir da responsabilidade de comunicação; é necessário resgatar o espectador da sua passividade. Todavia, como não há deslocamento espacial desse, a conquista só é possível por meio das sensações: a informação visual e sonora da cinética da cena provoca uma experiência sinestésica que coloca o público em prontidão.

Para adicionar mais uma camada sobre o papel da fisicalidade no Teatro Essencial, tomemos novamente o solo Calendário da Pedra. O assunto da peça é o tempo e a sua inevitável presença no cotidiano do indivíduo, reduzindo toda a existência a uma sucessão de fatos e acontecimentos que, se pessoalmente parecem singulares e relevantes, no âmbito universal não representam absolutamente nada. Essa idéia é desenvolvida numa análise das situações do cotidiano, apresentadas como numa espécie de diário, onde cada cena representa um dia registrado no mesmo. A peça se inicia no dia $1^{\circ}$ de janeiro e durante uma hora, uma hora e meia, segue uma rigorosa ordenação das cenas (dias), na qual acompanhamos, dia após dia, durante um ano, o cotidiano da personagem, ou melhor, da persona. Porém, em algumas passagens, ela nos informa que pulará alguns dias, já que não há nada interessante a ser relatado. 
Transcrevo um trecho de uma entrevista de Antônia Ratto, assistente de direção daquele espetáculo, que relata um dos processos de escolha de soluções cênicas:

\begin{abstract}
Havia dúvidas sobre a estrutura básica dos movimentos: o que simbolizaria melhor o tema central da peça, que trata de uma pessoa [...] que se confronta com o tempo em todas as suas manifestações? [...] Pensou-se em amarrar os pés da personagem, cujos movimentos se restringiriam desta forma, [...] metáfora de que por mais livres que sejamos há uma força imperativa que de alguma maneira nos imobiliza a todos dentro de sua cadência ininterrupta. Esta mesma idéia, no entanto, acabou sendo traduzida através dos movimentos repetidos de deitar e levantar da personagem na passagem de cada dia, cuja metáfora seria percebida pelo público à medida que o tempo do espetáculo passasse (apud PRADO, 2002, p. 28, grifo nosso).
\end{abstract}

O tema do aprisionamento, já mencionado em Elis Regina e Um Orgasmo Adulto

Escapa do Zoológico, busca a sua materialização por meio de paredes que se fecham sobre o indivíduo, celas, ambientes de contenção, corredores estreitos, salas atravancadas ou, como no caso em tela, na restrição da liberdade dos movimentos ou numa dimensão metafísica, no confinamento aos limites temporais. A metáfora cumpre um papel fundamental nessa operação, pois ela pressupõe transporte, o experienciar uma coisa em termos de outra. O pressuposto aqui é que "todos os temas que encontrem no corpo do ator o empenho necessário para realizar seu esforço serão interessantes pontos de partida e chegada" (STOKLOS, 2001, p. 8), isto é, a temática tem de ser tratada como um obstáculo que exige emprego de energia física para vencê-lo. Tal transposição metafórica também é encontrada na relação estabelecida com a força da gravidade. Temos aqui mais um operador desse sistema a ser empregado pelo "performer essencial" na construção da sua encenação.

O tempo cronológico é presentificado por meio do anúncio que a personagem/persona faz ao espectador do dia e mês de cada cena, que é acompanhado pela repetida marcação cênica de iniciar cada cena (cada dia) levantando-se da cama:
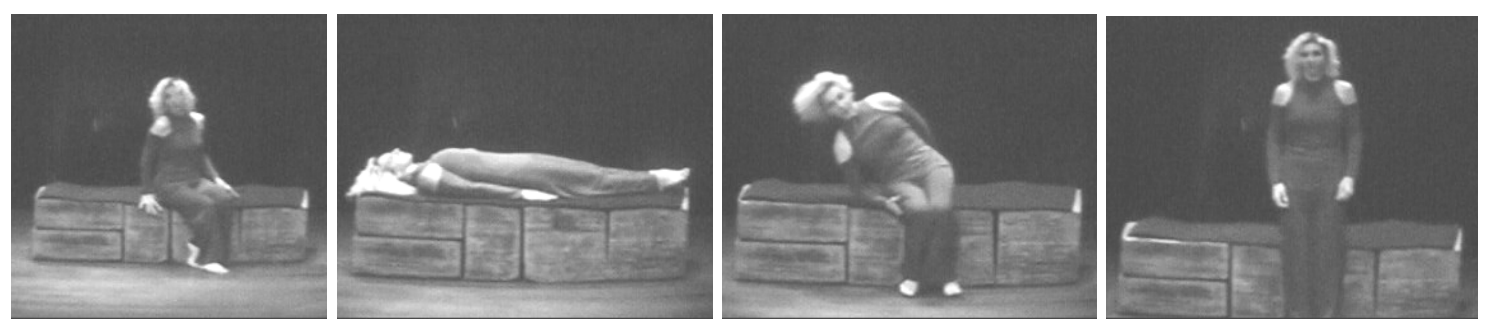
O solo Denise Stoklos in Mary Stuart, apesar de tratar de um outro assunto, se utiliza das mesmas operações, vistas até o momento, na sua estruturação cênica. A peça discute a presença do Estado na vida do indivíduo por meio do tour de force entre duas rainhas, duas poderosas mulheres que não foram donas dos seus destinos justamente por causa do poder: a rainha da Inglaterra, Elizabeth I, e a rainha da Escócia, Mary Stuart, sua prima. O espetáculo, por meio de uma narrativa não linear em que transparece os caminhos tortuosos da política e das relações humanas, mostra os últimos dias de Mary Stuart, que após 20 anos aprisionada é condenada à morte por Elizabeth.

Trajando uma calça de lycra e uma túnica de cor neutra, Stoklos, num esmerado domínio técnico da alternância entre o cômico e o trágico, usa recursos físicos para a caracterização das personagens históricas: estabelece para Elisabeth uma máscara facial grotesca, uma voz autoritária, um andar reto, uma postura rígida, com as mãos apoiadas sobre a saia imaginária, numa atitude quase estatuária. Elizabeth é bastante caricata em relação à caracterização de Mary Stuart, pois esta tem gestos mais humanizados e objetivos, uma fala urgente e de entonação teatral.

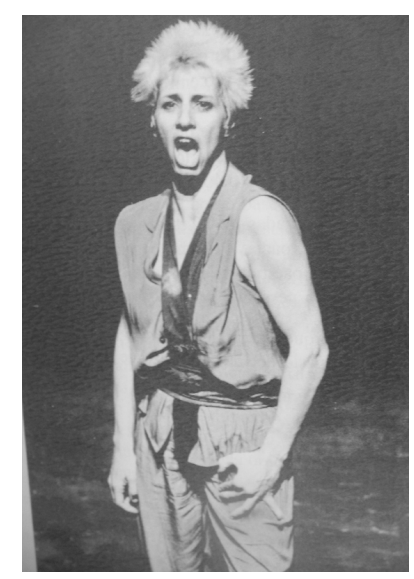

Denise Stoklos / Mary Stuart

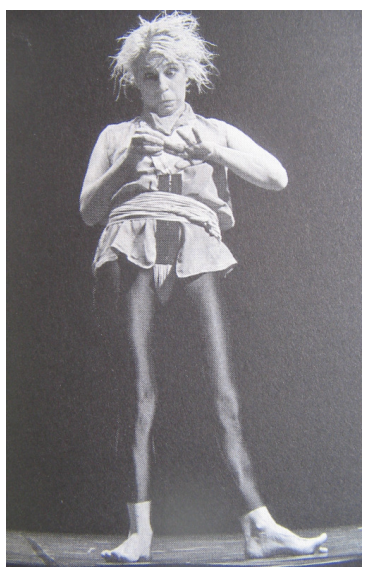

Denise Stoklos / Elizabeth I

A semelhança da caracterização de Mary Stuart com Stoklos torna indistinta a separação entre as duas. Através do corpo da performer estamos conectados à Renascença inglesa e à atualidade, sendo impossível não enxergarmos esta linha do tempo atravessando os episódios de outros presos políticos ao longo da história. De fato, pode-se até dizer que 
esta cronologia se projeta também para o futuro, como um alerta, já que em algum momento todo fato pretérito não representava nada além de uma probabilidade.

Um outro detalhe a ser observado é que ela não representa Elisabeth ou Mary Stuart, e $\operatorname{sim}$ as apresenta: numa atuação de aspectos épicos ela nos informa sobre essas personagens históricas. Desse ponto de vista, há uma terceira "personagem" em cena, que é a persona envergada por ela. Nas suas alternâncias em apresentar Elisabeth e Mary Stuart, em algumas passagens, ela apresenta a si mesma, estabelecendo uma ruptura no espaçotempo e trazendo a ação para a atualidade, observando e criticando o que foi apresentado. O que vemos dessa forma, por intermédio das suas ações, reflexões e comentários, é a sua busca por soluções, sua luta por esclarecimento, sua atitude de resistência, sempre se alternando entre o didático, o arrebatado e o cômico. Aliás, o humor cumpre um papel fundamental nessa dinâmica da alternância, tão presente em todos os seus solos, pois permite que ela se coloque de uma forma divertida e irônica "como uma espécie de espectador "everywoman"” (DAMASCENO, 2003, p. 158, tradução nossa), que sinaliza para o espectador o poder desestabilzador do humor frente às estruturas pré-estabelecidas, que propagam impotência do cidadão comum diante das forças sobre-humanas.

A proposta do Teatro Essencial de minimizar o uso de elementos cênicos ganha maior clareza numa entrevista concedida por Stoklos a um jornal da época, na qual ela declara que "para haver o momento teatral, basta o ator, um objeto, uma iluminação com o espírito da cena. O mínimo possível” (JB, 05/03/1987, p. 7). Esses seriam os dois itens básicos na constituição da cenografia, e pela indicação de que a luz deve estabelecer um diálogo com a cena, pode-se pensar o mesmo para outro.

Em Denise Stoklos in Mary Stuart a essencialidade cenográfica resume-se a uma simples cadeira de madeira sem braços. Os dois espaços ficcionais, a corte de Elizabeth I e a torre onde Mary Stuart está presa, são apresentados alternadamente, porém ocupando fisicamente a mesma área do palco, em torno do objeto. Aquele solitário elemento cênico está presente em ambos os contextos ficcionais: ora é o trono de Elizabeth, ora é o pobre e único assento na cela de Mary Stuart. Ele interliga simbolicamente os dois ambientes, estabelecendo uma relação entre as duas rainhas. Contudo tal ação só se concretiza com a gestualidade do performer, que ludicamente transporta nossa imaginação por meio dos 
saltos no espaço-tempo, acabando por preservar a imobilidade, e por que não dizer imutabilidade, quase que totêmica da cadeira/trono/assento:
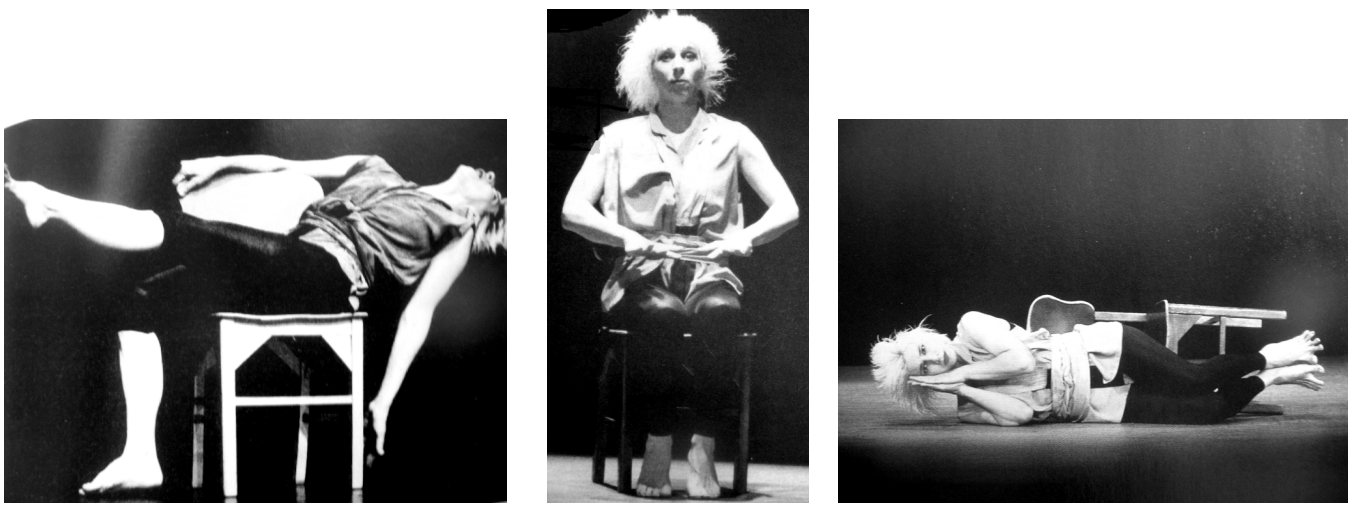

O uso da mímica ajuda a suprir algumas outras necessidades cenográficas, como por exemplo o emprego do recurso da parede invisível para delimitar um cubículo em torno da cadeira, configurando a torre de Mary Stuart. Mas até esse elemento é trabalhado dentro da mesma categoria de significação do anterior, pois enquanto Mary Stuart é enclausurada pelo espaço, Elizabeth movimenta-se livremente por todo ele, todavia sempre em volta de seu trono. De certa forma ambas são prisioneiras, tanto da cumplicidade mantida pelo exercício do poder despótico, quanto do enredamento causado pelas obrigações da coroa. A cadeira além de desempenhar a sua função metafórica refere-se também metonimicamente a todo o cenário pela sua existência única.

Um outro objeto é usado em dois momentos durante a peça, mas a sua existência não tem a função metonímica do anterior. Um telefone promove, comicamente, a ligação entre ambientes e tempos diversos quando, numa primeira cena, Mary Stuart liga de seu claustro para Elizabeth, e em outra Stoklos recebe um telefonema de Mary Stuart:

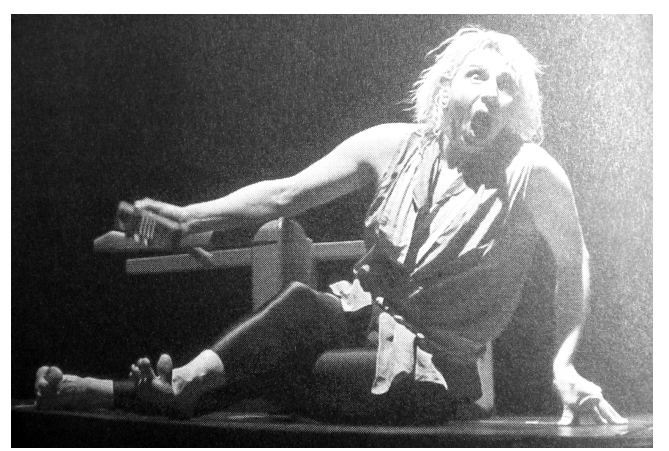


Os artefatos cênicos no Teatro Essencial desempenham sempre um papel metafórico dentro da encenação. Em Calendário da Pedra, por exemplo, eles estão ligados à idéia de comunicação e de cronologia. Além do monolito, disponibilizado tanto como assento quanto leito, os únicos objetos concretos são um relógio de pulso e um jornal, e entre os objetos descritos em mímica, escolhidos para caracterizar o habitat da personagem, há uma TV e um computador. Podemos enxergar, na relação entre a absoluta imobilidade do "monolito de pedra" e as evoluções da performer em torno do mesmo, Cronos no seu apetite bestial a devorar as horas e as existências, ou os grilhões inquebrantáveis que cingem Prometeu à rocha, ou ao eterno retorno à encruzilhada de Vladmir e Estragon.

Contudo as portas que nos libertam da fatalidade do destino ou da absurda existência cotidiana estão ali, personificadas na comunicação que podemos estabelecer com nossos pares, cujo acesso está ao alcance de uma ligação telefônica, como em Denise Stoklos in Mary Stuart, ou em Louise Bourgeois - Eu faço, Eu desfaço, Eu refaço, no qual a própria Bourgeois, por meio de um celular, estabelece um laço com o espectador e com a sua própria história. Na observação de Stoklos: "Só é possível dar passos revolucionários no contato com o outro" (FSP, 05/01/2005, p. E1). Em Vozes Dissonantes são os vultos históricos que nos falam por meio dos livros, em Des-Medéia são os jornais que trazem a atualidade para a cena e em 500 Anos - Um Fax de Denise Stoklos para Cristóvão Colombo o artefato do título é o detonador da ação.

Ainda no que diz respeito à funcionabilidade e à presença dos objetos cênicos, o espetáculo solo Casa (Basement), ao lado de Louise Bourgeois - Eu faço, Eu desfaço, Eu refaço, parece contrariar a máxima do Teatro Essencial de que "basta o ator, um objeto, uma iluminação", pela quantidade de elementos no palco. O espetáculo, uma espécie de working in progress, estreou em 1990 no Teatro La Mamma, em Nova Iorque, como Casa (Lobby), com Stoklos à frente de um elenco de oito atores. Contudo, no espetáculo levado "na mala", intitulado apenas Casa, ela dividia o palco com somente mais uma outra atriz. A versão final, Casa (Basement), estreou no Brasil no mesmo ano, no formato solo, passando a ser chamado a partir de então de Casa. O tema são as relações de um indivíduo com o seu habitat, isto é, o seu lar, e para estabelecer esse contexto são colocados no palco vários elementos reais do ambiente doméstico: cama, geladeira, mesa, cadeira, sanitário, relógio, chaves, pipoqueira... e um aparelho de TV. 
A peça começa com a personagem chegando à sua residência; uma mulher urbana comum, sem identidade definida, trajando um tailleur. No transcorrer da encenação assistimos à inadequação dessa mulher solitária aos únicos seres, além dela mesma, que povoam o seu mundo: seus bens domiciliares. Em geral, na estrutura de um espetáculo solista, a ausência física em cena de um interlocutor humano redireciona o foco de comunicação do atuante para os outros indivíduos fora do seu espaço cênico (o público), ou para os elementos (in)animados dentro do seu contexto de atuação. Os objetos, "ou seja, aqui, tudo o que não é o ator e que representa na cena os acessórios, os cenários, os telões e mesmo os figurinos" (PAVIS, 2003, p. 174) assumem também o papel de sujeitos ao serem manipulados pelo performer solo, ganhando um outro potencial dramático, passado a simularem as relações humanas.

A personagem de Casa tenta acompanhar o relógio que está sempre adiantado; namora a geladeira ao escolher algo para comer e doma um acordeão até conseguir arrancar dele algum som:
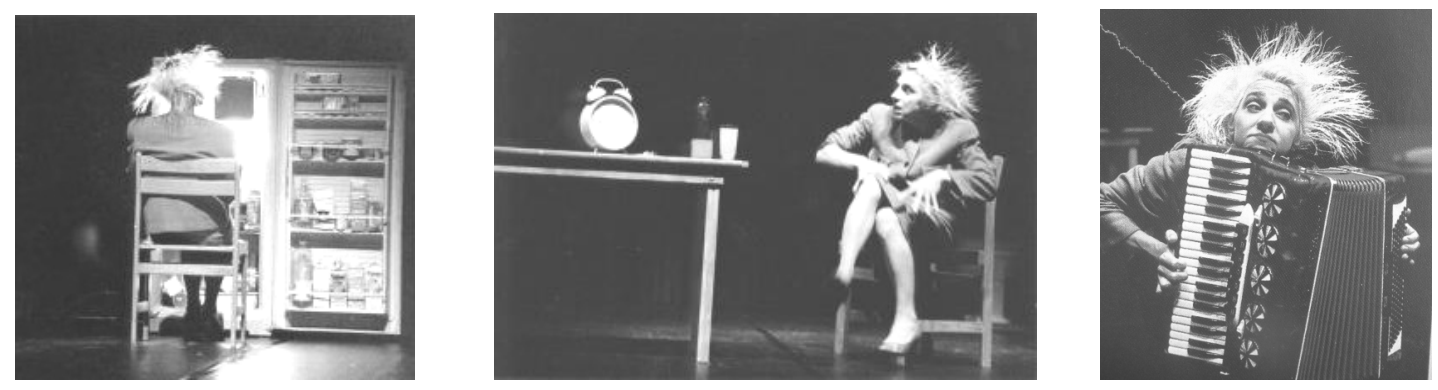

O espaço, e conseqüentemente o contexto, detentor de forças e poderes insuperáveis, adquire flexibilidade a partir da ação daquele único ser humano. O triunfo dela ao vencer a luta com as chaves ao tentar entrar na sua residência põe em relevo a criatividade humana na resolução de situações limites. A inabilidade da mulher em se acertar com o mundo dominado pelos objetos é resolvida na cena final pela sua própria tomada de posição, quando solicita a um contra-regra que esvazie o seu espaço domiciliar, ficando assim livre para realizar outros contextos, outras relações. O objeto nesta estrutura ao invés de permanecer imutável, afirmando somente a sua concretude, ganha mobilidade pela ação do solista. Aqui, como no universo de Tadeuz Kantor, o objeto tem o mesmo 
estatuto que o ator, deixando de ser ilustrativo, passando a ser um adversário, um parceiro de jogo.

Quando o "performer essencial", na sua solidão em cena, busca o "diálogo" com o espaço que o envolve, acaba metaforicamente transpondo a situação, em alguma medida, para as personagens que apresenta. Não importa se em Louise Bourgeois, Vozes Dissonantes, ou Mary Stuart, a enunciação das personagens históricas ou fictícias, anônimas ou individualizadas, está sempre carregada de urgentes questões humanistas, transparecendo a crença de que "a clareza das relações é o único passaporte [...] [e] que o egoísmo está em xeque" (JT, 07/04/1987, p. 18).

Os artefatos ligados à idéia de comunicação revelam uma vez mais a importância dos conteúdos autobiográficos. As vivências adquiridas com a publicação das suas crônicas, ainda na adolescência, no jornal local em Irati, e consolidada posteriormente na formação universitária, está presentificada quando a personagem de Casa, ao jantar em frente à TV, fica condicionada pelo ritmo do programa a que assiste, ou em Des-Medéia, quando se critica a superficialidade das informações contidas nos jornais, ou na denúncia, em Vozes Dissonantes, da parcialidade da história oficial contida nos livros. O acesso à tragédia de Mary Stuart por meio de um telefonema evoca a responsabilidade dos meios de comunicação na sua atuação no seio da comunidade. O caráter missionário dos mesmos é um ícone nos solos de Denise Stoklos.

A regra do Teatro Essencial de resumir os elementos da encenação ao "performer essencial", a um objeto, e à iluminação estabelece o diálogo cênico entre a potência das características físicas do espaço e o atuante, que dispõe do seu corpo, sua voz e sua intuição para a realização do acontecimento cênico. No controle do equilíbrio precário do corpo do ator é que se explicitam as relações entre esses dois parceiros do jogo: o ambiente cênico e o performer.

Os temas recorrentes, tais como o aprisionamento e a comunicação humana, são transpostos metaforicamente para os objetos (e para a iluminação, conseqüentemente) e se tornam os interlocutores do "performer essencial", que ao manipulá-los expressa simbolicamente como o poder da força criativa de um único ser humano pode flexibilizar a rigidez do contexto em que está imerso. A dinâmica da alternância presente na atuação também contribui para dar ao espectador um exemplo de como buscar soluções e 
respostas, quando por intermédio das ações, reflexões e comentários do atuante vários pontos de vista são apresentados.

Nos solos analisados, Calendário da Pedra, Denise Stoklos in Mary Stuart e Casa, vemos como a essencialidade cenográfica é potencializada pelas funções metafóricas e metonímicas que a interligam com os temas, que ganham também nas ações do "performer essencial" um tratamento semelhante. Resta-nos compreender os princípios que organizam essas narrativas no espaço cênico e que direcionam para um mergulho mais profundo na temática apresentada. 


\title{
2.4 "Solo Essencial": Aspectos Dramatúrgicos
}

\author{
O performer essencial pode ter como texto uma lista \\ telefônica. Sua recitação de nomes, endereços e números \\ conterá a musicalidade de suas intenções que uma coreografia \\ pode indicar (STOKLOS, 2001, p. 5, grifo nosso).
}

Dos textos dramatúrgicos publicados de autoria Denise Stoklos, tais como Denise Stoklos in Mary Stuart; 500 Anos - um Fax de Denise Stoklos para Cristóvão Colombo; Casa; Des-Medéia e Calendário da Pedra, nenhum deles foi escrito previamente para ganhar uma encenação posterior. Eles representam, na verdade, o registro em forma de literatura de uma fração do conjunto encenado. No Teatro Essencial pode-se partir de um texto dramatúgico para se chegar à encenação, porém tal texto é visto como um material que contém informações que casam com a temática sobre a qual o "performer essencial" está debruçado. Nada impede que qualquer um encene as peças publicadas, e até mesmo tente reconstituir o seu aspecto original, mas atualizar os elementos contidos num texto dramático não é, com certeza, o vetor para o qual aponta a ação do atuante nesse tipo de teatro.

Na cena contemporânea o texto já não é necessariamente o centro da cena - isto é, não se sustenta mais uma textocracia - para o restante da representação, encontrando-se no mesmo nível de importância que os outros elementos da cena teatral. A idéia é que a encenação seja soberana nos caminhos estéticos que deseja tomar sem ter de obedecer às indicações existentes no texto, que funcionariam como uma espécie de proto-encenação.

A partir dos anos 60, assistimos a uma escalada do grau de importância assumido pela encenação, onde vários encenadores priorizaram a construção de "narrativas" por meio da articulação dos elementos que compõe a cena, que conduziriam a um estado emocional e imaginativo que não necessariamente passava pelo crivo intelectual. A dramaturgia ganhou a possibilidade de se estruturar como uma partitura cênica (um "texto" que não se escreve 
previamente e sim que surge em cena) que organiza o corpo, a imagem, o som, o texto e o espaço numa hierarquia que depende da estética sobre a qual versa o criador.

Antônia Ratto - "Quando eu entrei no processo, a Denise já estava com a primeira versão do texto pronta. Depois houve modificações à medida que os ensaios foram evoluindo e que o espetáculo foi ganhando uma forma mais definida, o que inclusive se perpetuou depois que começamos a apresentá-lo ao público [...] Denise já me mostrou um esboço corporal do que posteriormente veio a ser a partitura física do espetáculo [...] Parece que ela, como performer, ao escrever um texto, já intui um caminho de materialização no corpo da energia presente nas palavras" (apud PRADO, 2002, p. 28, grifo nosso).

A "dramaturgia essencial” (assim denominada a dramaturgia construída dentro dos preceitos do Teatro Essencial) começa a ser urdida com os ensaios, que funcionam como organizadores de células de ações, conteúdos dispersos, seqüências de movimentos, discursos e depoimentos em estudo que buscam ser direcionados para uma forma espetacular. O roteiro ou partitura cênica começa a surgir nesse momento e vai sendo ampliada com outros elementos plásticos, vocais, corporais, sonoros etc., que vão encontrando o seu lugar no trilho que vai sendo traçado. A idéia de partitura é encontrada também no fazer de outros criadores:

[...] desenho dos movimentos em Meierhold; plástica em Vakhtângov; atmosferas em Tchékhov; harmonia global em Craig; frases corporais em Dalcroze; hierarquização das partes do corpo em Decroux; gestus e os materiais registrados nos "livros de direção" de Brecht; precisão da linguagem em Artaud; partitura em Grotóvski, Schechener e Barba; visual e acoustic score em Bob Wilson; forma plasmável em Peter Brook - buscam definir e/ou modelar fisicamente elementos palpáveis, controláveis e reproduzíveis no trabalho com o ator. (BONFITTO, 2002, p. 80, grifo do autor).

E no processo do "performer essencial" ela nunca é prévia, concebida intelectualmente para depois ser executada. O seu corpo, sua voz e suas idéias antecedem o roteiro, a palavra escrita, as marcações. Mesmo com as apresentações ela continua sendo modificada, como uma matéria flexível, suscetível à incorporação de outros elementos que porventura surjam no contato com a platéia. É certo que não podemos deixar de traçar uma linha evolutiva desse tipo de abordagem até as experiências de Stoklos com criação coletiva na década de 70 . 
Para deflagrar o aparecimento dos elementos a serem partiturados, o "performer essencial" se mantém num estado permanente de autopercepção, em contato com a suas reminiscências, os seus conteúdos pessoais. Como indício desse processo temos uma declaração de Stoklos quando da sua residência no teatro La Mamma, em Nova Iorque, em 87: "Eu ficava me exercitando e me perguntando o que eu queria fazer. $\underline{\text { Com exercícios e }}$ treinos fui chegando a Mary Stuart, texto que eu conhecera três anos antes e já havia adorado" (JT, 07/04, p. 18, grifo nosso). A manutenção de uma prática de treinos e exercícios corporais e vocais constante, mesmo quando não se está ensaiando, possibilita que o mundo interior do performer encontre correspondências na sua corporeidade. Em uma outra entrevista ela deixa muito mais claro este caminho: "A forma de criação é estar em contato com o material que eu tenho dentro de mim [...] com meu vazio imenso, com memórias, temas que se misturam a impulsos que são reproduzidos na dinâmica da cena" (apud NÉSPOLI, 16/03/1999, p. D 6, grifo nosso). A construção do trabalho se dá nessa "fricção" incessante, no qual inexistem intercalações de fases, isto é, não se prepara tecnicamente o corpo para depois se tratar do tema, ou vice-versa.

A dinâmica do processo de criação imbrica-se com o cotidiano, não existindo separação entre arte e vida. Constrói-se uma trajetória extremamente apoiada na expansão da idiossincrasia, ao se colocar em percepção permanente de si mesmo, utilizando-se de referências e contextos (intra)pessoais na busca de co-relações com conteúdos extrapessoais, à espera do que poderíamos chamar de um "gatilho disparador". Não existe dessa forma um ponto de partida determinante para a criação de um solo, o que existe é a manutenção de um estado de percepção e atenção, tanto consigo mesmo para perceber quando um processo em gestão está pronto para ser formalizado, quanto para com o mundo, localizando fatos e situações que podem vir a se tornar canalizadores desse processo de formalização. Por exemplo, no caso de Calendário da Pedra foi um poema, mas poderia ser a relação humana com os objetos domésticos, como em Casa, um mito grego como em Des-Medéia, um fato histórico como em 500 Anos - um Fax de Denise Stoklos para Cristóvão Colombo.

Vozes Dissonantes (1999), foi a resposta às comemorações dos 500 anos de descobrimento do Brasil. Nesse espetáculo, em vez de tecer loas aos grandes heróis da pátria, é dada voz aos brasileiros que lançaram um olhar crítico ao país em algum momento 
da história, e que por destoarem do coro dos contentes foram "abafados". Mas a "gestação" de Vozes Dissonantes começou de fato dois anos antes, em conversas com pessoas, garimpando textos e relatos, numa intensa pesquisa onde foi se revelando a história de pensadores, artistas, filósofos, escritores, poetas, enfim, brasileiros; alguns ilustres desconhecidos que se levantaram contra injustiças e opressões.

Contudo, pode-se pensar no espetáculo como uma das erupções de um processo que teve início em 1992, com o solo 500 Anos - um Fax de Denise Stoklos para Cristóvão Colombo, cuja temática também era o descobrimento. Sob uma outra ótica, ambos os espetáculos giravam em torno de questionamentos sobre a identidade, que remonta aos espetáculos encenados após o retorno do exílio em Londres. O intuito com Vozes Dissonantes, em meio ao clima de celebração, era de instalar um clima de revolução, de descontentamento, de passar a limpo os incidentes da história, objetivo similar quando da feitura, oito anos antes, de 500 Anos - um Fax de Denise Stoklos para Cristóvão Colombo. Ou seja, são conteúdos que retornam, que aguardam o "gatilho" para ganhar uma forma espetacular.

Vozes Dissonantes expõe um aspecto muito recorrente na produção do Teatro Essencial: a utilização da história oficial, do propagado senso comum a respeito dos fatos históricos, para uma revisão crítica. Vamos encontrar isso nos solos Denise Stoklos in Mary Stuart, no já citado "Fax", Desobediência Civil, e se considerarmos a dimensão simbólica que o fato histórico alcança no inconsciente da coletividade, Des-Medéia e Hamlet em Irati também passam por essa mesma abordagem.

Estruturalmente, os fatos históricos são apresentados por meio de discursos, ou digressões, nas quais alternam-se seriedade e ironia. Esses discursos podem vir na forma de uma narração ou citação de um fato, de uma situação ou de um personagem (histórico, como nos exemplos acima, ou cotidiano, ou autobiográfico, ou ficcional), ou na combinação de todos esses. Em Vozes Dissonantes, por exemplo, textos de personalidades como Gilberto Freire, Dom Hélder Câmara, Hélio Pelegrino, José Bonifácio, Milton Santos, Euclides da Cunha, Pe. Antônio Veira são apropriados, e ganham a autoria do "performer essencial” ao fazerem parte da sua encenação, como vemos na transcrição da cena a seguir: 
“- Em 22 de abril de 1.500, Pedro Álvares Cabral descobriu o Brasil!”

Enquanto diz a palavra descobriu, segurando um grande tecido imaginário espalhado pelo chão do palco, faz a mímica de descobrir o chão (Brasil):

"- Quando Cabral descobriu o Brasil, já haviam pessoas vivendo aqui." Simulando o espanto de Cabral:

"- Pô, tá ocupado!"

E Denise dirigindo-se à platéia, explica:

"- Cabral trabalhava para uma organização religiosa,"

Quando ela diz a palavra religiosa, o faz com ênfase e esfrega os dedos em sinal monetário:

"- na qual o Papa tinha a jurisdição religiosa sobre o Novo Mundo."

Então, mudando de atitude:

“- Cabral pega o seu celular e liga para o quartel-general em Lisboa!”

Usando um celular imaginário:

“- Pessoal, a gente tem um problema! Aqui é habitado! Não podemos descobrir!"

Para a platéia:

"-O rei responde:"

Simulando o rei:

"-O que é isso Pedrão! Mata todo mundo [...] Ah, é?"

Com ênfase:

"-Dóceis e gentis? As mulheres todas nuas? Hum [...]"

Coçando a barriga de forma zombeteira:

“- Cabral, você levou a cruz, a sagrada Cruz? Você não levou a cruz, Cabral!? O logo da companhia! Mas não tem problema, o Brasil ainda não foi registrado.”

“- Então o rei ordena a Cabral que faça uma grande cruz com Pau-Brasil, converta os índios e ensine-lhes o básico do português: "Sim senhor.", "Por favor.", e "Meu Deus."

E Denise conclui:

“- E teve início o pesadelo sem fim, no qual esta terra pode ser de qualquer um, mas nunca de si mesma" (RAMIREZ-CANCIO, 2001, documento eletrônico tradução nossa).

Em geral o material textual utilizado na confecção dos solos não é proveniente de fontes dramáticas (e quando provém, a escolha recai sobre a temática). Os textos são retrabalhados em ação, no improviso, na execução, passando por um processo de apropriação, de estilização, resultando em discursos que assumem a função de depoimentos ou denúncias. Nesse processo busca-se constantemente, com o corpo e com a voz, estabelecer conexões entre épocas, lugares, pessoas, eventos, situações, referências, tornando a narrativa atemporal, para levar o espectador a uma conscientização crítica.

É muito claro na cena transcrita acima o emprego do discurso na atuação do solista ao se dirigir à platéia, que remete às apresentações humorísticas no estilo One-Man Show, aos números de cortina do Teatro de Revista, aos contadores de histórias e suas narrativas épicas. Percebem-se os índices de intervenção introduzidos no fato e nas personagens históricas, que indicam a autoria do "performer essencial", por meio da linguagem coloquial, do uso anacrônico dos objetos, da paródia, da caricatura, da mímica que descreve 
situações e ambientes. O encadeamento das ações, dos gestos contraditórios, das entoações da fala, das mudanças posturais e dos comentários estabelece uma progressão cômica que, ao contrário do que se espera de uma piada, resulta num desfecho trágico, cujo intuito é levar o espectador a uma reflexão crítica.

Se o fato, situação, ou personagem merecem reverência ou respeito, a apresentação do mesmo se faz num tom arrebatado e solene, sem caricaturas, tanto no tom de voz, profundo e vibrante, quanto no corpo, altivo, ereto e orgulhoso. Aos demais reservam-se as zombarias, os chistes, a fala histriônica, o grotesco, a careta:
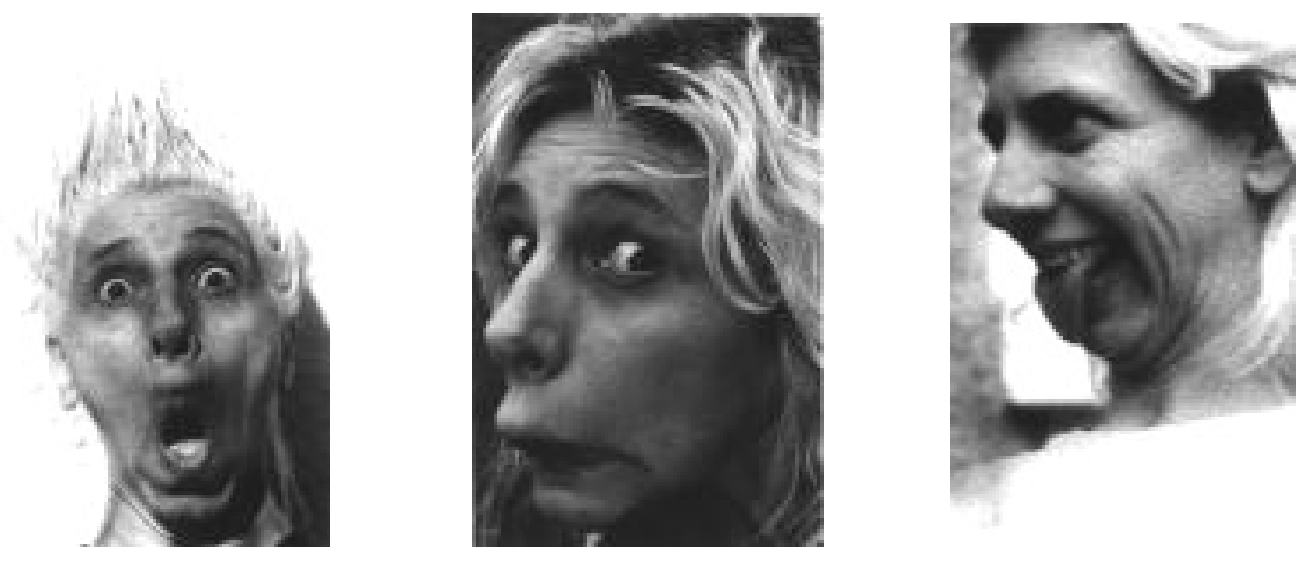

Ao aproximar o público do assunto em discussão dessa maneira, sem criar um processo empático que nublaria a consciência desperta, cria-se uma perspectiva de observação sempre externa. A meta é solapar o mito da verdade histórica, isto é, a crença de que os fatos estão referendados e não lhes cabe contestação. Justaposições, colagens, apropriações, citações, reproduções são procedimentos empregados para construir esta "dramaturgia espetacular". Ao se apropriar de narrativas históricas, mitológicas, ficcionais, ou autobiográficas procura-se destruir as coordenadas de tempo e espaço, internas à narrativa e que a sustentam como verdade, situando o contexto da narrativa fora da dinâmica da realidade.

Como a estrutura da narrativa cênica é fragmentada, é possível justapor qualquer fato a qualquer outra coisa, às vezes citando ou colando, outras fazendo interferências no material textual e recontando ao seu modo. $\mathrm{O}$ uso desses processos acarreta o aparecimento de uma "linguagem gerativa ao invés de uma linguagem normativa: a linguagem normativa 
está associada à gramática discursiva, à fala encadeada e hierarquizada [...] a ruptura desse discurso, através da collage, que trabalha com o fragmento, entra num outro discurso, que tende a ser gerativo (no sentido da livre-associação)" (COHEN, 1989, p. 60).

O deslocamento causado pela justaposição expande os significados, redefine, ou anula o mundo evocado. A narrativa assim apropriada é apresentada no aqui-e-agora do tempo e do espaço do espectador, isto é, na atualidade de sua realidade, pois o espaço e o tempo cênicos não são estruturados para remeterem-se ao contexto ficcional da "realidade da narrativa". À platéia só resta acompanhar o dinamismo das evoluções, alternâncias e transformações da plasticidade do corpo e da voz, bem como do raciocínio, do "performer essencial", pois é o "colador que passa a ser o elemento preponderante do processo" (COHEN, 1989, p. 60) de conduzir o público a uma experiência diferenciada para com as narrativas tidas como absolutas, verdadeiras e imutáveis.

Tomemos como exemplo uma cena de Denise Stoklos in Mary Stuart, na qual Mary Stuart/Denise Stoklos faz um discurso inflamado em sua própria defesa, em conseqüência da condenação imposta por Elisabeth I:

[...] "-Declaro que como soberana absoluta de um país estrangeiro,"

Ela está de pé, diante da cadeira, presa na cela.

“- porque eu sou estrangeira!"

Bate no peito:
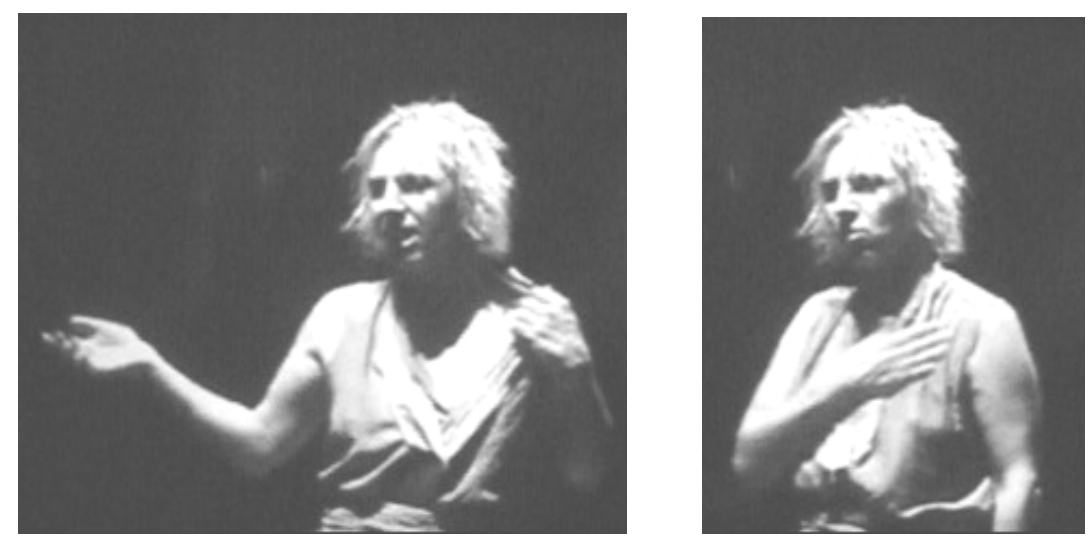

“- Eu hei de procurar a proteção dos meus parentes,"

Faz mímica de que está lutando boxe. "- os soberanos de França! Meus parentes, os soberanos de Espanha! Para que me tirem dessa prisão injusta!” 

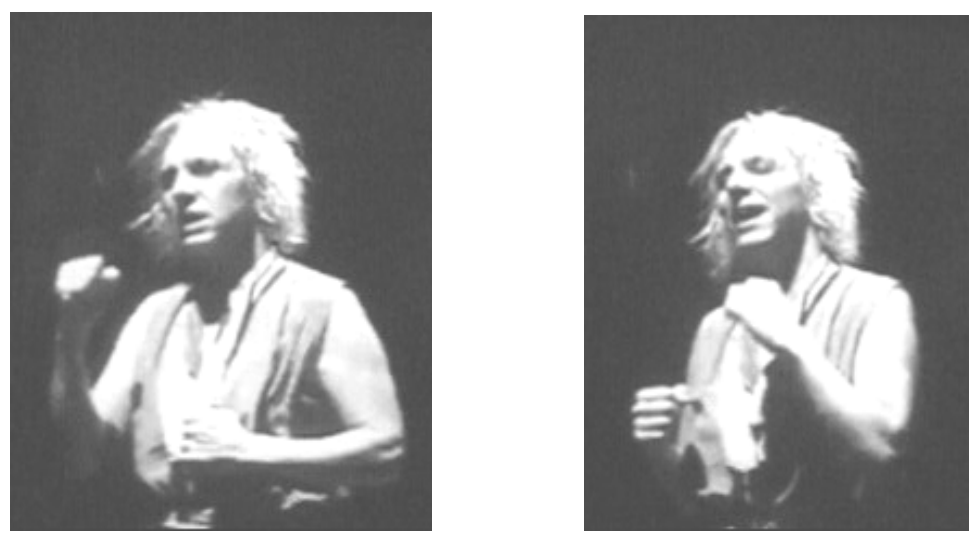

Num movimento rápido senta-se na cadeira:

"- Aí me perguntaram na entrevista, o que é que eu pensava!"

O tom de voz deixa de ser inflamado e solene, passa a ser frívolo e cotidiano, não se percebendo mais traços de Mary Stuart. O gestual de boxear de antes, decidido, objetivo e combativo, deu lugar a um movimento disperso de enrolar e desenrolar a barra da calça.
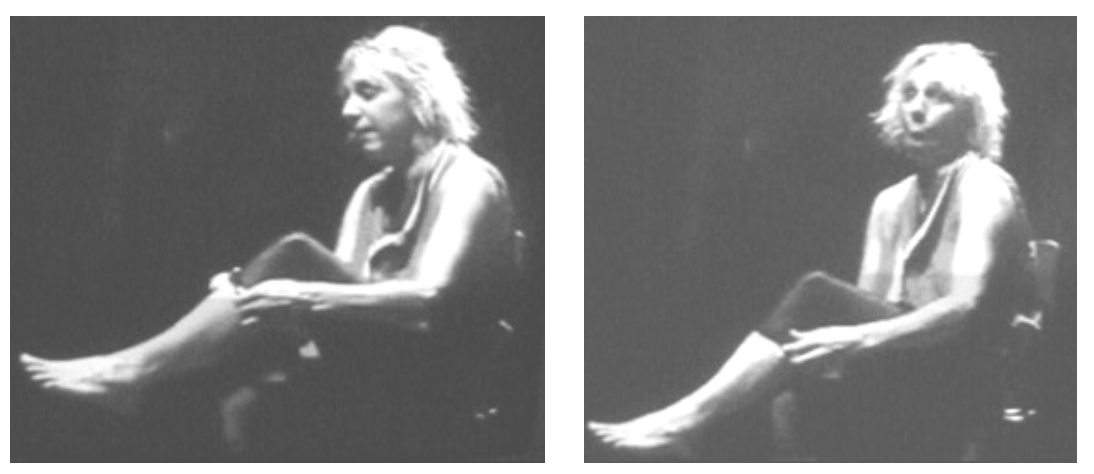

- "Eu nem sei o que eu pensava, porque eu humqxscidnfbcvgfsmfn [...]"

Não se entende o que ela fala, entabula uma conversa consigo mesma da qual só se ouvem grunhidos e balbucios:
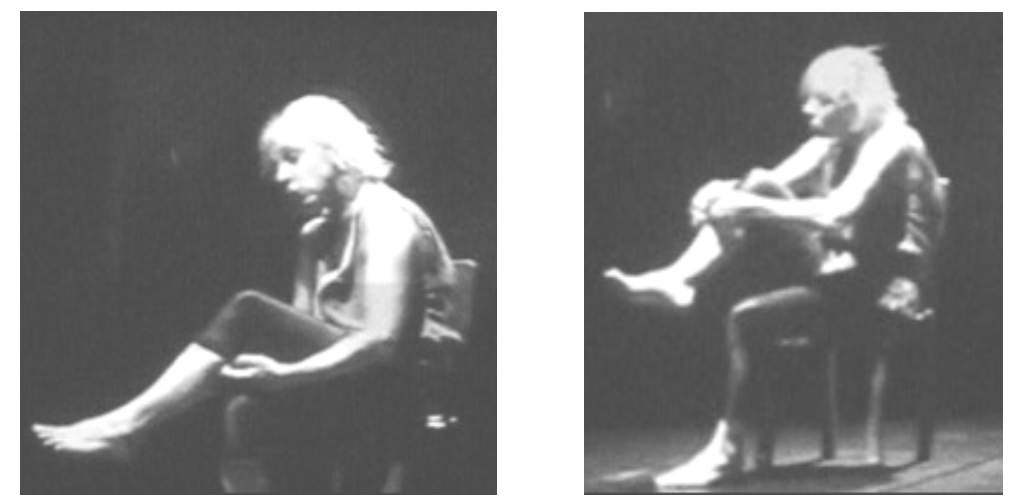
Faz uma pausa e dirige-se a platéia:

“- Vocês estão entendendo o que está acontecendo aqui?"

A indagação é feita num tom irônico.

"- Por que não é pra fazer sentido mesmo!"

Enrola o cabelo com um ar zombeteiro. O corpo tem uma postura apatetada.
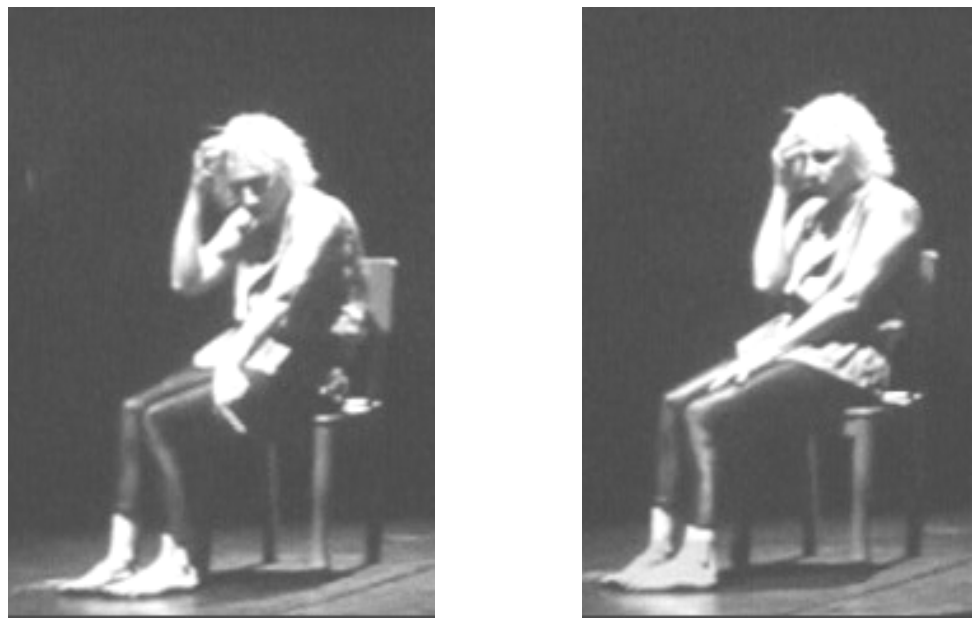

“- Porque há tantas coisas na nossa sociedade, hoje, que não fazem sentido, que é por isso que tem essa cena que não faz sentido!"

Numa pausa cômica:
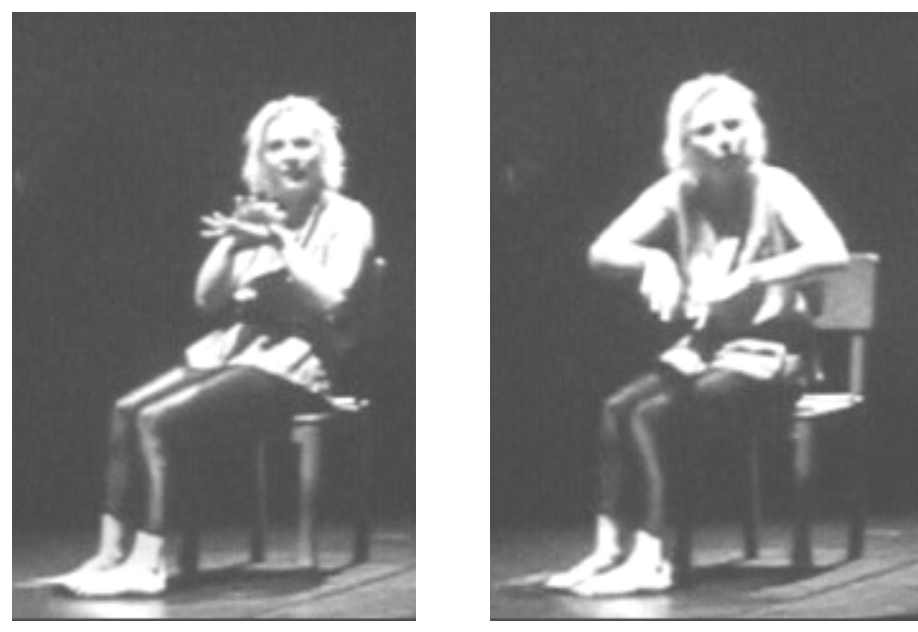

“- Porque todos mandam neste país, todos mandam, menos os inteligentes!" Pausa cômica. Começa a contar nos dedos, balançando a mão, e o gesto vai se transformando num gesto obsceno. $\mathrm{O}$ fim da frase se transforma num grunhido: “- Os presidentes mandam, os governadores mandam, os deputados mandam, e a gente só toma no hrandtiopn [...]" 

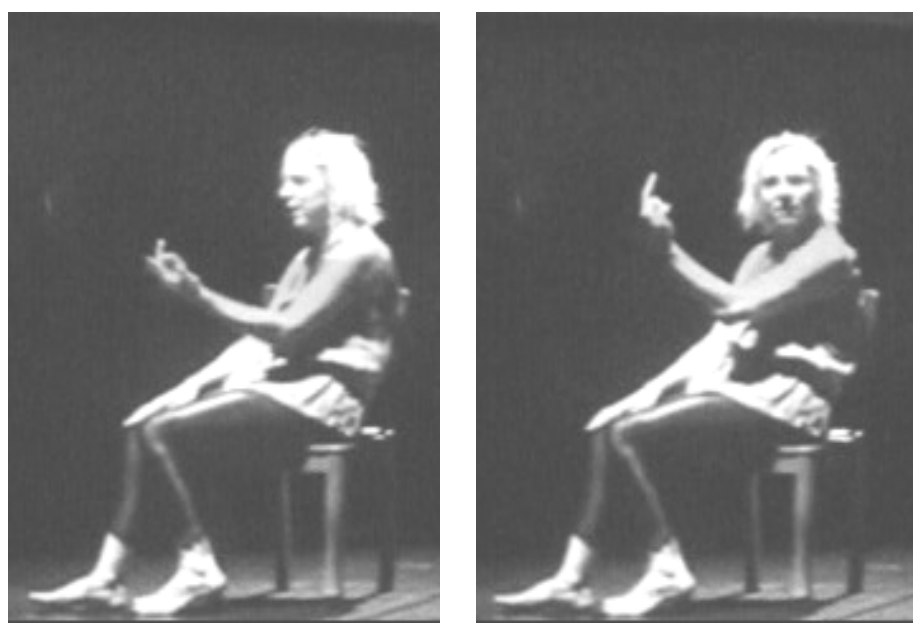

Tomando um impulso, ela se levanta da cadeira, e volta exatamente ao mesmo ponto de antes da quebra, como Mary Stuart. - "Para que me tirassem desta prisão indigna! [...]":
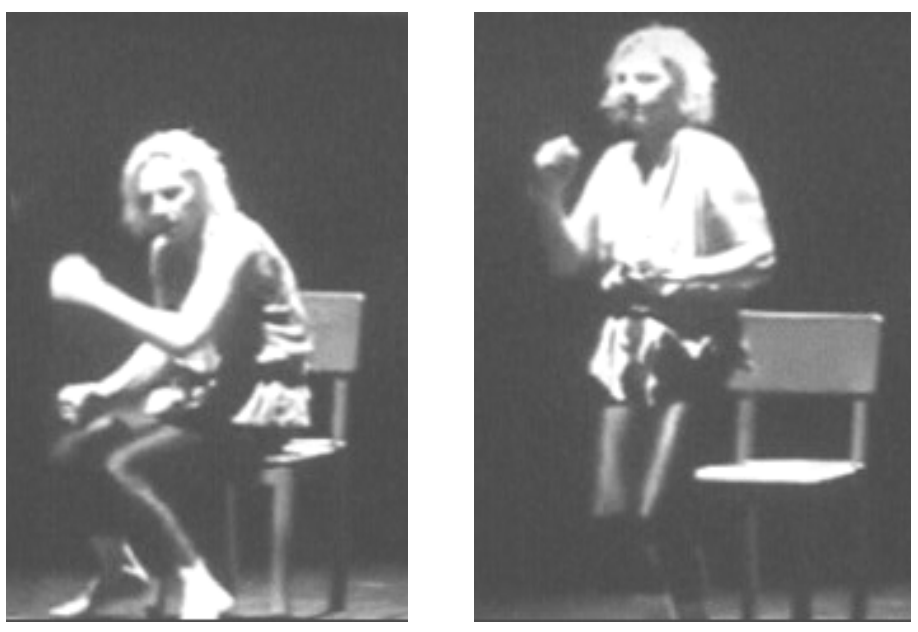

(Citação nossa).

Novamente temos aqui, em Denise Stoklos in Mary Stuart, todos os elementos dramatúrgicos por mim já analisados anteriormente ao tratar de Vozes Dissonantes neste capítulo: a dinâmica da alternância na apresentação dos fatos e personagens históricas, que entre momentos cômicos e dramáticos busca a reflexão crítica do espectador; a utilização do discurso que borra a distinção entre o performer e o personagem que ele apresenta; a destruição das coordenadas de tempo e espaço que sustentam a verdade histórica como meio de aproximação da atualidade para causar reflexão do espectador. 
A "dramaturgia essencial" se utiliza de justaposições, colagens, apropriações, citações e reproduções, organizando um roteiro ou partitura cênica que começa a ganhar urdidura nos ensaios e vai sendo modificada, como uma matéria flexível, no contato com a platéia. A dinâmica do processo imbrica-se com o cotidiano, não existindo separação entre arte e vida, levando o "performer essencial" a se manter num estado constante de autopercepção consigo mesmo e assim conseguir captar os elementos que farão parte da dramaturgia espetacular.

Um evento, uma imagem, uma música, um fato ou uma lembrança tornam-se detonadores da criação do processo de fomalização espetacular. As referências e contextos pessoais encontram na temática o caminho para a metaforização do material textual, retrabalhado em ação, no improviso, na execução, sofrendo intervenções que resultam depoimentos autorais do "performer essencial".

Como vimos, as idealizações teóricas preconizadas nos manifestos, textos e declarações assumem uma complexidade na encenação do "solo essencial", devido principalmente ao rigor da limitação dos elementos cênicos, que concentra toda a carga referencial na figura do atuante e nos solitários objetos de cena. Contudo, é a ação humana que dinamiza esse contexto austero, introduzindo humor e crítica, reflexão e otimismo, consciência e prazer na busca pela sua transformação e reconfiguração. O "performer essencial" é o pilar de sustentação desse teatro, e vasculhar os caminhos engendrados para a sua atuação solista á desvelar o cerne do Teatro Essencial. 
Capítulo 3

O Performer Essencial 


\subsection{As Sementes.}

"Performer essencial", como já dito anteriormente, é o termo empregado para nomear aquele que atua dentro dos princípios do Teatro Essencial. A pessoa do atuante é o epicentro do acontecimento cênico e dela partem todos os vetores que organizam a "cena essencial", e por mais que existam elementos cenográficos, textuais, sonoros etc., o foco estará sempre na dramaturgia concebida por ele, ao organizar seus aspectos corporais e vocais, que são únicos no espaço teatral.

O termo ator seria inadequado para o tipo de atuação empreendida aqui pela sua conotação, isto é, de estar hierarquicamente submetido à batuta do diretor e do texto dramático, sendo-lhe negada então a soberania sobre a criação artística, pelo primeiro, e a afirmação da sua idiossincrasia, pelo segundo, ao impor-lhe as características da personagem para que sejam plasmadas o mais perfeitamente possível pelo seu corpo.

Terminologias, como por exemplo, ator-criador, que admite "a dramaturgia do corpo do ator como cerne da criação teatral [e] o fim da dicotomia autor/ator" (LOUIS, 2005, p. 4), ou ator performático, que "incorpora no vocabulário da ação a releitura dos atos e do tempo segundo a interação com o público" (GUSMÃO, 2000, p, 52), apesar de reunirem princípios considerados como fundamentais no Teatro Essencial, não dão conta da precisão do trabalho desempenhado pelo atuante, ou seja, acrescentar apenas um índice ao termo ator, mesmo que delimite o seu fazer, não exclui a possibilidade da criação mimética de papéis - "o performer realiza uma encenação de seu próprio eu, o ator faz o papel de outro" (PAVIS, 2001, p. 285).

Dentro do atual movimento teatral, em favor da participação mais significativa e diversificada do ator no processo de criação, as propostas de Denise Stoklos se afiguram como um caminho, com especificidades próprias, que apontam para procedimentos de construção de uma encenação a partir de si mesmo. Neste capítulo vamos tentar aprofundar o mapeamento dos procedimentos técnicos empregados pelo "performer essencial" na constituição de um sistema de atuação pessoal.

Para alcançar este intento a pesquisa se volta agora, primeiramente, para os exparticipantes do projeto Solos do Brasil, uma iniciativa empreendida por Denise Stoklos 
em abril de 2002, em São Paulo, cujo objetivo era estabelecer um núcleo de pesquisa teatral voltado para a investigação do trabalho do ator e o aproveitamento máximo de seu potencial criador, segundo as diretrizes do Teatro Essencial. Na segunda parte do capítulo a atenção recai sobre o ator carioca Marcos Americano, que partindo da observação dos espetáculos de Denise, leituras de seus textos, e de uma convivência próxima, após duas décadas, estreou em 2006, no Rio de Janeiro, o solo Dia dos Loucos, reconhecido por Stoklos como estruturado segundo as linhas do Teatro Essencial. 


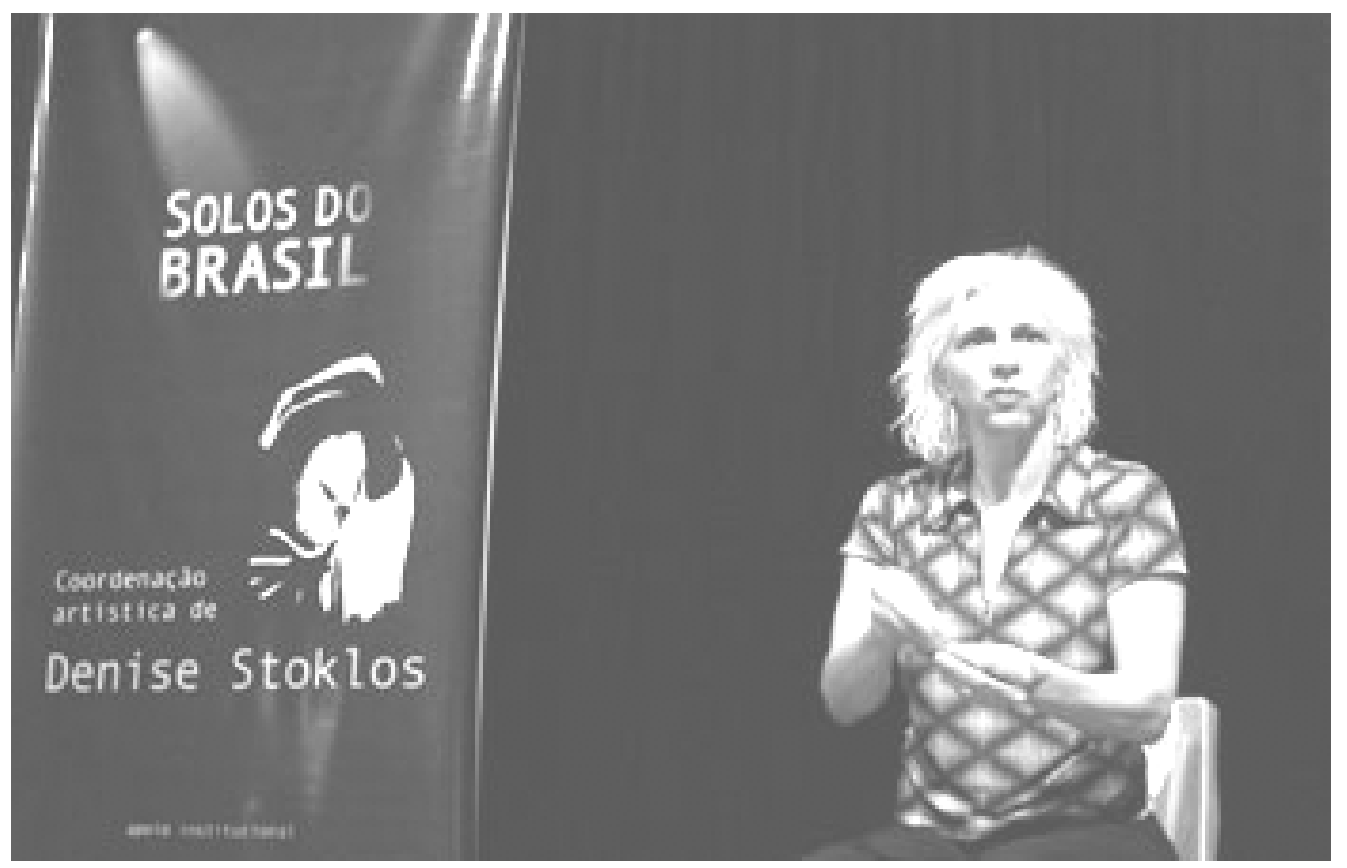

Solos do Brasil. 


\subsection{Solo Brasileiro I.}

Impulsionada pela solicitação constante das pessoas em dividir o conhecimento das bases de sua prática, Stoklos iniciou a concepção e a elaboração do projeto Solos do Brasil em 2001, um ano antes do começo propriamente dito. A idéia foi fruto das experiências de ministrar aulas sobre os princípios do seu fazer teatral, em 1999, numa oficina de uma semana no SESC Ipiranga - São Paulo, e em 2000, como convidada pelo Departament of Performance Studies - New York University, das palestras sobre o Teatro Essencial aos pós-graduandos da cadeira de Performance Composition.

O projeto teve o patrocínio da Petroquisa, que investiu cerca de $\mathrm{R} \$ 1.000 .000,00$, e apoio do SESC e da Secretaria Municipal de Cultura de São Paulo. O desejado era selecionar atores de todo o país, sediá-los em São Paulo, oferecer-lhes uma remuneração, treiná-los por um período e apresentar um espetáculo de conclusão. A duração foi de 11 meses, do início de abril de 2002 até o início de março de 2003, sendo que até dezembro foi a fase de pesquisa e nos três últimos meses a fase de apresentação. A fase de pesquisa concentrou-se nos cinco a seis primeiros meses na potencialização do aparato psicofísico e no levantamento de material a partir de contexto pessoal. Os meses finais da primeira parte foram destinados aos ensaios dos solos que seriam apresentados logo após, numa temporada de três meses (fase de apresentação).

A seleção dos participantes começou no início de 2002 e foi feita primeiramente por carta de interesse e currículo. Dos 2.000 candidatos da primeira parte, foram selecionados 600 que disputaram 15 vagas. O processo de seleção da segunda etapa foi no Teatro João Caetano, em São Paulo, e constava de uma apresentação individual curta:
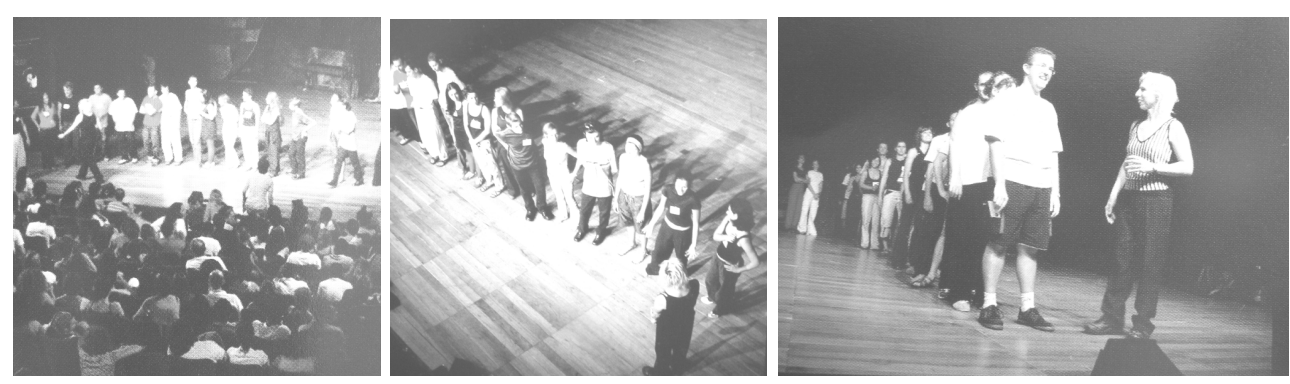
Foi alugada uma casa, como sede, no bairro do Ipiranga, pela proximidade com o SESC Ipiranga, já que as aulas aconteciam nos dois espaços, de segunda a sexta-feira, todas no período da manhã. A casa servia de local para ensaios, estudos e moradia para os selecionados que residiam em outros estados. Cada selecionado recebia uma ajuda de custo por mês de $\mathrm{R} \$ 1.500,00$ durante todo o tempo de duração do projeto.

Segundo o que se pretendia, esses alunos foram instigados e orientados a incorporar os preceitos básicos de atuação de um "performer essencial”, ou seja, o uso de um mínimo de elementos cênicos, a exploração máxima do potencial do corpo e da voz, e a total liberdade e responsabilidade por toda a concepção e criação do seu solo. Como resultado final cada um teria um espetáculo, onde além de atuar, cada um assinaria a própria direção, coreografia, figurino, dramaturgia e sonoplastia.

O tema que orientou a pesquisa de cada aluno foi "O Brasil" e o objetivo era posicionar cada aluno diante da complexidade das diversas questões que envolvem a cidadania brasileira, levando-o a uma reflexão e investigação crítica, para que cada um pudesse conceber um material artístico de qualidade e devolvê-lo à coletividade para uma reflexão conjunta.

Houve ainda a preocupação com a documentação e divulgação dos resultados obtidos ao longo do processo por meio de um sítio na Internet, um fórum eletrônico de discussão, aulas e ensaios abertos, e debates com a comunidade. Com a participação do público em geral esperava-se ir além de simplesmente se montar um espetáculo, pois o seu feed-back realimentaria as discussões do grupo de pesquisa e o tornaria co-criador dos solos que seriam apresentados. A supervisão geral e coordenação artística ficava a cargo de Denise Stoklos, que contou ainda com o auxílio de oito professores assistentes na condução do processo:
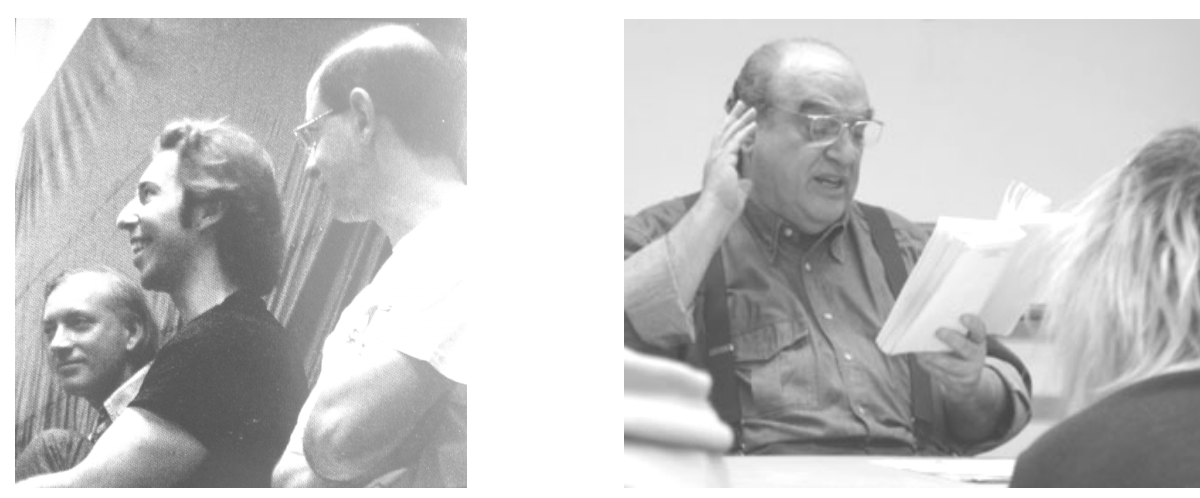
A fase final do projeto compreendeu as apresentações públicas dos solos desenvolvidos pelos alunos. As apresentações duraram dois meses, de terça-feira a domingo, no Centro Cultural São Paulo. Divididos em quatro grupos, os alunos mostraram seus solos revezando os dias das apresentações.

A preparação de um performer basicamente apóia-se em três instâncias: no incremento do seu aparato psicofísico, o que significa uma expansão do seu potencial idiossincrático; a exacerbação da sua presença, que garante a prontidão em lidar com as solicitações do espaço e do público; e o contato mais profundo consigo mesmo, estabelecendo um alargamento do contexto pessoal, que é o seu arcabouço para as suas narrativas, suas figuras, seus mitos (COHEN, 1989, p.100-101).

Para dar conta dessas diretrizes, era de fundamental importância reunir um grupo de alunos com um "physique-du-rôle não só físico, mas existencial" (COHEN, 1989, p. 102), já que processos que lidam com contexto pessoal, caracterizados "por uma extrojeção (tirar coisas, figuras suas) ao invés de uma introjeção (receber a personagem)" (COHEN, 1989, p. 101, grifo do autor), solicitam em demasia a imbricação dos conteúdos autobiográficos e pessoais aos ficcionais, exigindo um permanente exercício de estimulação que não se restringe a sala de ensaios e invade todas os aspectos da existência do performer.

Ao que parece a seleção por currículo não foi a mais preponderante, já que a formação dos que foram finalmente escolhidos era das mais diversas, abrangendo tanto o autodidata, Vinicius Piedade, quanto a ex-professora universitária Tiche Viana. Somos levados a suspeitar que a carta de intenção foi usada como um instrumento de melhor aferição, na busca do perfil mais adequado aos trabalhos que lidariam com o desenvolvimento das habilidades psicofísicas e "extrojeção" de conteúdos particulares:

\footnotetext{
Eu percebi que a seleção ia começar lá na carta de intenção. Todo o dia eu lia, escrevia, reescrevia, e pensava no que eu realmente queria dentro desse projeto, porque eu sempre fui, claro, fã da Denise [...] Ficou muito forte, já tinha o Teatro Essencial na minha carta de intenção, só fui descobrir isso muito tempo depois. Mas, a minha carta de intenção, em si, ela já vibrava. Ela tinha já o teatro, o desejo pela verdade... pelo teatro puro, essencial. Aí eu mandei essa carta de intenção e vi que tinha sido selecionada para a segunda fase. Fiquei toda feliz! (Simone Faro, entrevista).
}

Se todos os pré-selecioinados, como exemplificado acima, já emanavam em suas palavras escritas uma determinação, um posicionamento claro e objetivo, uma força, uma 
presença necessária no que "diz respeito à capacidade de mobilização do público" (COHEN, 1989, p. 101), só seria preciso avaliar a sua idiossincrasia:

Então cada um que subir lá no palco vai ser di-fe-ren-te! Vai ser in-te-res-san-tíssí-mo ver cada um! Cada um vai lá fazer a mesma cena: "Meu nome é fulano de tal!". Só isso: entrar, falar e fazer um gesto. Só isso é um teaaaatro espetacular! Cada um tem uma PRE-SEEENÇA: um jeito, uma vida, uma personalidade, uma originalidade... um único EU! (STOKLOS, entrevista).

Presença aqui é sinônimo de individualidade, o que significa que a grande tarefa daquele que deseja ser um "performer essencial" é reconhecer, explorar e exacerbar o que faz dele um ser único no universo. Numa certa medida, toda e qualquer pessoa está capacitada a vir a se tornar um atuante nesse teatro. Provavelmente, devido ao tempo de duração do projeto, a seleção deve ter então priorizado aqueles em que o emprego dessa pessoalidade de forma espetacular estivesse mais adiantada, resultando numa avaliação bastante subjetiva.

Seria necessário que ele já conseguisse atrair, ser notado pelo público, conservar essa atenção, e fazê-lo se concentrar apenas no tempo presente da cena. Alguns chamam a isso de energia, palavra repleta de significados místicos e contraditórios, mas talvez possamos simplesmente dizer que a procura era pela presença viva do humano, que antes de qualquer movimento, atividade ou ação para o mundo exterior, manifesta-se na qualidade que nos torna vivos.

E aí ela reuniu todo mundo no Teatro João Caetano [...] apesar de ter o material, ela preferia olhar no olho das pessoas e falar com as pessoas. E de uma certa maneira ver as pessoas. Então ela convocava grupos, aí você ia lá na frente, e falava com aquela platéia... Acho que de uma certa maneira o que a Denise procurava entender naquelas pessoas era o comprometimento de cada um com o seu estar ali diante do outro. Naquele momento não era tão claro, mas anos depois, talvez com o distanciamento de olhar pra trás e enxergar cada momento daquele processo (Tiche Viana, entrevista). 


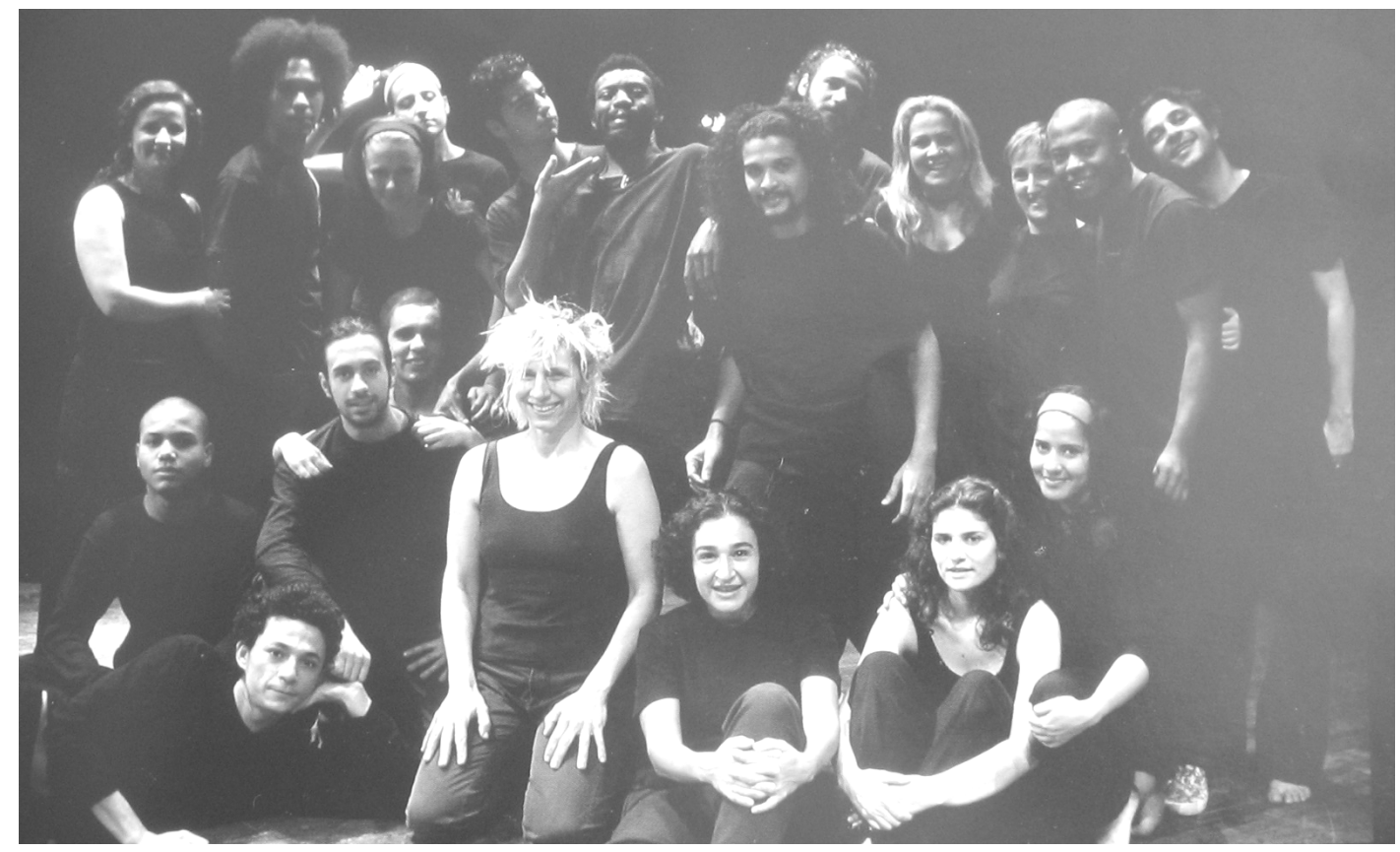

Solos do Brasil 
Mapeando alguns pontos do projeto Solos do Brasil, podemos perceber como essas questões foram tratadas pela instrumentalização do "performer essencial". Para o "desenvolvimento de suas habilidades psicofísicas" (COHEN, 1989, p. 100) - habilidade aqui entendida como uma capacidade de exibição quase que virtuosística -, poderiam ser escolhidas técnicas diversas, porém, creditando-se muito a isso a formação corporal de Stoklos em mímica, o treinamento conformou-se da seguinte forma:

\begin{abstract}
A gente estava tendo contato com todo o instrumental que seria necessário para a formulação deste ator [...] como é, quais são os elementos que ele utiliza para constituir o Teatro Essencial. Então eu considero toda a primeira parte como uma parte instrumentalizadora... Eram aulas basicamente centradas no corpo, a gente sentiu a ausência de um trabalho vocal, embora tivesse música, canto... E aí dentro do trabalho corporal muita coisa centrada na questão de um trabalho físico, de uma dinâmica física, centrada na mímica. (Tiche Viana, entrevista).
\end{abstract}

As aulas de mímica ficaram a cargo do professor Luis Louis. O professor Eduardo Coutinho foi convidado por Stoklos para trabalhar Texto Corporal. Seu contato com ela vem desde 1982, quando, recém chegada de Londres, foi seu aluno num dos cursos de mímica ministrados no SESC Pompéia. Apesar de ambos terem sido convidados para trabalhar conteúdos diferentes, Eduardo Coutinho, catedrático na mesma linguagem que Luis Louis, entende o convite da seguinte forma:

\begin{abstract}
A mímica objetiva é a ilusão, chama-se técnica ilusória, a subjetiva é a expressão. A Denise usa pouco da técnica ilusória, mas a base de linguagem dela é mímica... Daria pra dizer que o Teatro Essencial seria um desdobramento pessoal do que ela fez da mímica. Por isso que eu estava lá [...] Porque, as técnicas estavam sendo dadas pelo Luís Louis... e o que eu estava fazendo lá? Mímica! Só que não as técnicas objetivas, da mímica objetiva, da divisão do corpo... eu ia direto pra linguagem. A minha idéia era de falar sobre a mímica enquanto linguagem, não enquanto técnica, que era essa coisa de consciência corporal. [...] eu comecei com um trabalho de mostrar pra eles como era expressar [...] (Eduardo Coutinho, entrevista).
\end{abstract}

Nos depoimentos dos professores entrevistados foi unânime o fato de que nenhum deles foi orientado previamente sobre quais eram as habilidades necessárias a serem adquiridas pelo "performer essencial". Foi-lhes apenas solicitado que ministrassem uma disciplina específica, ficando o conteúdo livremente à sua escolha. Não houve discussão tampouco da grade curricular, estando a justificativa da sua estruturação totalmente sob os 
auspícios de Stoklos. Todavia, todos eles creditam a sua seleção de professores assistentes a algum vínculo de amizade, ou conhecimento anterior do seu trabalho:

Eu fui convidado pela Denise para dar aula de máscara neutra e trabalho corporal. A escolha foi feita a partir dela, ela praticamente se incumbiu dessa escolha [...] somos grandes amigos [...] Ela tem um trabalho que ela desenvolveu muito na mímica, que é uma coisa que eu não tenho como foco do meu trabalho. Meu trabalho é muito voltado pra área lúdica, clownesca, do humor físico, mas não da mímica. Ela me convidou, tenho a impressão, por saber que eu tenho essa formação bem concreta com Le Coq. (Ricardo Napoleão, entrevista).

Completando essa equipe, responsável pela fase de instrumentalização, temos o professor Caio Ferraz, convidado para dar aula de canto e o professor Hugo Rodas, convidado para dar aula de dança. O que transparece na grade curricular organizada para a instrumentalização das habilidades físicas do "performer essencial", é que, excetuando o professor Luis Louis, encarregado da base técnica, todos os outros direcionaram seu foco para a questão expressiva do atuante:

Acho que esses eram os dois grandes pontos de apoio: Luís Louis na questão física e corpórea e a outra coisa o pensamento, a desconstrução do pensamento e a construção do pensamento, onde a gente saía da questão da representação e entrava na questão da expressão. Essa foi a grande chave que o Fuganti trouxe e acho que um dos maiores aprendizados que a gente teve pra poder distanciar de um teatro que a Denise chamava de ficção para o que ela chama de Teatro Essencial. (Tiche Viana, entrevista).

O arquiteto e filósofo autodidata Luiz Fuganti foi convidado para trabalhar dramaturgia, pois, na visão de Stoklos, um dramaturgo tradicional iria: "ensinar como é que se faz e todo mundo ia copiar, eu chamei um filósofo pra ensinar a pensar, [...] pra daí cada um poder criar a sua dramaturgia" (STOKLOS, entrevista). Uma das habilidades inerentes ao fazer artístico do "performer essencial" é que ele acumule a função da autoria, e o processo encaminhado no projeto procurou estimular em cada aluno um sentido diferenciado do conceito ordinário de dramaturgia - um conjunto de regras que possibilitem a escrita de um texto teatral (literatura dramática), regras essas que conseqüentemente permitem a análise, leitura e interpretação do mesmo. E no pensamento de Stoklos a dramaturgia "é cada um saber pegar os elementos e como... colocar esses elementos juntos: o tema, o meu corpo, minha voz" (STOKLOS, 2007, entrevista): 


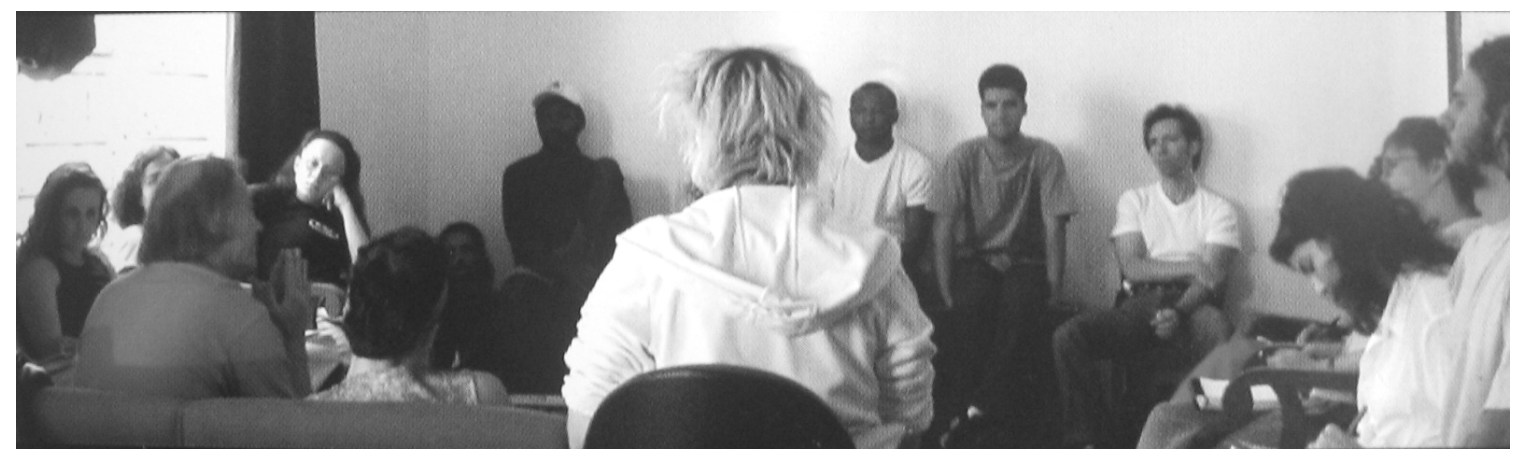

O aspecto intuitivo/intelectivo é novamente posto em relevância como responsável pela dramaturgia no Teatro Essencial. A tarefa então de Fuganti residiria em facilitar os processos de abstração, estilização e codificação na organização dos elementos corporais e vocais, atendendo ao objetivo primordial da comunicação da opinião e reflexão crítica do "performer essencial" sobre a temática geral proposta pelo projeto. Não se pode esquecer também que, neste ambiente, ideologia e estética não estão separadas, talvez híbridas ou gemelares, ou quem sabe até nem se possa distingui-las uma da outra.

Nos encontros com Luiz Fuganti o foco as discussões foi tema da expressão e da desconstrução da representação. A escolha do conteúdo das aulas não foi conseqüência de um esclarecimento das diretrizes básicas do Teatro Essencial. Houve total confiança e liberdade de escolha:

\begin{abstract}
Uma vez que ela conhecia o meu pensamento, pelo menos o suficiente para saber que eu era completamente aliado do modo dela pensar, de produzir, não houve nenhum pressuposto, nenhuma demanda nesse sentido... Eu já me sentia à vontade para propor, porque eu já sentia que era um território nômade, eu já sentia ela desconstruindo a representação, e entrando no campo da expressão [...] e sempre que entrava a representação gerava um incômodo nela mesma, e isto fazia parte, inclusive, da matéria de dramaturgia. Servia-se de uma representação para operar um desconstrução dramatúrgica. (Luiz Fuganti, entrevista).
\end{abstract}

O Teatro Essencial é assumindo claramente como um teatro não mimético, tratando-se de uma "experiência de compartilhar-se, no tempo atual de uma re-apresentação da auto-investigação, através do ator" (STOKLOS, 2001, p. 14). A tônica de todas as práticas foi a investigação dos próprios contextos pessoais, objetivando o levantamento de conteúdos, que paulatinamente tomariam o formato do discurso pessoal: 


\begin{abstract}
A vida dela é assim, é esse teatro. [...] E todos os exercícios [...] era tudo voltado pra isso: pra sua identidade, o que você vai transformar do que é seu, pra ele ser passado, pra ser público...

Os exercícios dela eram muito assim: [...] fazer a transformação desse movimento, de vários movimentos, de um passar pra outro... "Como transformar isso, como deixar de ser seu pra passar pro outro?"

A gente teve um exercício que cada um tinha que chegar lá no palco [...] então você ia lá e ela te perguntava:

"O que mais te incomoda nesse mundo, na vida, o que mais te incomoda de muito grave?"

[...] Eu, por exemplo, falei de planos de saúde [...] tanto que o meu solo foi sobre planos de saúde, comecei com essa coisa...

"Você sabe que falar isso transforma você? E como é que ele transforma o seu corpo?"

Às vezes [...] você já via a transformação do corpo [...].

E som também, depois a gente trabalhou o som.

"O que isto faz pra sua voz?" (Jô Rodrigues, entrevista).
\end{abstract}

Fuganti tratava da correspondente teórica desse processo de busca e transformação, conduzindo uma reflexão filosófica sobre as verdades apriorísticas, fomentando nos alunos uma desconstrução do pensamento - "no sentido que eles se desinvestissem de estruturas prontas, referências, verdades estabelecidas, velhas maneiras de pensar, de acreditar, de desejar, de sentir, de agir, de avaliar, de se mover, de gesticular etc." (Luiz Fuganti, entrevista) -, e que tal ação repercutiria no emprego a ser feito dos elementos corporais e vocais, ou seja, "para que os atores, a partir da sua própria matéria, matéria corpórea, inconsciente, afetiva, criassem uma performance" (Luiz Fuganti, entrevista).

No teatro aqui chamado de representação, ou mimético, o ator cria um contexto para justificar, preencher, se adequar ao contexto ficcional proposto pela literatura dramática. Fuganti identifica tal operação como mais um instrumento da sociedade de controle em que estamos imersos:

[...] a nossa vida investe em signos e investe em imagens: em signos através de discurso e imagens através de gestos e do movimento do corpo. É aí que a captura se dá. É aí que o exercício do poder se dá. O poder se exerce sobre duas superfícies: a do corpo e a do pensamento (Luiz Fuganti, entrevista).

As representações, das quais o teatro seria apenas mais uma variante, são formas de controlar e domesticar as energias do homem, de manterem as relações humanas conformadas pelas instâncias representativas. No Teatro Essencial haveria uma inversão 
desse vetor, pois seriam as palavras que encontrariam o contexto presente no próprio performer, palavras que, caso oriundas de um texto pronto, sofreriam processo de modulação ao entrarem em contato com a pessoalidade do atuante, transformando assim no seu depoimento pessoal.

No lugar de especializar o aluno na criação de contextos ficcionais, ou seja, dele "se servir de instâncias representativas, ou que representariam a essência real" (Luiz Fuganti, entrevista), o encaminhamento é estimulá-lo a criar contextos expressivos. Contudo, não se pode esquecer que essas energias humanas, essa potência informe, se expressa por meio de um corpo formatado pela cultura, e por isso, segundo Fuganti: "a desconstrução se dava na maneira como a gente se servia da linguagem, ou na maneira como a gente se serve da linguagem, e na maneira como se encadeavam os gestos" (Luiz Fuganti, entrevista).

Em resumo, a "extrojeção" do "performer essencial" ao ser (re)apresentada no palco passará por uma reconstrução sígnica, de caráter não ilusório. As etapas de espetacularização da expressão do performer, correndo pelos trilhos da "diegetização da enunciação" (PAVIS, 2001, p. 97), resultarão numa estilização bastante complexa de seu discurso cênico:

E o que eu vejo no palco? No palco eu vejo alguém que se permite, que se abre, e que incorpora erros, variações, improvisos na própria expressividade criativa. Ela (Stoklos) se serve disso. Ela se alimenta da errância dos movimentos [...]

Então ela desconstrói o gesto, ela alonga o gesto, ela acelera o gesto, ela desconecta o gesto de uma seqüência usual, ou habitual, então de repente um gesto desencadeia uma coisa inesperada.

Ela tem essas disjunções no movimento e acho que ela se aproveita bem disso. Ela cria, digamos assim, uma desarticulação do organismo humano. Eu sinto que é um teatro desarticulado, no bom sentido, de propósito ela quebra as cadeias gestuais usuais, esperadas, o organismo organizado, o organismo bem articulado. Mas o que importa é que ela faz isso também com a voz, ela faz isso também com o discurso. Então, às vezes, ela simplesmente repete uma palavra que é banal, e pelo efeito da repetição ela acaba gerando um estranhamento nessa palavra que era tão ordinária, começa a gerar um estranhamento tal que a palavra muda de sentido. E não só que ela ganha um outro sentido, ela faz o sentido variar o tempo inteiro, e os sentidos começam a pulular na superfície discursiva.

Então a emoção, o afeto, a intensidade são, digamos assim, operadores imanentes na montagem dos gestos e das palavras, no encadeamento dos gestos e das palavras.

Então a cadeia de gestos e a cadeia de palavras eu sinto que no teatro da Denise sai bem da narrativa. [...] também ultrapassa a descrição. Se ultrapassa a narrativa, ultrapassa simultaneamente a descrição e a representação. Então é um teatro expressivo. (Luiz Fuganti, entrevista). 
Mesmo não existindo uma parceria clara, pois não haviam reuniões para se discutir a interdisciplinaridade dos conteúdos, as aulas aplicadas por Denise Stoklos correspondiam, na prática, ao profundo trabalho com o contexto pessoal conduzido por Luiz Fuganti:

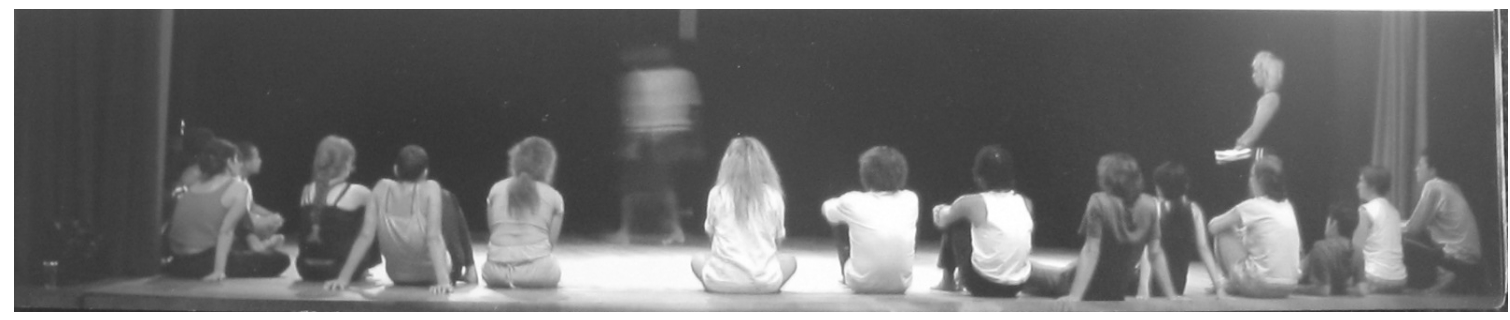

\begin{abstract}
A Denise quando iniciava um trabalho, ela achava que o estado era uma coisa que você tinha meio que acionar, automaticamente ele estava à sua disposição. Porque às vezes ela chegava e propunha um trabalho que já era uma improvisação. Era entrar e fazer. Você não precisava muito se preparar. Sem alcançar esse estado a dramaturgia não funciona, não funciona. Isso ficou claríssimo no meu solo. Ali é uma relação direta que se dá naquele exato momento. [...] Você vê uma coisa ali que te hipnotiza (Tiche Viana, entrevista, grifo nosso).
\end{abstract}

O estado auto-perceptivo é o que propicia ao performer potencializar a "dramaturgia essencial". Por se tratar de um contexto expressivo, a partitura, o roteiro de ações, deve ser executada em aberto, pois precisa estar permeável às forças do espaço cênico e do ambiente da platéia. $\mathrm{O}$ aspecto intuitivo continua organizando os elementos mesmo quando da apresentação, atualizando a performance à vista do público, buscando a comunicação direta com este. A exacerbação desse estado tem um papel fundamental na percepção do espectador, já que no Teatro Essencial é mantido "o sistema de distância entre palco e platéia, pois nenhum se toca na carne, fisicamente, como acontece no chamado "happening". Num teatro que seja essencial, porém, a matéria do fenômeno é a energia de tornar palco e platéia uma unidade" (STOKLOS, 2001, p. 14).

Geralmente é utilizado o espaço de palco italiano nas apresentações de Teatro Essencial, o que condiciona o espectador a participar preponderantemente com o seu olhar, caracterizando assim uma relação estética com a cena:

O Olho bem acurado recebia algumas informações residuais de seu corpo abandonado (a cinestesia da gravidade, do movimento, etc). Os outros sentidos do espectador, sempre em estado bruto, eram impregnados com algumas das percepções precisas do Olho. O Olho comanda o movimento do corpo para lhe dar informações - o corpo torna-se um coletor de dados. - Há um tráfego intenso 
nos dois sentidos dessa rodovia sensorial - entre a sensação conceituada e o conceito efetivado. Nessa aproximação instável encontra-se a origem dos cenários de percepção, performance e Body Art (O'DOHERTY, 2002, p. 54, grifo do autor).

Como conseqüência dessa relação espacial distanciada, a mobilização do espectador pelo "performer essencial" só pode ser feita pelos sentidos visual e auditivo. Porém, metaforicamente, esse contato deve ser similar ao tato, de conseguir provocar, por meio dos dois outros sentidos, sensações concernentes a esse último. O público deve ser tomado, alavancado das suas poltronas, acionado para o gesto transformador. $\mathrm{O}$ deslocamento espacial do performer é o provocador das devidas sensações nos corpos passivamente abandonados nos assentos da platéia:

Ela é muito forte, ela é muito interessante. A Denise é um fogo [...] uma força interior [...] é o Teatro Essencial... Você fechou o olho, você lembra do espetáculo, é ela em cena! E o que ela faz é que faz você se mover por dentro. O discurso dela faz você ir para dentro de você, lembrar de coisas, se emocionar... (Eduardo Coutinho, entrevista).

Antonio Abujamra e Gianni Ratto foram os dois professores convidados para as aulas de direção, cujo objetivo era orientar, pois a autoria é uma das competências relativas ao fazer do "performer essencial", o que investia cada aluno de um processo próprio de auto-direção de seu solo:

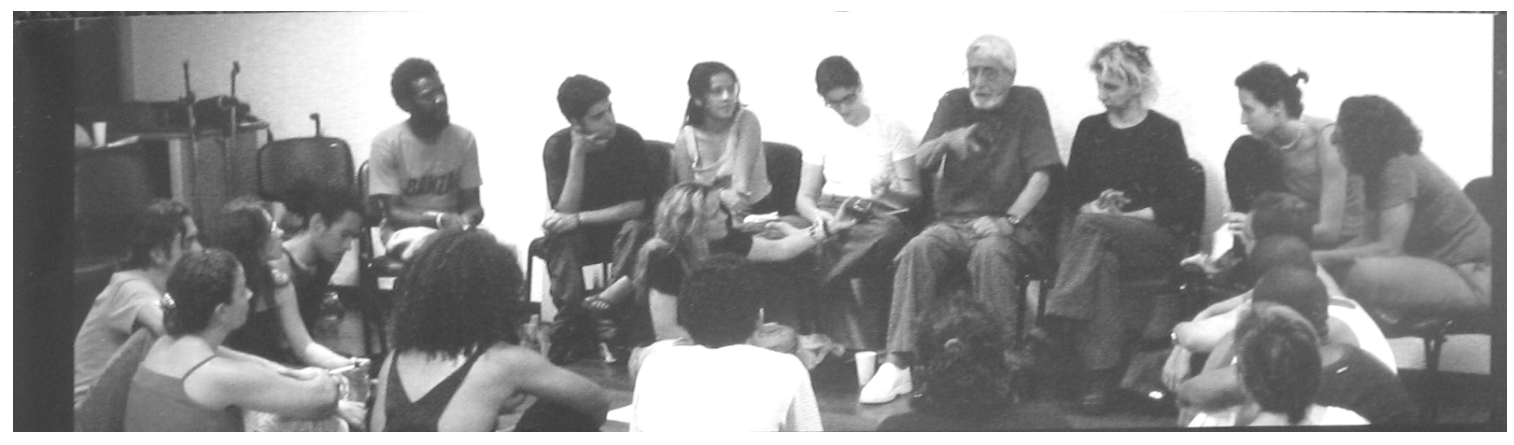

Pro Gianni a gente sempre mostrava... Ele dizia que hoje, por exemplo, ele não dita tanto as regras pro ator assim [...] O espaço é dele! O diretor tem que ficar quieto! Não tem que falar muito, ele tem que ver esse ator, o que é melhor pra ele [...] O ator tem sim que ter autonomia, ali, do espaço. Ele dizia que a palavra diretor deveria ser coordenador, assistente, um cara que ajude o ator a saber que o lugar dele é aquele, potencializar isso. (Jô Rodrigues, entrevista). 
Além dos professores responsáveis pelas aulas de direção, Stoklos realizava um diálogo semelhante ao estabelecido com as aulas Luiz Fuganti, fazendo um trabalho individual com cada atuante, desempenhando um papel "mais de orientadora, justamente porque ela sentia que às vezes vinha com tanta verdade, [que] ela tinha medo de por a mão e que a gente ficasse ofendido ou frustrado" (Simone Faro, entrevista). Para aqueles que compreenderam a dinâmica, quase maiêutica, dos procedimentos empregados na orientação, estabelecia-se mais nitidamente esse lugar ocupado pelo performer na hierarquia pressuposta para o Teatro Essencial, onde todos os questionamentos e decisões partem da sua figura. Na estruturação do seu solo, o aluno também era confrontado com questões relativas a um dos pensamentos norteadores da auto-direção, ou seja, a opção pela essencialidade na encenação:

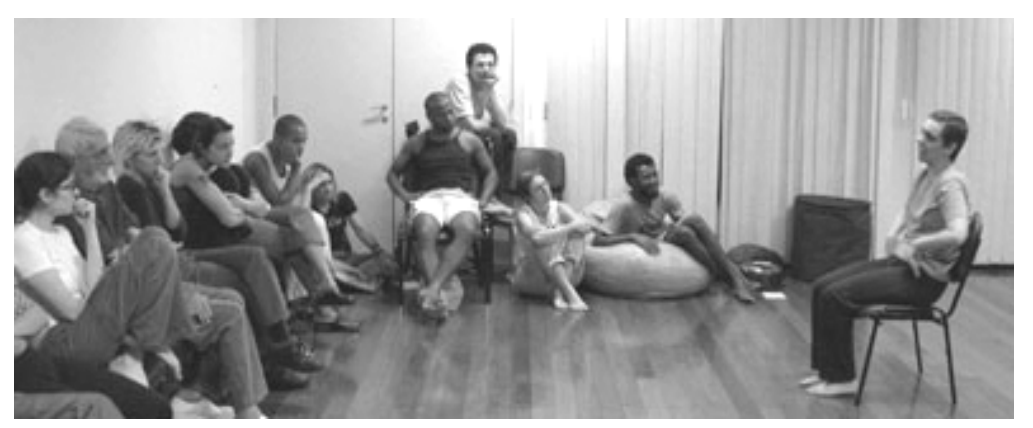

[...] ela perguntava sempre por quê: "Por que isso? Por que você vai lá?..." Tudo tem um porquê. Com ela não tinha essa coisa de: "Ah, porque eu quis!” Não! "Mas, o que te levou a andar até lá trás? Tem um movimento que te leva até lá?" [...] "Música, por que você escolheu essa música? Quê que essa cadeira, por exemplo, tá fazendo aí? Você vai usar essa cadeira? Vai ter um movimento? Tem alguma coisa a trabalhar com ela? Ela vai ser o que aí?" Os porquês eram assim... Sim, pode ter uma cadeira; eu por exemplo tinha um puff e um tambor. Legal, você usa o seu puff? A relação com ele, não deixar ele ali, se tinha algum objeto ele fazia parte de você, não era decorando (Jô Rodrigues, entrevista, grifo nosso).

Pela sua síntese, a "cena essencial" investe os poucos objetos presentes de um grande poder de significação, assumindo a função interlocutora das ações do "performer essencial". A opção, a disposição e o uso desses elementos concorrem para que a encenação ganhe o peso simbólico necessário à temática escolhida. Os conteúdos pessoais e autobiográficos precisam estabelecer correspondência com a organização cênica escolhida. É o pensamento do "performer essencial" que engendra os discursos, as ações, os artefatos 
cênicos, a musicalidade, as trajetórias espaciais. Era condição basilar, então, que cada aluno na formalização espetacular do seu solo estivesse bastante afinado com essa dinâmica:

\begin{abstract}
Denise falava muito isso: "O que você precisa dizer?", "O que é muito importante pra você por pra fora, pra você expressar?" [...] Não era uma coisa: "Ah, vou pensar o que é importante pra mim!" [...] Ela falava uma coisa muito importante: "Se é seu, se vem de você, é bom! Acredita!" Então era isso: "Deixa vir de você! Põe pra fora aquilo que é seu! Porque se é seu é essencial, é maravilhoso, e você acredita porque é você! É seu! É seu! É de verdade? Você acredita? Então não tem como dar errado!" A gente começou a perceber isso com o tempo, se aprofundando, se permitindo (Simone Faro, entrevista).
\end{abstract}

A idéia de Stoklos sobre esse estado criador alinha-se às correntes contemporâneas decorrente das teorias e pesquisas de grandes renovadores do teatro do século $\mathrm{XX}$, de entrega às emoções em vez de contê-las, tais como Artaud e Grotowski, "descobridores de subterrâneos freudianos [que] quiseram remontar às fontes do instinto e liberar as forças emocionais" (ASLAN, 1994, p. 251).

$\mathrm{O}$ ator, atleta do coração para Artaud ${ }^{13}$, ou santo para Grotowski ${ }^{14}$, deve ser aquele capaz de empreender uma busca em si mesmo de uma autenticidade e de revelar, nas ações do seu corpo, a manifestação direta e sem intermediações das vibrações mais profundas do seu espírito. Alguns exercícios aplicados se aproximam muito da via negativa proposta por Grotowski, de eliminar as travas e bloqueios do ator para diminuir o tempo de resposta entre o surgimento de um impulso e sua realização exterior.

Apesar da receptividade entusiasmada do público, aos solos que foram apresentados como resultado final do processo, foi unânime na avaliação dos participantes de que o tempo foi curto para se alcançar o resultado desejado. Para alguns, o processo se afigurou como uma iniciação aos princípios do Teatro Essencial, no qual cada atuante teve a oportunidade de acesso a um entendimento propositivo do que é atuar segundo as diretrizes práticas e teóricas do fazer teatral de Denise Stoklos :

Pra ser bem sincero, eu acho que "performer essencial" é a Denise Stoklos. E quem queira ser "performer essencial" talvez esteja no caminho errado! [...] Eu espero que os estudantes que participaram desse projeto tenham o senso crítico de

\footnotetext{
${ }^{13}$ Antonin Artaud (1896-1948), escritor, poeta, ator e diretor de teatro francês. Criador do Teatro da Crueldade.

${ }^{14}$ Jerzi Grotowski (1933-1999), diretor e fundador do Teatro Laboratório de Wroclaw na Polônia e criador do Teatro Pobre.
} 
perceber que cada um tem uma trajetória e que desenvolvam uma própria [...] Acho que ali foi um lugar onde você teve a oportunidade de se desenvolver, de crescer, de se questionar, mas desenvolva o seu próprio caminho, dê o seu próprio nome pra sua própria coisa. (Ricardo Napoleão, entrevista).

O caráter experimental do projeto Solos do Brasil mereceria passar por um balanço final com o corpo de professores e alunos para uma aferição dos acertos e erros. Como se tratava de uma prática artístico-pedagógica ainda não consolidada, era de fundamental importância a reflexão em conjunto dos envolvidos para definir os novos caminhos. Não fez parte do planejamento esse tipo de ação, em nenhuma fase do processo. E não há, até o momento, informações que indiquem a retomada das atividades.

Alguns dos alunos participantes continuam apresentando os seus solos, pesquisando e desenvolvendo as competências adquiridas, mas sem uma orientação, o que aponta para uma tendência de diluição dos princípios dentro das suas práticas pessoais:

\begin{abstract}
Mas, tudo o que eu recolhi ali foi e tem sido muito rico no meu trabalho [...] A sensação que eu tenho é que eu saio de lá com pistas, não saio de lá vazia, nem igual como entrei. Mas eu não posso dizer que saio de lá mais "performer essencial". Mas esse material e este pensamento me ajudam a vasculhar o que é essa questão, esse essencial, que eu acho que é atrelado à criação, e à obra, e trago pro teatro que eu faço. Então há influência? Há influência...

Acho que quem mais se beneficiou do trabalho eram as pessoas que não estavam em formação, já tinham o seu teatro, já tinham seu modo de fazer, já sabiam o que queriam de alguma maneira. Essas pessoas beberam na fonte e transformaram. Pra quem estava começando ou buscando ali uma semente muito determinante de um fazer, faltou metodologia. Ou faltou alguém que pudesse traduzir melhor essa relação de aprendizado (Tiche Viana, entrevista).
\end{abstract}

Experimentou-se para a formação do "performer essencial" no projeto Solos do Brasil uma estrutura que apontava para três caminhos: a expansão do contexto pessoal, o desenvolvimento das habilidades físicas e a exacerbação do estado de auto-percepção. Apesar desses três pilares serem entendidos como fundantes da atuação no Teatro Essencial, percebe-se que houve uma hierarquização do corpo docente que indica a relevância de um sobre o outro.

Com mais da metade dos professores encarregados de trabalhar o aspecto corporal, intui-se que o desenvolvimento da corporeidade para o "performer essencial" deva ser um fator preponderante para sua formação. O aspecto vocal foi o mais negligenciado, se tratando apenas do trabalho convencional de canto e não dos processos de "coreografia da 
palavra", tão significativos para a "cena essencial". O aspecto intuitivo, apesar de contar com um professor de teoria, muito competente nos direcionamentos que empreendeu, tinha um apoio na área prática que auxiliava o aprofundamento das questões debatidas em sua disciplina.

Basicamente, um ponto de confluência para todas as disciplinas foi o estímulo à expressividade pessoal do atuante, seja numa dinâmica da aula de dança, ou na apresentação de uma passagem do seu solo na aula de direção. Claramente há uma indicação que sempre se objetivou a autonomia das decisões do aluno, ou seja, um exercício da autoria da sua atuação solista.

Verifica-se assim que havia um pensamento metodológico com uma meta específica. Os princípios necessários para a formação do "performer essencial” foram contemplados, tanto em caráter exploratório quanto formalizador. Contudo, não houve uma etapa de apreciação das conquistas e desacertos experimentados. Os caminhos foram abertos e buscam sua realização na continuidade das práticas pessoais dos alunos participantes. Resta agora saber quais serão os desdobramentos deste projeto e qual o próximo passo na formatação de um novo processo artístico-pedagógico para a formação do "performer essencial". 


\subsection{Solo Brasileiro II.}

Na avaliação de Denise Stoklos, a sua primeira experiência pedagógica de formação de "performers essenciais", encetada no projeto Solos do Brasil, não foi positiva. Na sua auto-crítica, ela reconhece as dificuldades da articulação entre procedimentos espetaculares e métodos pedagógicos, princípio necessário para a transmissão de conteúdos, possíveis de serem aplicáveis a diferentes indivíduos. Nas suas palavras: "não vejo ninguém ali que eu diga: “Oh, o cara tá fazendo Teatro Essencial!” Não, todo mundo já veio com o seu talento, com a sua experiência e saiu com o seu talento e a sua experiência" (STOKLOS, entrevista).

Como visto anteriormente, mesmo com um planejamento artístico-pedagógico e com objetivos muito claros, a principal fratura se encontrava na ausência do compartilhamento das experiências comuns e na reflexão sobre as mesmas, para que dinamicamente o processo reconfigurasse sua sistematização. Deslocando-se de uma estrutura escolástica, com aulas ministradas por um corpo docente, para uma relação mestre-aprendiz - que evoca a sua crença no autodidatismo como caminho de aprendizado -, Stoklos dispõe da seguinte maneira a sua nova proposta de formação:

\footnotetext{
Surgiu no Rio de Janeiro um cara que ia muito assistir os meus espetáculos, [...] a temporada quase inteira de trabalhos meus. Isso por muitos e muitos anos. E virou meu amigo! [...] Ele fez um trabalho agora que é legitimamente Teatro Essencial. O nome dele é Marcos Americano. Este é o único realmente que está fazendo Teatro Essencial, exatamente nos preceitos que eu faço o meu, e, evidentemente, de acordo com o próprio preceito, é cooompletamente diferente do que eu faço! Porque cada um é único. Mas o preceito dele é o mesmo, [...] são todos com caráter ético de desenvolver as pessoas pra lutarem por seus desenvolvimentos, portanto serem revolucionárias, no sentido de não acreditar nas coisas que estão [...] (STOKLOS, entrevista).
}

Em vez de buscar as condições necessárias para os ajustes no plano artísticopedagógico aplicado no projeto Solos do Brasil, credita-se à obra cênica o papel instrumentalizador na formação do "performer essencial". Se antes a tentativa era de separar a professora da atriz, ela agora observa o potencial pedagógico das suas produções. 
Ela se assemelha assim ao artesão, cujos aprendizes constroem o seu saber na experiência imediata da observação da prática do mestre.

Marcos Americano, ator formado pela CAL (Casa de Artes de Laranjeiras - RJ), dedica, dos seus quase 30 anos de carreira, pelo menos dois terços ao Teatro Essencial de Denise Stoklos. Além de Stoklos, admite que a outra influência artística em sua vida foi o ator Rubens Corrêa, falecido em 1996, responsável por sua decisão de fazer teatro, quando assistiu ao ator interpretando Prometeu Acorrentado de Ésquilo em 1979. Será o mesmo Rubens que o dirigirá mais tarde na peça Sonho de Strindberg - "ele dizia, nós passamos um ano ensaiando, que o trabalho em que ele estava melhor como ator, em que ele tinha atingido, que chegou lá, foi Diário de um Louco de Gogol” (Marcos Americano, entrevista).

Desejoso de continuar seguindo os passos do mestre, após sua morte, ele resolveu também montar Diário de um Louco. Contudo, tão intensamente envolvido estava, naquele momento, com o seu outro grande mito, que Diário de um Louco foi se transformando em Dia dos Loucos, solo reconhecido por Stoklos como representante genuíno do Teatro Essencial.

Esses fatos da trajetória de vida de Marcos Americano, discorridos de forma tão banal, e até mesmo mexeriqueira, ganham uma outra dimensão ao ser analisados de um outro ponto de vista. Segundo ele, o seu primeiro contato com o trabalho de Stoklos foi quando a assistiu, no ano de 1986, em Um Orgasmo Adulto Escapa do Zoológico, e descreve da seguinte maneira o impacto: "pra mim foi uma aula imensa, foi assim... dois anos de escola de teatro, três anos, que eu aprendi ali naquele espetáculo [...] Então comecei a me aproximar de Denise, assim,... como um mito!” (Marcos Americano, entrevista).

Seguindo pelo caminho da observação, da proximidade, da escuta atenta, da leitura dos textos, e por que não dizer da repetição, da apropriação, da imitação, que faz parte da relação que qualquer discípulo mantém com o seu mestre, ao longo de 20 nos, os princípios do Teatro Essencial foram sendo assimilados. A sua forma de aprendizado nos traz um primeiro dado diferenciador da experiência do projeto Solos do Brasil: o tempo, que na avaliação final dos professores foi um fator de peso na aquisição das competências: "eu sinto que o processo final, ele começou a esboçar um início, teria muito que fazer, teria que ter uma continuidade" (Luiz Fuganti, entrevista). 
Como um mito mesmo! [...] Obrigado por você ter me ensinado tanta coisa! Ter me mostrado tanta coisa que eu não sabia nem que eu tava aprendendo ainda! [...] E passei a ver que era um teatro que eu queria fazer! E comecei a acompanhar os trabalhos da Denise, daí em diante eu vim acompanhando as peças quando ela vinha ao Rio, [...] cada vez aprendendo mais e admirando mais. E passei... não mais como um espectador: eu virei um seguidor! (Marcos Americano, entrevista, grifo nosso).

A percepção posterior de que, no contato com o espetáculo, o processo de aprendizagem já estava sendo efetuado, traz o mesmo tipo de apreciação feita por Stoklos das suas idas ao circo e ao cinema, na cidade de Irati, quando da sua infância. Repete-se a crença no autodidatismo expressa por ela, da orientação e seleção intuitiva que leva a uma construção pessoal e individualizada de um fazer próprio.

Na sede de cultuar o seu ídolo, o fã realiza uma atitude de apropriação de trejeitos, aparência, discursos e objetos na qual é possível reconhecer o processo de desumanização e mitificação sofrido pela pessoa que é objeto de adoração. No fetichismo, na imitação do comportamento, na tentativa de fazer parte, de amalgamar-se ao ser idolatrado, revela-se uma ação performativa:

[...] o processo de apropriação [...] é baseado no pressuposto de que uma parte pode conter o todo, que a arte, por exemplo, pode conter vida. Mas a única forma de uma parte conter o todo é por reflexão, como um espelho que pode refletir uma sala inteira, ou por ilação, dedução, como subentender, por meio do mapa de uma cidade, o país que o cerca. Quer dizer, o processo de apropriação pode recompor o universo inteiro no plano da sombra ou da reflexão, manifestando assim o seu imenso poder (MCEVILLEY, 1985, p. 290, tradução nossa).

A apropriação é um processo que pressupõe que uma parte pode conter o todo e a partir dessa parte é possível recompor o mundo ao qual ela pertence. Contudo, dependendo em que contexto essa parte é inserida, ela pode sofrer uma agregação de valores pertinentes ao espaço onde foi introduzida. Conseqüentemente, ela projeta sobre o mundo ao qual se referencia essa transmutação. Podemos encontrar um exemplo claro deste tipo de ação no contexto religioso, que ao se apropriar de objetos do cotidiano, esses transferem para o diaa-dia do fiel o poder de sacralização.

Na Performance, desde que Marcel Duchamp introduziu o ready-made, a roda de bicicleta, no ambiente da galeria, afirmando uma tendência que já vinha dando mostras 
pelos movimentos vanguardistas anteriores, a apropriação atingiu um grau de complexidade ainda maior:

\begin{abstract}
Nas artes visuais a questão sempre pareceu fácil, desde que o pintor, ou o escultor, ou o fotógrafo tradicionalmente criavam objetos fora de si mesmos. Mas o uso cada vez maior da apropriação tem dissolvido tal concepção, e na Performance, assim como na dança, o agente e a atividade freqüentemente parecem inseparáveis. Nos últimos vinte anos, vários artistas performáticos (James Lee Byars, Chris Burden, Linda Montano, e outros) levaram esta mudança de categoria ou rotação semântica ao seu limite, ao instalarem-se dentro de galerias e viverem nelas por longos períodos como performance. Nesta situação, mesmo os detalhes mais insignificantes do cotidiano são temporariamente distanciados e estranhados - isto é, transformados em arte - pela sobreposição de uma nova categoria que altera o foco cognitivo de ambos, do performer e do espectador (MCEVILLEY, 1985, p. 290-291, grifo nosso, tradução nossa).
\end{abstract}

O performer, ao exercer o poder de nomeação e validação que pode transformar tudo e todos em obra de arte, transfere também para si mesmo a idéia de obra, borrando as fronteiras entre objeto e artista. A arte passa a ser então uma atitude, uma ação do artista para com os objetos - inclusive consigo mesmo -, ao se apropriar dos mesmos e inseri-los no espaço artístico, sendo impossível não deixar de perceber que "tal gesto está repleto de estranhas inter-relações entre formas artísticas e religiosas, assim como o pedestal sempre foi uma variante do altar" (MCEVILLEY, 1985, p. 290, tradução nossa). O artista sacraliza a si mesmo ao introduzir o seu corpo, as suas imagens, a sua ação, nos domínios da arte, tornando-se assim um ser incomum, o que o leva a ocupar o mesmo patamar dos mártires e santos da Igreja Católica, ou dos monges budistas, ou de vários outros exemplos de pessoas em contextos religiosos que procuram perceber e praticar as suas ações cotidianas como manifestações sagradas de uma consciência superior.

\footnotetext{
A arte da apropriação em geral (e a Vow Art em particular) está baseada numa estética de escolha e sugestão ao invés de concepção e manufatura. $\underline{A}$ sensibilidade pessoal está afinada para a seleção da área do universo a ser apropriada, e com frequiência, profundamente caracterizada pelo voto comprometido consigo mesmo. O rigor com o qual o voto é mantido é, então, como um ofício devotado para a perfeição da forma (MCEVILLEY, 1985: 290291, grifo nosso, tradução nossa).
}

$\mathrm{Na}$ ação do "performer essencial", a manutenção constante do estado de autopercepção, que faz parte do aspecto intuitivo, auxilia no processo de apropriação de 
contextos que farão parte de sua dramaturgia espetacular, respondendo também pelo trânsito de informações que alimentam a organização do seu roteiro ou partitura cênica.

Ao que parece, consciente ou não, Marcos Americano na sua atitude de fã inveterado avizinha-se dos noviços em processo de iniciação que são orientados a se concentrar em determinadas práticas a fim de que, metódica e sistematicamente, alcancem, por meio da imitação da forma, uma experiência espiritual superior. Como no Japão, onde as artes, tais como a pintura, arranjos florais, lutas, música, teatro etc., têm no Zen-budismo a sua raiz comum. E o Zen também se faz presente no cotidiano das pessoas, não ocorrendo separação entre vida e arte. $\mathrm{O}$ ator oriental aprende o seu ofício seguindo o mesmo caminho do monge que oficia a cerimônia religiosa, ou seja, "a forma é o caminho para a harmonia e para a integração, uma espécie de oração" (AZEVEDO, 2002, p. 133).

Os artistas têm se valido da apropriação para inserir no espaço da arte conteúdos religiosos, políticos, filosóficos, autobiográficos etc., para que possam operar esses objetos com mais liberdade do que se estivessem em seus contextos originais:

\footnotetext{
Quando as sociedades aumentam sua demanda por ordem interna, o antigo papel xamânico, com a sua inassimilável combinação de poder e liberdade, é disseminado no interior de profissões especialmente mais maleáveis; em nossa sociedade, o médico, o poeta, o artista etc., cada um herdou um pedaço do manto do xamã. Iniciado com o período Romântico, uma tentativa foi reconstituir algo como a plenitude do papel xamânico dentro do domínio da arte; os poetas estavam aptos para conferir à experiência artística os poderes de cura e transcendência (MCEVILLEY, 1985, p. 290-291, tradução nossa).
}

Stoklos, ao se apropriar de fatos e personagens da história, também realiza esse tipo de operação, incorporando em si mesma "a liberdade e os poderes xamânicos", dando voz e manifestando os anseios da coletividade que clamam por justiça. Ela se torna esse indivíduo acima do bem e do mal, encarando o seu trabalho como social ou terapêutico, oferecendo ao espectador uma chance de experienciar criticamente e de rever suas crenças e certezas sobre determinada situação no espaço libertário da arte.

Acho que esse teatro que a gente faz, que eu faço, que a Denise faz, sobretudo que Denise faz, é um teatro necessário pro ser humano! Precisaria de um teatro de cinco mil lugares, pra ter sessões diárias [...] para as pessoas terem uma nova leitura da sociedade, das suas próprias vidas, pra gente ajudar a transformar, pra melhorar o planeta, a sociedade como um todo [...] (Marcos Americano, entrevista). 
O poder de libertação que o espaço da arte, assim como o da religião, projeta sobre o mundo por meio do objeto apropriado, e transforma o artista num ente que caminha ao lado do sacerdote, que está sempre com a sua atenção voltada para as pressões sociais que buscam um lugar de deságüe e de purificação. O seu investimento em si na preparação de um instrumental que capte, que absorva, como um totem, as vibrações que pairam no seu meio, requisitam dele procedimentos de sensibilização e de capacitação na "condução do espetáculo-ritual, valorizando a live art, a arte que está acontecendo ao vivo, no instante presente" (COHEN, 1989: 105).

$\mathrm{Na}$ sua longa trajetória de observação, Marcos Americano foi incorporando o fazer de Stoklos, e quando decidiu criar o seu solo Dia dos Loucos, ele já compreendia, por exemplo, a importância da autobiografia no processo de construção espetacular do Teatro Essencial:

Denise diz que os espetáculos dela são fruto de uma longa gestação, vai gestando ao longo de anos pra depois de repente sair. Então fui fazendo, fui criando, foram acontecendo transformações na minha vida, meu filho nasceu, eu me separei da mãe do meu filho, eu me casei de novo... Então foram vários acontecimentos na minha vida que foram acalentando junto com aquela fornalha que estava lá dentro [...] E aí foram cinco anos, entre idas e vindas, foram cinco anos de feitura, de gestação (Marcos Americano, entrevista).

No projeto Solos do Brasil, a transmissão dos princípios do Teatro Essencial foi ministrada por meio de exercícios técnicos, explanações teóricas e práticas orientadas. A junção objeto/artista dificulta muito desassociar Denise Stoklos e Teatro Essencial, e conseqüentemente na passagem dos ensinamentos algo se perdeu. No caso de Marcos Americano há o que poderíamos chamar de uma "técnica" de cultivar em si um ser "Denise Stoklos”. Duas questões então se fazem presentes: a solução é o caminho traçado por ele, isto é, a atitude do aprendiz, do iniciado, do noviço? E, se faltou tempo de maturação aos alunos do projeto Solos do Brasil, é possível aos que se mantiveram apresentando os seus solos alcançar o resultado esperado?

Uma coisa da base do Teatro Essencial, por exemplo, é trabalhar as diferentes potencialidades da sua voz, uma coisa que eu aprendi a trabalhar com o tempo [...] com essas apresentações seguidas, que eu mesmo produzo [...]

Um belo dia eu estava lá no Piauí, fazendo uma apresentação no Teatro Municipal, que é imenso, e no meio da peça eu reparei, eu me vi sendo ouvido. E me perguntei: “Quando será que se deu isso?’[...] 
Não foi o Caio Ferraz que colocou isso. Caio Ferraz dava canto, e muito bem dado. Isso talvez tenha sido colocado de maneira vaga, nos exercícios [...] Certamente Denise falou sobre isso... mas não se trabalhou isso... Eu sei, quando estou fazendo a minha peça, o que é vencer o silêncio, mas é difícil explicar tecnicamente (Vinicius Piedade, entrevista, grifo nosso).

$\mathrm{O}$ aspecto intuitivo novamente se faz presente na afinação dos aspectos corporal e vocal. É certo que Vinicius Piedade - e outros ex-alunos que continuam buscando e se desenvolvendo - vai incorporar o aprendizado adquirido às suas dinâmicas de trabalho, munido das teorias e rudimentos técnicos adquiridos nas aulas, durante a sua permanência no projeto. Todavia, sem o acompanhamento de Stoklos é bem provável que o seu fazer venha a se tornar uma releitura dos princípios que ela codificou, consecutindo num outro Teatro Essencial que carregará a marca pessoal de Vinicius Piedade.

Os dois caminhos para a formação do "performer essencial" apontam o tempo de maturação como preponderante de compreensão e execução do fazer teatral. A diferença entre as duas propostas é sobretudo vetorial: no Solos do Brasil o domínio da forma seria alcançado pela conscientização das partes que o constituem, no caso de Americano, é pela imitação da forma que se terá acesso ao conteúdo.

Há uma diferença estrutural também na hierarquização dos princípios, que revela-se no relato a respeito das oficinas ministradas sobre Teatro Essencial:

\footnotetext{
A minha oficina [...] Nós conversamos muito sobre coisas lindas e terríveis do ser humano [...] eu trabalho muito o despertar da consciência, eu busco muito a consciência crítica de cada um.

Então nós mergulhamos em questões, em dores passadas de cada um [...] e aí nós partimos prum trabalho individual [...] A idéia é de cada um ter um "work in progress" não só durante a oficina, como também depois, até anos e anos depois, de ir descobrindo um assunto profundo, de importância essencial pro seu ser artístico e daí ele vai e leva à cena.

Se ele for um bom capoeirista, ele vai usar capoeira; se for como Denise trabalha a mímica; eu trabalho o fôlego, a coisa física; se for uma bailarina, ela vai apresentar um balé... O que vai emanar é a indignação, é o desejo de transformação, é o questionamento ao poder, a ordem social, ao status quo, ao establishment. (Marcos Americano, entrevista).
}

Vemos que o aspecto intuitivo ganha a primazia na formação, secundado pelo corporal, não sendo feita qualquer menção ao vocal. O desenvolvimento das habilidades físicas, uma demanda bastante valorizada no projeto Solos do Brasil, nessa estrutura não é vista como um fator que asseguraria a potência do discurso cênico. A importância, por 
exemplo, da mímica como base técnica é mitigada em função de qualquer habilidade que possibilite o uso do corpo de uma forma plástica em cena. A necessidade da estimulação da autopercepção e a manifestação expressiva de conteúdos urgentes continuam sendo um ponto de contato entre os dois processos de formação.

O solo Dia dos Loucos reúne os princípios necessários para ser considerado um "solo essencial". Há um mínimo de recursos cênicos: não são usados objetos de cena e nem cenário, somente efeitos de sonoplastia e variações de luz; o figurino é bastante simples e despojado. O espetáculo é completamente sustentado pela atuação do performer, que por meio de depoimentos pessoais informa ao público sobre dados estatísticos, reminiscências de infância, crenças religiosas, questões existencias, fatos do cotidiano, características particulares:

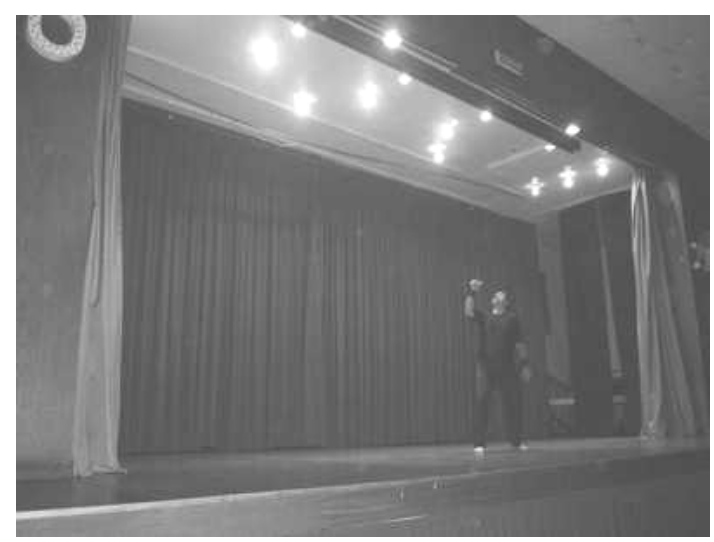

O ponto de partida do espetáculo foi uma pesquisa da Unicef sobre gastos exorbitantes com armamentos, dos quais uma mínima fração seria suficiente para aplacar a fome mundial. O performer assume um tom de indignação ao relatar esse e outros acontecimentos que o deixam "louco" - originando assim o nome da peça -, e dividindo com a platéia as suas reflexões e os seus desabafos, conclamando-a a uma conscientização crítica: 

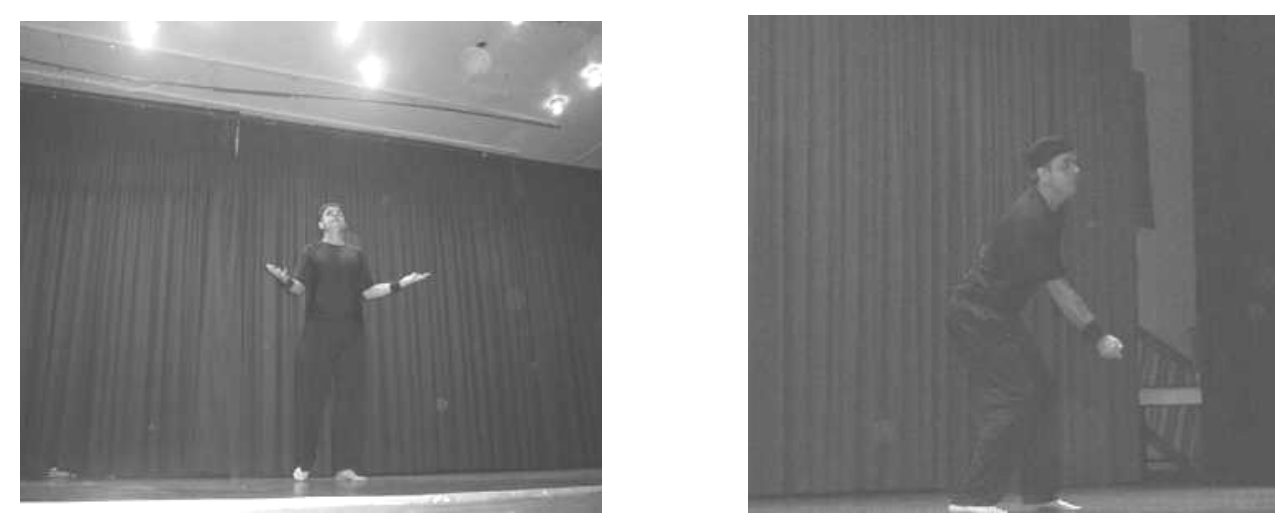

Os três aspectos necessários ao "performer essencial" para realizar o acontecimento cênico - corpo, voz, e intuição - estão presentes. Percebe-se nitidamente um pensamento organizador das aptidões físicas, concebendo variações rítmicas e espaciais, introduzindo quebras inesperadas na gestualidade e na fala. Contudo, as habilidades físicas não estão suficientemente potencializadas.

A reestruturação da hierarquia das competências experimentada aqui, com um peso maior no aspecto intuitivo do que nos outros dois, revela que apenas o emprego das habilidades corporais não é suficiente para alcançar o grau necessário de comunicação com o público. Como visto anteriormente, no projeto Solos do Brasil a relevância era para o desenvolvimento do aspecto corporal, com um estímulo bastante potente, mas em menor quantidade, do aspecto intuitivo, e pouco investimento no aspecto vocal. A crença atual, de que no processo de constituição do "performer essencial" não é tão significativo o apuro técnico dessas habilidades, cobra o seu preço na fragilidade da emissão do discurso cênico.

Os princípios foram empregados na construção do solo, o que atesta a eficácia do método intuitivo de aprendizagem, que pela observação atenta e dedicada, vai laboriosa e artesanalmente erigindo o saber. Todavia, nos relatos dos participantes do projeto também transparece o entendimento intelectivo das propostas e princípios do Teatro Essencial, que na continuidade das apresentações dos seus solos foram aprofundando ainda mais esse conhecimento.

Resta saber agora qual será o balanço que Stoklos fará futuramente dessas duas experiências e quais diretrizes serão traçadas por ela para conseguir a transmissão efetiva dos ensinamentos do seu teatro. Acreditamos que a reflexão sobre as duas propostas pode apontar os caminhos para uma "pedagogia essencial". 
Conclusão. 


\section{Conclusão}

A discussão acerca de uma práxis para o ator do século XXI ainda é arriscada pela proximidade entre o pesquisador e o objeto; contudo, a cena contemporânea, dada a sua complexidade estética, exige uma formação mais abrangente. $\mathrm{O}$ trabalho solo desenvolvido por Denise Stoklos com seu Teatro Essencial aponta algumas respostas e desafios a esta questão.

A crença de que a constituição de uma nova linguagem deve partir do emprego do potencial pessoal, imprime ao conteúdo autobiográfico uma importância ímpar na constituição do Teatro Essencial. Neste, como uma consciência atemporal, as memórias de "Irati" se fazem presentes, evocadas nas relações, no ambiente, no cotidiano, nas lúdicas explorações e nos desafios. A importância assumida pelos conteúdos pessoais e autobiográficos, combinados às questões de gênero e de identidade, é tão preponderante, que é impossível conjeturar qualquer espécie de apreciação sobre o Teatro Essencial sem levar em conta esses operadores. As temáticas manifestam-se em atendimento a estas solicitações, o que resulta numa permanente (re)apresentação de fixações, de mitologias particulares, de reminiscências e de obsessões.

O contexto brasileiro dos anos 70 constitui, na trajetória de Denise Stoklos, a exploração, a expansão e o amadurecimento das experimentações artísticas da infância e da adolescência. Já exibindo, na sua gestualidade física, traços de uma expressividade espetacular, as opções apontam para a busca de uma afinação do seu instrumental, pelas passagens que realizou com vários diretores e grupos, pelos estudos jornalísticos e sociológicos, pela técnica rigorosa da mímica e pelo processo elaborado em sua desconstrução.

O Manifesto do Teatro Essencial, que compila as suas propostas de forma mais direcionada, expõe suas memórias de infância, suas opções políticas, seus caminhos profissionais, enfim, o pano de fundo da busca de uma expressão artística que sintetiza uma história de vida. Ao invés de desprezar a bagagem "original", em detrimento da aquisição de novos conhecimentos, seu movimento foi o de justamente promover um refinamento no 
seu modo de operar, em busca de uma linguagem que procura ser o arauto das inquietações humanas.

A pessoa do atuante é o epicentro e dele partem todos os vetores que organizam a "cena essencial", e por mais que existam elementos cenográficos, textuais, sonoros, etc, o foco é sempre a dramaturgia concebida por ele, que organiza os aspectos corporais e vocais, que são únicos (ou seja, inerentes à corporeidade de cada "performer essencial"), no espaço teatral. Os eixos principais que articulam este fazer - corpo, voz e intuição - têm no trato com a gravidade o seu foco de exploração técnica e performativa. As proposições exigem esse novo "ator" - o "performer essencial" - um porta-voz de si mesmo que exibe no corpo, na voz e no pensamento o seu pertencimento a esta esfera de atuação. O rigor do convite exige uma atitude pesquisadora dos limites do seu aparato psicofísico e a sua expansão, já que a sobriedade cênica cobra-lhe a dilatação da sua presença.

A transmissão do conhecimento reunido, exercitado e experimentado durante algumas décadas por Stoklos, mostra alguns caminhos possíveis para um sistema de atuação pessoal. Anterior a qualquer instrumentalização técnica, a idiossincrasia é um fator basilar que necessita ser percebido, explorado e exacerbado, resultando num potencial que busca a formalização espetacular. $\mathrm{O}$ aspecto intuitivo é responsável por articular dinamicamente o intelectual e o emocional na organização dos elementos físicos, daí a relação feita com a dramaturgia, que aqui é vista como um pensamento, e não como a escrita de texto. A idéia é que o "performer essencial" busque uma articulação rítmica entre corpo e voz que estimule o público a percepções diferenciadas.

No desenvolvimento dos aspectos físicos podem ser escolhidas técnicas diversas, pois o importante é saber organizá-los, é dominar o processo de construir uma dramaturgia pessoal orientada pelos aspectos intuitivos, atendendo ao objetivo primordial da comunicação: a opinião e a reflexão críticas sobre o tema tratado, buscando a transformação do espectador.

A máxima do Teatro Essencial (isto é: resumir os elementos da encenação ao "performer essencial”, a um objeto e à iluminação) estabelece o diálogo cênico entre a potência das características físicas do espaço e o atuante, que dispõe do seu corpo, da sua voz e da sua intuição para a realização do acontecimento cênico. No controle do equilíbrio precário do corpo do ator é que se explicitam as relações entre esses dois parceiros de jogo: 
o ambiente cênico e o performer. Os temas recorrentes são transpostos metaforicamente para os objetos (e para a iluminação, conseqüentemente) e se tornam os interlocutores do "performer essencial", que ao manipulá-los expressa simbolicamente como o poder da força criativa de um único ser humano pode flexibilizar a rigidez do contexto em que está imerso.

A "dramaturgia essencial" se utiliza de justaposições, colagens, apropriações, citações e reproduções, organizando um roteiro ou partitura cênica que começa a ganhar urdidura nos ensaios e vai sendo modificada, como uma matéria flexível, no contato com a platéia. A dinâmica do processo imbrica-se com o cotidiano, não existindo separação entre arte e vida, levando o "performer essencial" a se manter num estado constante de autopercepção e assim conseguir captar os elementos que farão parte da dramaturgia espetacular.

Entendemos o grau de importância desta pesquisa pelos caminhos apontados para a estruturação de outros sistemas de atuação pessoal, pois no desenvolvimento do potencial idiossincrático, é certo que o resultado será uma linguagem única e particular. Esta pesquisa além de poder vir a contribuir para a formação profissional do ator, também referenda o papel significante para a história do teatro brasileiro do trabalho de ponta desenvolvido por Denise Stoklos. 
Fontes Consultadas 


\section{REFERÊNCIAS}

- Bibliografia:

ASLAN, Odette. O Ator no Século XX. São Paulo: Editora Perspectiva, 1994.

AZEVEDO, Sônia Machado. O Papel do Corpo no Corpo do Ator. São Paulo:

Perspectiva, 2002.

BARBA, Eugenio e SAVARESE, Nicola. A Arte Secreta do Ator - Dicionário de Antrolpologia Teatral. Campinas: Unicamp/Hucitec, 1995.

BONFITTO, Matteo. O Ator Compositor. São Paulo: Perspectiva, 2002.

BONNEY, Jo (ed). Extreme Exposure: An Anthology of Solo Performance Texts from the

Twentieth Century. New York: Theatre Communications Group, 2000.

COHEN, Renato. Performace como Linguagem: Criação de um Tempo - Espaço de Experimentação. São Paulo: Edusp / Perspectiva, 1989.

CRUZ, Denise Rollemberg. Exílio: entre raízes e radares. Rio de Janeiro: Record, 1999.

DAMASCENO, Leslie. The Gestural Art of Reclaiming Utopia: Denise Stoklos at Play with the Hysterical-Historical. in TAYLOR, Diana and Roselyn Costantino (ed.). Holy Terrors: Latin American Women Perform. Durham: Duke University Press, 2003, pp. 111143.

FELDENKRAIS, Moshe. Consciência pelo Movimento. São Paulo: Summus, 1977.

FERNANDES, Sílvia. Grupos Teatrais - Anos 70. Campinas: Ed. Unicamp, 2000.

GOLDBERG, RoseLee. A Arte da Performance: do Futurismo ao Presente. São Paulo: Martins Fontes, 2002.

LABAN, Rudolf. Domínio do Movimento. São Paulo: Summus, 1978.

LEVI, Clovis. Teatro Brasileiro - Um Panorama do Século XX. Rio de janeiro: Funarte, 1997.

MCEVILLEY, Thomas. Art in the Dark. in HERTZ, Richard (org.). Theories of Contemporary Art. New Jersey: Englewood Cliffs, Prentice-Hall, Inc., 1985, pp. 287-305.

O’DOHERTY, Brian. No Interior do Cubo Branco, a Ideologia do Espaço da Arte. São Paulo: Martins Fontes, 2002. 
PAVIS, Patrice. A Análise dos Espetáculos. São Paulo: Perspectiva, 2003.

Dicionário de Teatro. São Paulo: Perspectiva, 1999.

ROUBINE, Jean-Jacques. A Linguagem da Encenação Teatral (1880-1980). Rio de Janeiro: Zahar Editores S.A., 1982.

STOKLOS, Denise. Calendário da Pedra. SL, SN, 2001. . Teatro Essencial. SL, SN, 1992.

- Teses, Dissertações e Monografias:

GÓIS, Marcus Villa. Estrada de Sonhos: uma Contribuição Circense na Formação do Ator. Dissertação de Mestrado, Salvador, UFBA, 2005.

LOUIS, Luis. A Comunicação do Corpo na Mímica e no Teatro Físico. Dissertação de Mestrado, PUC/SP, 2005.

MOURA, Cristiane. Solidão Anárquica: Vocabulário da Atitude no Teatro essencial. Dissertação de Mestrado, Estudos do espetáculo, UNI-RIO, 1997.

PRADO, Fernando César. Delírio Solitário: A Autodireção no Trabalho Solo de Denise Stoklos. Monografia, Uberlândia, FAFICS-UFU, 2002.

- Artigos e Periódicos:

A ARTE DA GUERRA. Folha de São Paulo. São Paulo, 05 de janeiro de 2005, Ilustrada, p. E1.

BERNSTEIN, Ana. A Performance Solo e o Sujeito Autobiográfico. Revista Sala Preta, São Paulo, ECA-USP, nº 1, 2001.

CABAllero, Mara. O Talento da Mímica e o Poder da Palavra. Revista de Domingo, Rio de Janeiro, $n^{\circ}$ 505, v.10, jan. 1986, p. 12-3.

DENISE STOKLOS É PURA CONVICÇÃO. Folha Universitária - UNIBAN. S. Paulo, 21 a 26/08/06, p. 4.

DENISE, ATRIZ COMPLETA. Jornal da Tarde. São Paulo, 07/04/87, p. 18. 
GUSMÃO, Rita. O Ator Performático. Revista Performance, Cultura e Espetacularidade, Brasília: Universidade de Brasília, 2000.

KATZ, Helena. Denise Stoklos Inicia Curso da Arte Mímica. Folha de São Paulo. São Paulo, 09 de novembro de 1982, p. 37.

KATZ, Helena. A Mímica Contemporânea Segundo Denise Stoklos. Folha de São Paulo. São Paulo, 27 de setembro de 1983, p. 27.

MAGALDI, Sábato. A Mímica, no domínio perfeito e no humor de Denise Stoklos. Jornal da Tarde. São Paulo, 24 de Junho de 1981, p. 20.

MICHALSKI, Yan. Denise Stoklos, uma artista do gesto. Jornal do Brasil. Rio de Janeiro, 03 de Fevereiro de 1982, p. 2.

DENISE STOKLOS VAI DA MÍMICA À PANTOMIMA. Folha de São Paulo. São Paulo, 03 de agosto de 1982, p. 32.

LEHMAnN, Hans-Thyes. Teatro Pós-Dramático e Teatro Político. Revista Sala Preta, São Paulo, ECA-USP, n $^{\circ}$ 3, 2003.

NÉSPOLI, Beth. Três Décadas de Teatro Essencial. O Estado de S. Paulo. São Paulo, 16 de Março de 1999, Caderno 2, p. D 6.

ROMERO, Raul. De la Palabra a la Imagem. Revolución y Cultura, La Habana, nº 9, v.29, Set. 1987, p. 18-23.

STOKLOS FAZ STUART PARA AMERICANO VER. Jornal do Brasil. Rio de Janeiro, 05/03/87, caderno B, p. 7.

TEATRO ESSENCIAL DE DENISE STOKLOS INVESTE NA POESIA DE GERTRUDE STEIN. O Estado de S. Paulo. São Paulo, 05 de Julho de 2001, Caderno 2, p. D2.

TEATRO ESSENCIAL DE DENISE STOKLOS ANALISA O TEMPO. O Estado de $S$. Paulo. São Paulo, 17 de Agosto de 2001, Caderno 2, p. D16.

UM CORPO FLUTUA NO INCONSCIENTE. O Estado de São Paulo. São Paulo, 21 de Novembro de 1986, Caderno 2, p. 6.

- Vídeos:

PROGRAMA DO JÔ. TV Globo. São Paulo-SP, (60min), 17/03 /2007. 
- Documentos Eletrônicos:

RAMIREZ-CANCIO, Marlène. Vozes Dissonantes: Denise Stoklos Recovers Historical Memory (or, Who Does Stoklos Talk To? And How Do They Hear Her?). 2001. Disponível na World Wide Web:

http://hemi.nyu.edu/archive/studentwork/global/Marlene_site_DeniseStoklos_REV/ papervozes.html

SILVA, Grazielle Roberta Freitas, MACEDO, Kátia Nêyla de Freitas, REBOUÇAS, Cristiana Brasil de Almeida et al. Entrevista como técnica de pesquisa qualitativa. Online braz j nurs. [online]. abr. 2006, vol.5, no.2 [citado 15 Janeiro 2008], p.00-00. Disponível na World Wide Web:

$<$ http://www.portalbvsenf.eerp.usp.br/scielo.php?script=sci_arttext\&pid=S1676$42852006000200028 \& \operatorname{lng}=$ pt\&nrm=iso $>$. ISSN 1676-4285.

- Entrevistas:

2007: Com Denise Stoklos, Marcos Americano, Eduardo Coutinho, Ricardo Napoleão, Luiz Fuganti, Simone Faro, Tiche Viana, Vinícius Piedade e Jô Rodrigues. 


\section{BIBLIOGRAFIA CONSULTADA}

- Bibliografia:

ARGAN, Giulio Carlo. Arte Moderna. São Paulo: Editora Schwartz LTDA, 2004.

BARBA, Eugenio. A Canoa de Papel - Tratado de Antrolpologia Teatral. São Paulo: Hucitec, 1994.

BAUDRILLARD, Jean. O Sistema de Objetos. São Paulo: Perspectiva, 1973.

BRECHT, Bertolt. Estudos Sobre Teatro. Lisboa: Portugália, 1957.

BURNIER, Luís Otávio. A Arte de Ator: da Técnica à Representação. Campinas:

Unicamp, 2001.

CARLSON, Marvin. Teorias do Teatro. São Paulo: UNESP, 1997.

CASE, Sue-Ellen. Performing Feminisms: Feminist Critical Theory and Theatre. Baltimore: The Johns Hopkins University Press, 1990.

COHEN, Renato. Work in Progress na Cena Contemporânea. S. Paulo: Perspectiva, 1998.

EVERDELL, William. Os Primeiros Modernos. As Origens do Pensamento do Século XX. Rio de Janeiro/São Paulo: Editora Record, 2000.

FERRACINI, Renato. A Arte de não Interpretar como Poesia Corpórea do Ator. Campinas: Unicamp/Imesp, 2001.

GALIZIA, Luiz Roberto. Os Processos Criativos de Robert Wilson. São Paulo: Perspectiva, 1986.

GLUSBERG, Jorge. A Arte da Performance. São Paulo: Perspectiva, 1987.

GOLDBERG, RoseLee. Performance: Live Art since the 60s. London: Thames and Hudson, 1998.

GREINER, Christine. O Corpo. Pistas para Estudos Indisciplinares. São Paulo: Annablume, 2005. e AMORIM, Cláudia (org.). Leituras do Corpo. São Paulo: Annablume, 2003.

GROTOWSKI, Jerzy. Em Busca de um Teatro Pobre. Rio de Janeiro: Civilização Brasileira, 1987. 
HERTZ, Richard (org.). Theories of Contemporary Art. New Jersey: Englewood Cliffs, Prentice-Hall, Inc., 1985

KAISER, Wolfgang. O Grotesco. São Paulo: Perspectiva, 2003.

KRAUSS, Rosalind. Caminhos da Escultura Moderna. São Paulo: Martins Fontes,1998. The Originality of the Avant-Garde and Other Modernist Myths.

London: Mit Press, 1985.

LAKOFF, George e Johnson, Mark. Metáforas da Vida Cotidiana. São Paulo: Educ, 2002.

MC EVILLEY, Thomas. Sculpture in the Age of Doubt. New York: Allworth Press, 1999.

PAIVA, Salvyano Cavalcanti de. Viva o Rebolado!: Vida e Morte do Teatro de Revista Brasileiro. Rio de Janeiro: Nova Fronteira, 1991.

PALLOTTINI, Renata. Dramaturgia: Construção do Personagem. São Paulo: Ática, 1989. . Introdução à Dramaturgia. São Paulo: Ática, 1988.

PRADO, Décio de Almeida. O Teatro Brasileiro Moderno. São Paulo: Perspectiva, 2003.

PRÓCHNO, Caio César Souza Camargo. Corpo do Ator-Metamorfoses, Simulacros. São Paulo: Annablume, 1999.

ROMANO, Lúcia. O Teatro do Corpo Manifesto: Teatro Físico. São Paulo: Perspectiva, 2005.

RYNGAERT, Jean-Pierre. Introdução à Análise do Teatro. São Paulo: Martins Fontes, 1996.

SÁNCHEZ, José A. Dramaturgias de la Imagen. Cuenca: Ediciones de la Universidad de Castilla - La Mancha, 2002.

SHECHNER, Richard. Performance Theory. New York: Routledge, s/d.

SZONDI, Peter. Teoria do Drama Moderno [1880-1950]. São Paulo: Cosac \& Naify Edições, 2001.

STANISLÁVSKI, Constantin. El Método de Acciones Físicas. in El Evangelio de Stanislávski. México: Grupo Editorial Gaceta, 1990.

TOPORKOV, Vladimir. Las Acciones Físicas como Metodologia. in El Evangelio de Stanislávski. México: Grupo Editorial Gaceta, 1990.

VENEZIANO, Neide. O Teatro de Revista no Brasil - Dramaturgia e Convenções. Campinas: Unicamp, 1991. 
YOUNG, Jordan R. Acting Solo: The Art of One-Man Shows. Beverly Hills: Moonstone Press, 1989.

- Teses, Dissertações e Monografias:

BRÍCIO, Pedro. Denise Stoklos in Cena: Pensamento em Movimento. Dissertação de Mestrado, Teatro, UNI-RIO, 2001.

COSTA, Felisberto Sabino. A Poética do Ser e Não Ser - Procedimentos Dramatúrgicos do teatro de Animação. Tese de Doutorado, São Paulo, ECA-USP, 2000.

COUTINHO, Eduardo. O Mimo e a Mímica: Uma Contribuição para a Formação do Ator Brasileiro. Dissertação de Mestrado, São Paulo, ECA-USP, 1993.

LEOTE, Rosangella. O “Potencial Performático". Tese de Doutorado, São Paulo, ECAUSP, 2000.

SOBRAL, Suzy Capó. The Essential Theatre of Stoklos: An Alternative Perspective of Contemporary Brazilian Theatre. Dissertação de Mestrado, New York, NYC, 1992.

- Artigos e Periódicos:

GROTOWSKI, Jerzy. Revista Máscara. Año 4, 11/12, México.

TAYLOR, Diana. Denise Stoklos: The Politics of Decipherability. The Drama Review, New York, $n^{\circ} 2$, (Summer 2000), p. 7-29.

- Vídeo:

PROGRAMA RODA VIVA. TV Cultura. São Paulo-SP. (90min). 05/09/01. VHS. 
- Documentos Eletrônicos:

http://hemi.nyu.edu/archive/ram/calenderstone.ram

Video clip of Calendar of Stone, New York, July 2003, 7 min/256K.

http://hemi.nyu.edu/archive/ram/MariaStuardo.ram

Vídeo clip de Mary Stuart, Peru, verão de 2002

- Peças:

STOKLOS, Denise. Calendário da Pedra. SL, SN, 2001.

Des-Medéia. SL, SN, 1994.

. Mary Stuart. SL, SN, 1995.

500 Anos - um Fax de Denise Stoklos para Cristóvão Colombo.

SL, SN, 1992. 


\section{ANEXO}

Cronologia dos espetáculos de Denise Stoklos:

1968 Círculo na Lua, Lama na Rua

1969 A Semana

1970 Vejo o Sol

1971 Mar Doce Prisão

1973 Cadillac de Prata

1980 Denise Stoklos - One Woman Show

1982 Elis Regina

1983 Um Orgasmo Adulto Escapa do Zoológico

1986 Habeas Corpus

1987 Denise Stoklos in Mary Stuart

1988 Hamlet em Irati

1990 Casa

1992500 Anos - Um Fax de Denise Stoklos para Cristóvão Colombo

1993 Amanhã Será Tarde e Depois de Amanhã Nem Existe

1993 Jardim de Meteoros

1994 Nina Simone Sings For Us

1994 Des-Medéia

1995 Elogio

1996 Mais Pesado que o Ar/Santos Dumont

1997 Desobediência Civil

1999 Vozes Dissonantes

2000 Louise Bourgeois - Eu Faço, Eu Desfaço, Eu Refaço

2001 Calendário da Pedra

2004 Olhos Recém-Nascidos

2007 Cantadas

2007 Denise Stoklos em Teatro para Crianças 